Environmental Safety, Health, and Quality Directorate

\title{
FACILITY ENVIRONMENTAL VULNERABILITY ASSESSMENT
}

June 2001 


\section{DOCUMENT AVAILABILITY}

Reports produced after January 1, 1996, are generally available free via the U.S. Department of Energy (DOE) Information Bridge.

Web site http://www.osti.gov/bridge

Reports produced before January 1, 1996, may be purchased by members of the public from the following source.

National Technical Information Service

5285 Port Royal Road

Springfield, VA 22161

Telephone 703-605-6000 (1-800-553-6847)

TDD 703-487-4639

Fax 703-605-6900

E-mail info@ntis.fedworld.gov

Web site http://www.ntis.gov/support/ordernowabout.htm

Reports are available to DOE employees, DOE contractors, Energy Technology Data Exchange (ETDE) representatives, and International Nuclear Information System (INIS) representatives from the following source.

Office of Scientific and Technical Information

P.O. Box 62

Oak Ridge, TN 37831

Telephone 865-576-8401

Fax 865-576-5728

E-mail reports@adonis.osti.gov

Web site http://www.osti.gov/contact.html

This report was prepared as an account of work sponsored by an agency of the United States Government. Neither the United States Government nor any agency thereof, nor any of their employees, makes any warranty, express or implied, or assumes any legal liability or responsibility for the accuracy, completeness, or usefulness of any information, apparatus, product, or process disclosed, or represents that its use would not infringe privately owned rights. Reference herein to any specific commercial product, process, or service by trade name, trademark, manufacturer, or otherwise, does not necessarily constitute or imply its endorsement, recommendation, or favoring by the United States Government or any agency thereof. The views and opinions of authors expressed herein do not necessarily state or reflect those of the United States Government or any agency thereof. 
Environmental Safety, Health, and Quality Directorate

\section{FACILITY ENVIRONMENTAL VULNERABILITY ASSESSMENT}

June 2001

Prepared by

OAK RIDGE NATIONAL LABORATORY

Oak Ridge, Tennessee 37831-6285

managed by UT-BATTELLE, LLC

for the

U.S. DEPARTMENT OF ENERGY

under contract DE-AC05-00OR22725 



\section{Contents}

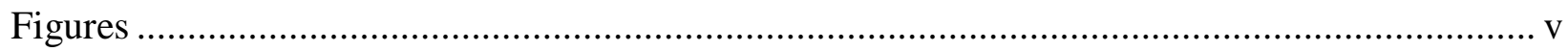

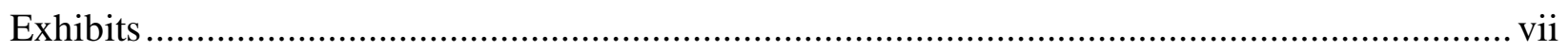

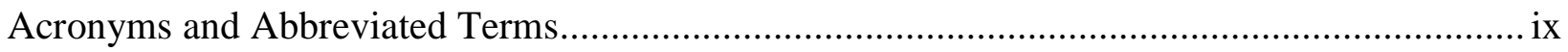

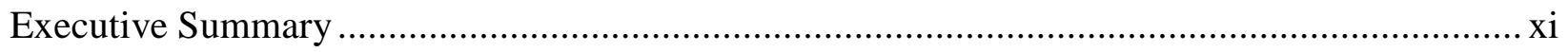

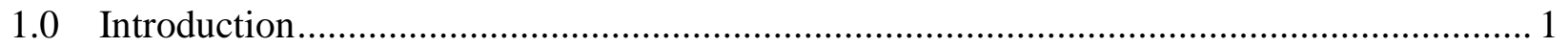

1.1 Purpose and Scope ...................................................................................... 1

1.2 Evaluation Process and Methodology ................................................................... 2

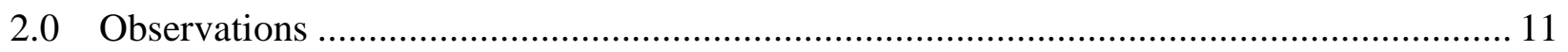

2.1 Programmatic Barrier Review .............................................................. 11

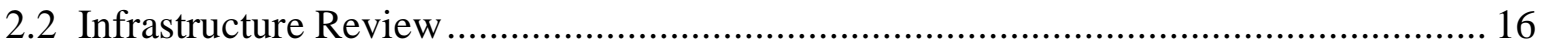

2.3 Past Vulnerability Reduction Initiatives ............................................................ 27

2.4 Current Vulnerability Reduction Initiatives...................................................... 28

2.5 Vulnerabilities Noted During Facility Assessments .......................................... 29

2.6 Are Any UT-Battelle Facilities Discharging Significant Amounts of

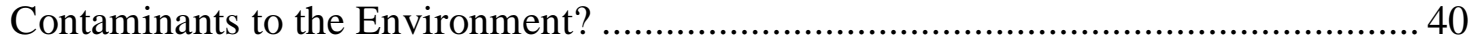

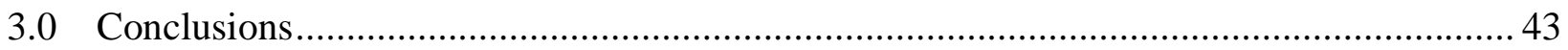

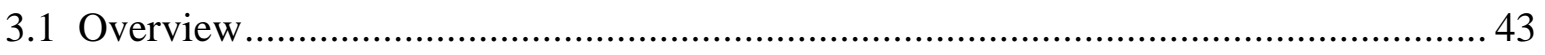

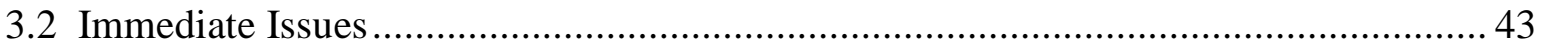

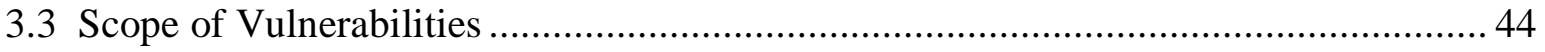

3.4 Control and Detection of Significant Releases ................................................ 44

3.5 Control and Detection of Chronic Small Releases .................................................. 44

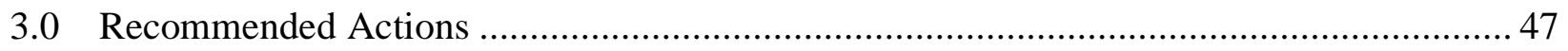

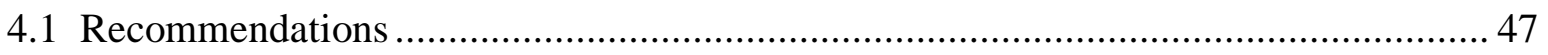

4.2 Near-Term Actions: 2 Years or Less to Implement ............................................. 47

4.3 Long-Term Actions: 2-10 Years to Implement ............................................... 47

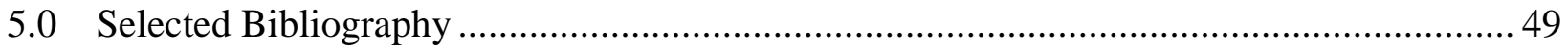





\section{Figures}

\section{Figure}

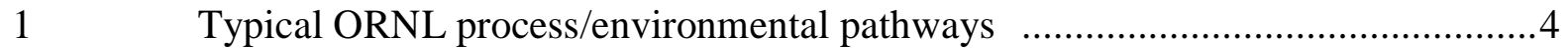

2 Environmental vulnerability assessment timeline ..........................................6

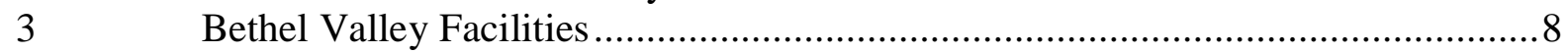

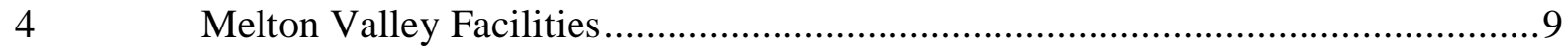

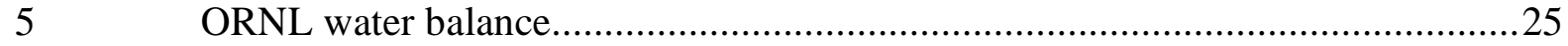





\section{Exhibits}

\section{Exhibit}

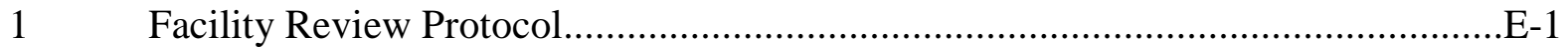

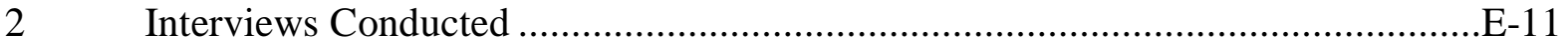

$3 \quad$ Vulnerability and Observation Summary ........................................................ 



\title{
Acronyms and Abbreviated Terms
}

\author{
Battelle Battelle Memorial Institute \\ BJC Bechtel Jacobs Company LLC \\ BNL Brookhaven National Laboratory \\ CERCLA Comprehensive Environmental Response Compensation and Liability Act \\ COG cell off-gas \\ CTD Chemical Technology Division \\ D\&D decontamination/decommissioning \\ DOE Department of Energy \\ Duratek Duratek Federal Systems \\ EAL emergency action level \\ EM Environmental Management \\ ES\&H environment, safety, and health \\ FEVA Facility Environmental Vulnerability Assessment \\ FFA Federal Facilities Agreement \\ FUA Facility Use Agreement \\ FWENC Foster Wheeler Environmental Company \\ FY fiscal year \\ HA hazard assessment \\ HEPA high-efficiency particulate air \\ HFBR High Flux Beam Reactor \\ HFIR High Flux Isotope Reactor \\ ISMS Integrated Safety Management System \\ LLLW liquid low-level waste \\ LOG laboratory off-gas \\ Mgd million gallons per day \\ Mgy million gallons per year \\ NESHAPs National Emission Standards for Hazardous Air Pollutants \\ NFMF Nuclear Facility Managers Forum \\ NPDES National Pollutant Discharge Elimination System \\ ORNL Oak Ridge National Laboratory \\ P2/WM Pollution Prevention and Waste Minimization Program \\ PBMS Performance Based Management System \\ PCB polychlorinated biphenyl \\ PNNL Pacific Northwest National Laboratory \\ PW process waste \\ RCRA Resource Conservation and Recovery Act \\ RDL Radiochemical Development Laboratory \\ RH remotely handled \\ RMAL Radioactive Materials Analytical Laboratory \\ ROI return on investment \\ S\&M surveillance and maintenance \\ SAA satellite accumulation area \\ SADS sink and drain survey \\ SBMS Standards Based Management System
}


SLLW

SPCC

SWSA

TRL

TRU

VOG

WAC

WOCC solid low-level waste

spill prevention, control, and countermeasures

solid waste storage area

Transuranium Research Laboratory

transuranic

vessel off-gas

waste acceptance criteria

Waste Operations Control Center 


\section{Executive Summary}

\section{Overview}

From mid-April through the end of June 2001, a Facility Environmental Vulnerability Assessment (FEVA) was performed at Oak Ridge National Laboratory (ORNL). The primary goal of this FEVA was to establish an environmental vulnerability baseline at ORNL that could be used to support the Laboratory planning process and place environmental vulnerabilities in perspective. The information developed during the FEVA was intended to provide the basis for management to initiate immediate, near-term, and long-term actions to respond to the identified vulnerabilities. It was expected that further evaluation of the vulnerabilities identified during the FEVA could be carried out to support a more quantitative characterization of the sources, evaluation of contaminant pathways, and definition of risks. The FEVA was modeled after the Battelle-supported response to the problems identified at the High Flux Beam Reactor at Brookhaven National Laboratory. This FEVA report satisfies Corrective Action 3A1 contained in the Corrective Action Plan in Response to Independent Review of the High Flux Isotope Reactor Tritium Leak at the Oak Ridge National Laboratory, submitted to the Department of Energy (DOE) ORNL Site Office Manager on April 16, 2001.

This assessment successfully achieved its primary goal as defined by Laboratory management. The assessment team was able to develop information about sources and pathway analyses although the following factors impacted the team's ability to provide additional quantitative information:

- the complexity and scope of the facilities, infrastructure, and programs;

- the significantly degraded physical condition of the facilities and infrastructure;

- the large number of known environmental vulnerabilities;

- the scope of legacy contamination issues [not currently addressed in the Environmental Management (EM) Program];

- the lack of facility process and environmental pathway analysis performed by the accountable line management or facility owner; and

- poor facility and infrastructure drawings.

The assessment team believes that the information, experience, and insight gained through FEVA will help in the planning and prioritization of ongoing efforts to resolve environmental vulnerabilities at UTBattelle-managed ORNL facilities.

\section{Immediate Issues}

The FEVA did not identify any major vulnerabilities associated with the UT-Battelle-managed facilities that warranted immediate "stop work" or "initiate immediate response" actions. The assessment team evaluated 11 Priority 1 facilities that contain significant hazardous material inventories and typically conduct hot cell or glove box type operations that use relatively small quantities (on the order of grams to kilograms) of materials. The team also evaluated 64 Priority 2 facilities with smaller inventories of hazardous materials. No situations were identified where significant release of contaminants to the environment was occurring or where an imminent threat of a release existed. The FEVA did determine that significant environmental impacts could be associated with off-normal conditions such as inadvertent sprinkler discharge, fire, high winds, or seismic events. These lower probability events are evaluated as part of facility safety authorization basis, and environmental vulnerabilities are typically mitigated by a combination of safety and defense-in-depth systems. 
Guidance will be issued to Laboratory management and staff to include the resources (funding and staff) in the FY 2002 budget, which is currently being prepared, to support the actions needed to prioritize, plan, and implement responses to the recommendations contained in this report.

\section{Scope of Vulnerabilities}

Most of the environmental vulnerabilities that FEVA identified were well known by facility managers and staff and in many cases had been long standing issues. Local actions had been taken over the years to partially mitigate many of these by temporarily containing the sources and instituting a surveillance program to detect potential leakage. The vulnerabilities span the UT-Battelle facilities that are identified as surplus, scheduled for disposition, or are strategic facilities. Vulnerable areas include both facilities and the supporting infrastructure, presenting a formidable task for management to integrate and prioritize the resolution of identified issues. Vulnerabilities were also identified with the significant amount of surface and below-grade legacy contamination that is present at the ORNL site.

The current environmental policy and planning process should be capable of evaluating and prioritizing the actions needed to resolve the vulnerabilities identified; however, the baseline information that identifies vulnerabilities and that drives the decision process is not available in a form that assists senior management in this process. For a number of reasons that are outlined in the report, the majority of the vulnerabilities were not elevated to the senior management, were not funded, or stopped being sent forward. The lack of clearly defined ownership for infrastructure, the lack of specific facility process and pathway analysis, the lack of an integrated multimedia environmental protection strategy and plan, and the past reactive minimal compliance policies contributed to this significant deficiency.

\section{Control and Detection of Significant Releases}

Progress has been made at ORNL in reducing the overall scope of environmental vulnerabilities, and current initiatives will reduce them further. Many of the most significant legacy sources have been contained or removed, and the DOE EM Program will continue to reduce the source term through a prioritized and risk-based methodology. Overall, ORNL is controlling and would be able to detect large acute, chronic, or intermittent releases of contaminants to the environment. The integrity of the sink and drain study and the environmental monitoring program results add confidence that significant releases are controlled and that new releases would be identified.

\section{Control and Detection of Chronic Small Releases}

While UT-Battelle is able, with a good degree of assurance, to validate that there are no acute, largevolume, or intermittent releases from its facilities, the same assurance cannot be provided with respect to chronic or infrequent low-volume, low-concentration releases. This situation is due to significant masking from a deteriorated infrastructure (e.g., potable water, storm water, process waste, sanitary sewer), the large amount of legacy contamination at the ORNL site, and volumetric dilution due to the use of large quantities of single-pass cooling water. Low-volume or low-concentration sources cannot be detected at present because of this masking. Reduction in the volume of single-pass cooling water discharged to drain systems will enhance the capability to detect smaller releases and locate smaller leaks between facility and manhole. This volume reduction effort, however, may have the undesirable side effect of increasing concentrations at the treatment facility acceptance points in the storm water, sanitary sewer, and process waste system outfalls, which could negatively impact the ability to meet the current National Pollutant Discharge Elimination System (NPDES) permit limits. 


\section{Recommendations}

As indicated in High Flux Isotope Reactor (HFIR) Corrective Action 3A1, the development and prioritization of long-term corrective actions for ORNL facilities will be accomplished through the deployment of the Standards Based Management System (SBMS) and by the new Facilities and Operations Model. The assessment team has developed the following recommendations for consideration during this process.

Near-Term Actions: 2 Years or Less to Implement

- Develop and communicate UT-Battelle environmental expectations and policy to staff and stakeholders - in process

- Complete excess chemical inventory reduction initiative - in process

- Complete legacy waste identification and clean out - in process

- Complete funded infrastructure upgrades-in process

- Support continued funding of and integration with DOE EM Program activities at ORNL - in process

- Evaluate and pilot elimination of contaminant discharges to process waste system

- Determine return on investment (ROI) benefit and regulatory impacts associated with minimizing single-pass cooling water

- Determine destination of discharges from vacuum system moisture traps

- Review vulnerabilities noted by retired employees and reconcile with current conditions

- Conduct facility process evaluations as part of the Facility Operations and Maintenance Management System - in process

- Develop the Environmental Management System with emphasis on pollution prevention and waste minimization to prioritize strategic investments to meet management expectations - in process

Long-Term Actions: 2-10 Years to Implement

- Support continued funding of and integration with DOE EM Program activities at ORNL

- Develop and implement Strategic Facilities Upgrade Plan (subsurface)

- Implement recently updated Pollution Prevention Program, which calls for an integrated multimedia environmental risk analysis process

- Complete facilities infrastructure upgrades (e.g., drinking water, sanitary sewer, storm sewer, off-gas, and vent systems)

- Minimize the use of potable water for single-pass cooling water

- Develop "zero discharge" operations except in key and limited areas, determined through an exclusion process

- Consolidate operations to the main ORNL site (vacate Y-12 National Security Complex) and transition facilities to the EM Program 



\subsection{Introduction}

\subsection{Purpose and Scope}

From mid-April through the end of June 2001, a Facility Environmental Vulnerability Assessment (FEVA) was performed at Oak Ridge National Laboratory (ORNL). FEVA is one of the key components of the UT-Battelle team's efforts to evaluate and proactively manage the environmental vulnerabilities associated with the facilities at ORNL. Because UT-Battelle did not perform a comprehensive "due diligence" review prior to contract transition to determine the environmental, safety, and health (ES\&H) condition of facilities and associated vulnerabilities, the Department of Energy (DOE) directed UTBattelle to rely on the "pre-existing conditions" clause in the management and operations contract. This assessment is a first step in defining a baseline for existing facilities and environmental conditions.

The purpose of this assessment was to

- evaluate active and inactive ORNL facilities and infrastructure currently managed by UTBattelle for environmental vulnerabilities;

- focus on identifying the ORNL facilities, infrastructure, and programs with greatest environmental risk potential;

- identify the contaminant sources (e.g., facilities, buildings, systems);

- characterize the contaminant sources (e.g., radionuclides, chemicals);

- evaluate contaminant release pathways and determine potential environmental, health, and safety risk;

- identify and complete necessary immediate actions to mitigate risks; and

- identify long-term actions.

The expected outcomes of this assessment were

- data and analysis that support decision making for either immediate actions or acceptance of known risks,

- a formal report that documents the process and outcomes,

- tangible action and response to lessons learned at the High Flux Beam Reactor (HFBR) at Brookhaven National Laboratory (BNL) and High Flux Isotope Reactor (HFIR) at ORNL, and

- $\quad$ support to the HFIR corrective action closure plan.

UT-Battelle management requested that this assessment answer the question, "Are any UT-Battelle facilities discharging significant amounts of contaminants to the environment?" Answering this question is part of the direct response by UT-Battelle management to the discovery of the HFIR tritium leak in the process waste drain system piping leaving the reactor building. The FEVA was modeled after the Battelle-supported response to the problems identified at the HFBR at BNL. The FEVA described in this report is part of the corrective action commitments by UT-Battelle management made in the Corrective Action Plan in Response to Independent Review of the High Flux Isotope Reactor Tritium Leak at the Oak Ridge National Laboratory, submitted to the DOE ORNL Site Manager on April 16, 2001. This report satisfies Corrective Action 3A1 that states that ORNL will "conduct an ORNL Environmental Vulnerability Assessment to identify and characterize potential sources, determine the risk, and develop and initiate required immediate actions. (Development and prioritization of long-term corrective actions for ORNL facilities will be accomplished through the implementation of Corrective Action 3A2)." 
As indicated in the HFIR Corrective Action Plan, FEVA did not specifically include the facilities at ORNL that are managed by Bechtel Jacobs Company LLC (BJC) for the DOE Environmental Management (EM) program, but did include UT-Battelle interfaces with systems associated with these facilities (e.g., Facilities and Operations, Operational Safety, Environmental Protection and Waste Systems).

\subsection{Evaluation Process and Methodology}

\subsubsection{The Team}

The FEVA was performed by a team of highly qualified ORNL management and technical staff including:

- Hans Vogel (Team Leader), Operational Safety Services

- Dirk Van Hoesen (Deputy Team Leader), Environmental Protection and Waste Services Division

- Terry Bonine, Environmental Protection and Waste Services Division

- Nancy Dailey, Environmental Protection and Waste Services Division

- Steve Hamley, Operational Safety Services Division

- Jerry Hunt, Operational Safety Services Division

- Carlo Melbihess, Facilities Revitalization Project

- Bill Miller, Metals and Ceramics Division

- Carol Scott, Operational Safety Services Division

- David Skipper, Environmental Protection and Waste Services Division

- Charlie Valentine, Environmental Protection and Waste Services Division

- Glenn Anderson, Environmental Protection and Waste Services Division

The team was assisted by Jerry Swanks (advisor), Tom Etheridge (engineering liaison), and numerous ORNL facility staff. BJC and contractor staff who participated included Dick Kettelle, Ken Cook, Merle Lauterbach, Rick Pierce, Chris Scott, Mark Peet, and Jeff Maddox.

Independent review of the team's efforts was provided by John Burr (Independent Oversight, Pacific Northwest National Laboratory) and Tom Naymik (Battelle Memorial Institute, Columbus, Ohio).

In addition, input on environmental vulnerabilities was obtained from retired ORNL staff familiar with Laboratory history and operations.

\subsubsection{Overall Approach}

Environmental vulnerabilities result from the potential or actual release to the environment of materials that do not naturally belong there. To determine whether there are environmental vulnerabilities, one must determine the materials available for release (inputs), the potential release pathways (outputs) into the environment, the potential barriers (physical and programmatic) that prevent these releases, and the impact of the release on humans or the environment. In the short time available for conducting this assessment and considering the overall complexity of the ORNL site and facilities and the surrounding environment, a comprehensive and in-depth analysis of all ORNL facilities, infrastructure, and programs that may impact the environment was not possible. The assessment team, therefore, used available information as much as possible and prioritized the facilities, infrastructure, and programs that could be appropriately reviewed in the time allotted. Because of these limitations, this assessment should be considered a first-order analysis that provides insight, priority, and a roadmap for future activities. 
The overall approach taken in the assessment was to evaluate the ORNL site from a process, pathway, and barrier perspective, as shown graphically in Fig. 1. This shows a mass balance of materials coming into the site, the primary pathways by which they may be discharged from the site, and the primary barriers that are used to prevent the unwanted release of these materials into the environment. Within the site boundary are the research and support facilities, the supporting infrastructure, and the programmatic activities that provide barriers to the inadvertent discharge of materials to the environment. Figure 1 shows sample pathways but is not intended to show all environmental pathways.

The following sections of the report describe the programmatic barriers, infrastructure, and facilities that were selected for evaluation during FEVA, the results of the evaluations, and the environmental vulnerabilities that were identified. This information was developed through a combination of interviews with staff, review of documents and other information sources, and walkdowns of selected facilities. The content and conclusions of this report have been provided to involved Laboratory staff and BJC staff for factual review and have been presented to Laboratory management.

\subsubsection{Programmatic Barrier Selection and Review}

The following ORNL programmatic barriers were selected for review as representing the significant administrative and control mechanisms that are used within ORNL to eliminate the source of a material, limit its discharge, or provide information about the nature of a discharge. Each of these programs was reviewed at a fairly high level to determine its overall status, completeness, and effectiveness. This review was an "expert analysis" and is therefore qualitative in its judgment. The first eight barriers, which were judged to be critical elements in controlling environmental vulnerabilities, are described in more detail in Sect. 2.0.

- Standards Based Management System (SBMS)

- Performance Based Management System (PBMS)

- Environmental Policy

- Environmental Planning

- Sink and Drain Program

- Chemical Management Program

- Pollution Prevention and Waste Minimization Program (P2/WM)

- Ground Water Protection Plan

- Stack and Vent Program

- Storm Water Pollution Prevention Program

- Spill Prevention, Control, and Countermeasures (SPCC) Plan

- Chlorine Control and Monitoring Program 


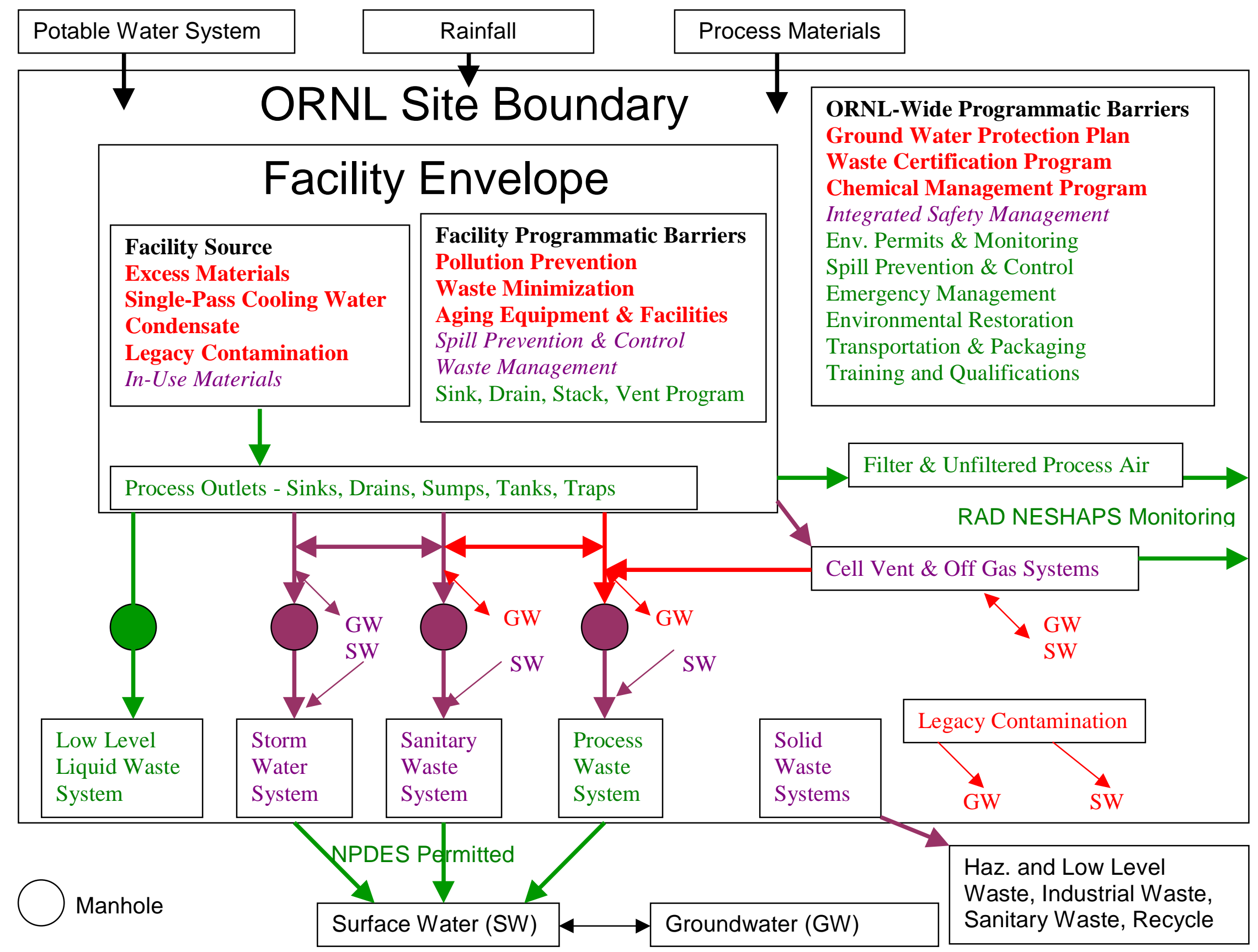

Fig. 1. Typical ORNL process/environmental pathways. 
- $\quad$ Emergency Preparedness

- Environmental Monitoring Plan

- Biological Monitoring Program

- Resource Conservation and Recovery Act (RCRA) permit

- Air permits

- National Pollutant Discharge Elimination System (NPDES) permits

- NPDES Storm Water Outfall Characterization Requirements Case

- National Emission Standards for Hazardous Air Pollutants (NESHAP) Monitoring and Reporting

- Environmental Management Program - Legacy Waste and Contamination

- Training and Qualifications Program

- Operational Awareness Assessments

- Integrated Safety Management System (ISMS)

\subsubsection{Infrastructure Selection and Review}

The following ORNL infrastructures were chosen by the team as representing the significant physical systems that provide barriers to the inadvertent discharge of materials or treatment and control for the various types of discharges to the environment. Each of these systems was reviewed to determine its function, current physical condition, and any vulnerabilities that exist are described in more detail in Sect. 2 .

- Potable Water System

- Steam Plant

- Process Waste (PW) System

- Liquid Low-Level waste (LLLW) System

- Storm Water System

- Sanitary Sewage Collection and Treatment System

- Gaseous Waste System (Cell Vent and Off-Gas System)

- Solid Waste Disposal System

- Vacuum System Moisture Traps

- Single-Pass Cooling Water

- Surface and subsurface

\subsubsection{Facility Selection and Review}

UT-Battelle manages 614 active and inactive ORNL facilities (based on the ORNL Facility Management Database as of April 16, 2001). A screening process was employed to select those facilities that present the greatest environmental risk potential. Selection criteria were the presence of large inventories of hazardous materials, high potential for release of contaminants to the environment, significant potential for environmental or safety impact, and routine generation of gaseous or liquid waste.

Through this screening process, 75 facilities were selected for near-term evaluation by the FEVA team. The remaining facilities will be evaluated in more detail during the development of Facility Use Agreements (FUAs) over the next year.

Facilities were identified as Priority 1 or Priority 2 facilities on the basis of their inventories and operations. The timeline for performing the assessment is shown in Fig. 2. 


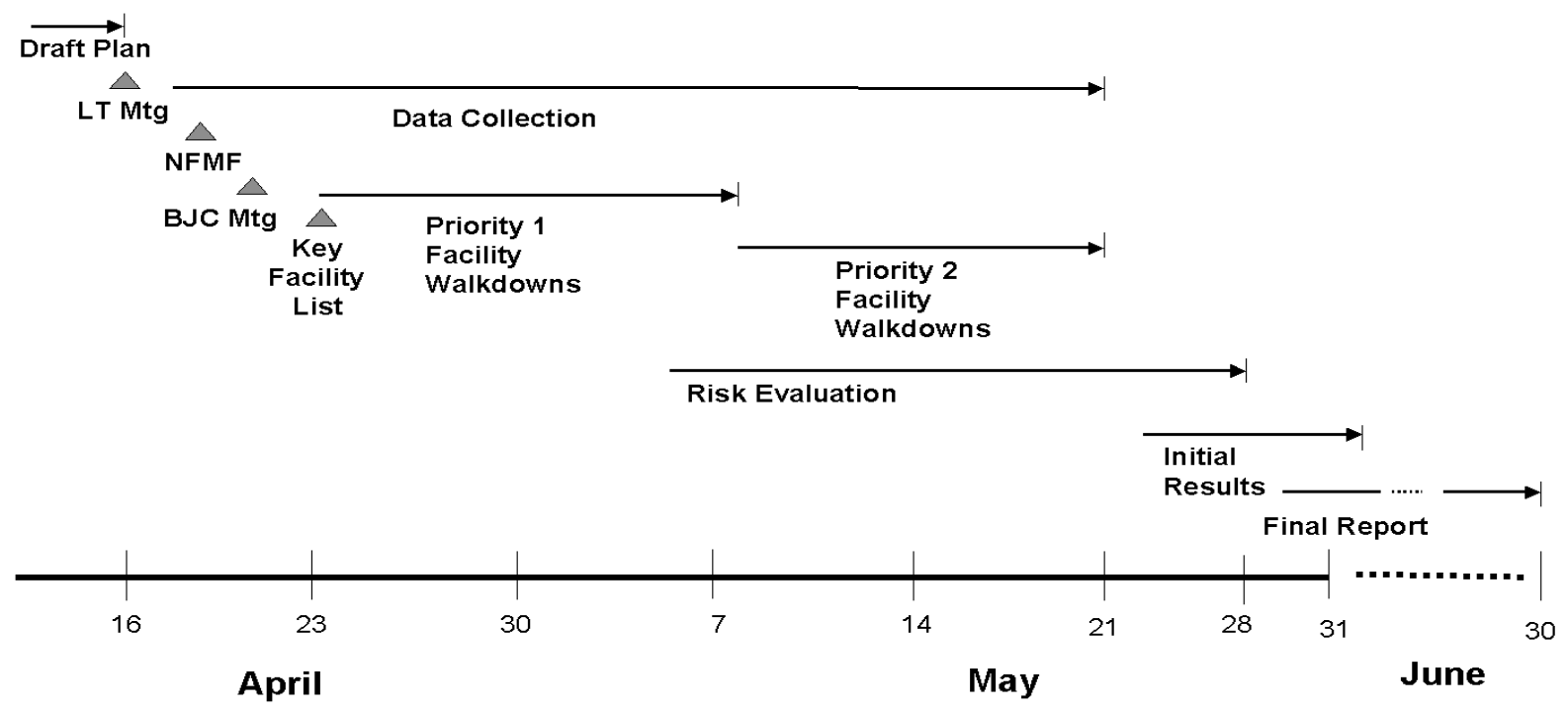

Fig. 2. Facility environmental vulnerability assessment timeline.

\subsubsection{Priority 1 Facilities}

Category 1, 2, or 3 Nuclear Facilities were identified as Priority 1 facilities (listed in Table 1). These facilities were expected to present the greatest potential for environmental vulnerability because of their significant radionuclide inventories and potential safety impacts as reflected by the facility categorization. One other facility, Building 4500S, was added to the Priority 1 list because of the broad range of activities conducted there, the number of research organizations present, and the large amount of liquid waste generated in the facility that is discharged to the PW system.

Table 1. Priority 1 facilities

\begin{tabular}{ccc}
\hline 2026 & 3047 & 5505 \\
3019 & 3525 & 7900 \\
$3025 E$ & $4500 S$ & 7920 \\
3027 & 4501 & 7930 \\
\hline
\end{tabular}

The FEVA team members walked down and evaluated 11 of these Priority 1 facilities. Results of these evaluations are presented in Sect. 2.2. The only Category 1 Nuclear Facility at ORNL, the HFIR, was not addressed by the FEVA team because the recent extensive reviews conducted at this facility in response to the tritium in a PW system line leak had identified existing vulnerabilities.

\subsubsection{Priority 2 Facilities}

Priority 2 facilities were judged to present a lower degree of environmental vulnerability than Priority 1 facilities based on their inventories and operations. The Priority 2 facilities are listed in Table 2 . 
They were selected using the following screening criteria:

- only UT-Battelle facilities were selected;

- facilities that have high contamination areas as reflected in the ORNL Radiation Work Permit system;

- facilities that have a hazard rating other than an "Industrial/Generally Acceptable;

- facilities that contain hazardous material inventories that require Hazards Assessments

- facilities that discharge to the Central Radioactive Gaseous Disposal Facility-Building 3039 [operated by Duratek Federal Systems (Duratek) under subcontract to BJC] as indicated in "Effluent Guidelines for Central Radioactive Gaseous Disposal Facility-Building 3039 at ORNL";

- facilities that discharge to the Duratek-operated LLLW system as indicated in the Annual LLLW Generation Summary available on the Duratek Federal Systems Liquid and Gaseous Waste Operations Group web site;

- facilities that house individuals who are identified as authorized to approve discharges to the LLLW or PW system as reflected in the "ORNL liquid generator list" provided by Duratek;

- facilities connected to the PW system as indicated on "Process Waste Bethel Valley Block Diagram, Q3d-12791-2001, Rev. 1"; "Process Waste Bethel Valley Area Block Flow Diagram - Sheet 1\&2, J3E20015-E002," and "Duratek Federal Process Waste Atlas Drawings"; and

- facilities identified in the "UT-Battelle Sink and Drain Survey Database" as connecting to the PW system.

Reviews of Priority 2 facilities focused on specific aspects of each facility identified in the screening process (e.g., connected to the PW system).

Table 2. Priority 2 facilities

\begin{tabular}{cccc}
\hline 1059 & 3012 & 3150 & 5500 \\
1503 & 3017 & 3502 & $5510 \mathrm{~A}$ \\
1504 & $3025 \mathrm{M}$ & 3503 & $5510 \mathrm{P}$ \\
1505 & 3034 & 3504 & 6000 \\
1506 & 3036 & 3508 & 6005 \\
2000 & 3037 & 3534 & 6010 \\
2001 & 3044 & 3541 & 7040 \\
2024 & $3047 \mathrm{~A}$ & $3544 \mathrm{~A}$ & 7902 \\
2500 & 3074 & 3550 & 7903 \\
2519 & 3080 & 3587 & $7911 \mathrm{~A}$ \\
$2519 \mathrm{~A}$ & 3091 & 3592 & 7913 \\
2523 & 3108 & 3597 & 7917 \\
2528 & 3114 & $4500 \mathrm{~N}$ & 7932 \\
2547 & 3121 & 4505 & 7957 \\
2643 & 3137 & 4508 & $7964 \mathrm{G}$ \\
3003 & 3144 & 4515 & $9204-3$ \\
\hline
\end{tabular}

Figures 3 and 4 show the locations of the Priority 1 and 2 facilities, the remainder of the UT-Battellemanaged ORNL facilities, the BJC-managed operating waste management facilities, and the BJCmanaged remediation facilities and areas. 


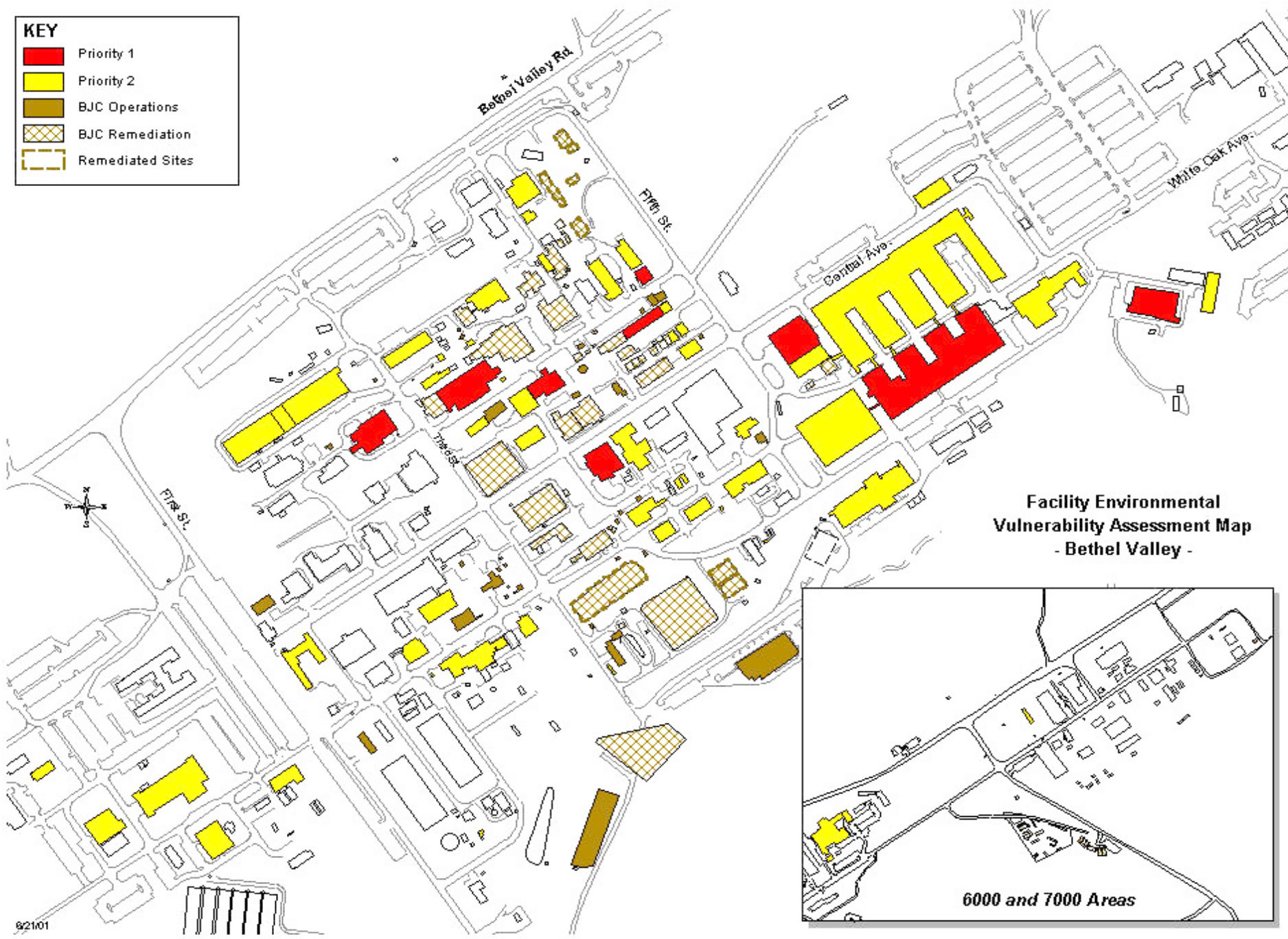

Fig. 3. Bethel Valley Facilities. 


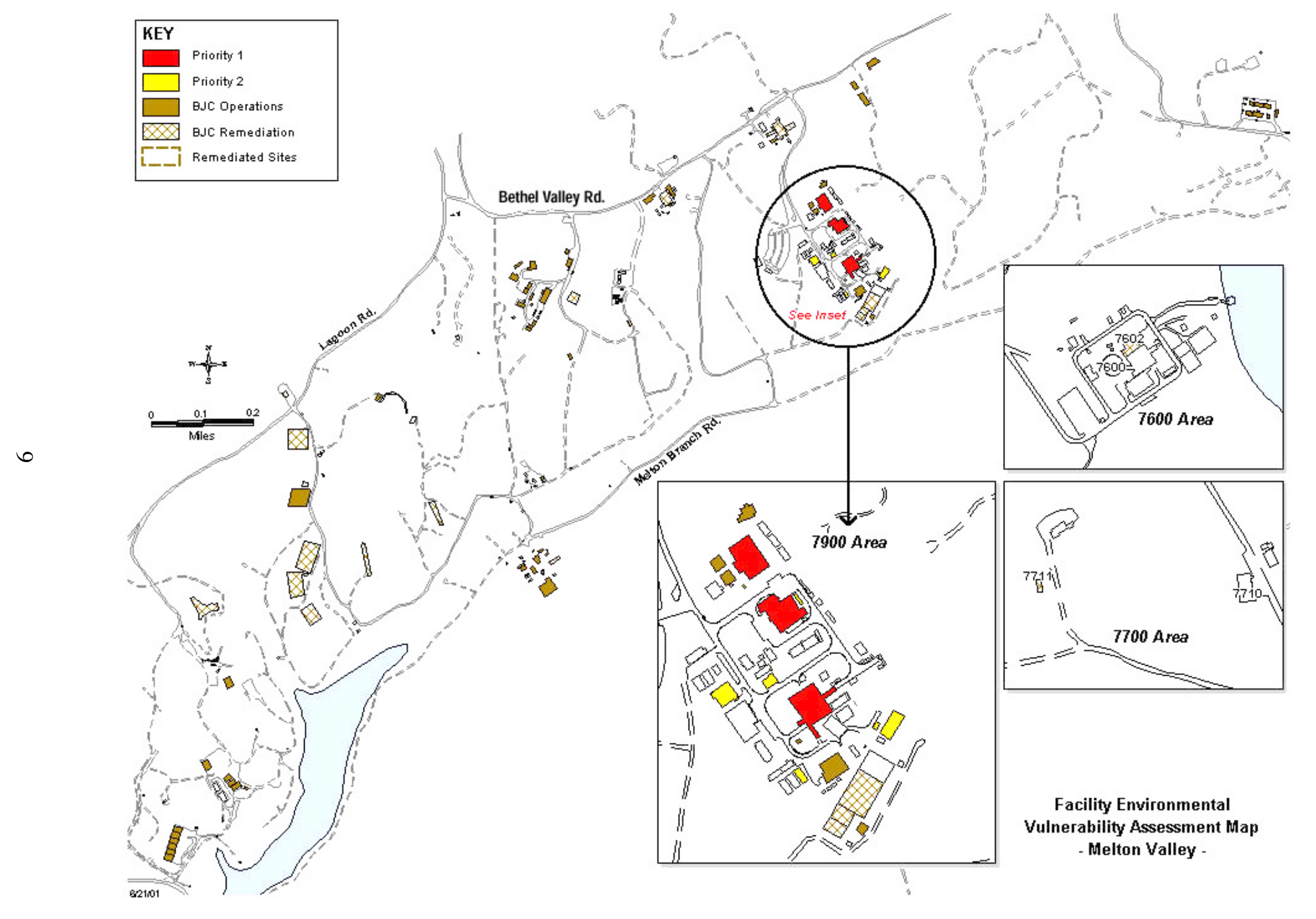

Fig. 4. Melton Valley Facilities. 


\subsubsection{Facility Walkdown Protocol}

To ensure consistency in the facility walkdowns, a standard protocol was established. The protocol included a review of the radiological and chemical material inventory, the administrative and engineered controls that are in place for containment and safe storage of materials, and potential release pathways that might exist for a source outside the bounds of the administrative and engineered controls. Specific assessments to be completed during the review included the risk from the material, the effectiveness of the controls preventing release, and the potential for unmonitored release of material to the environment or exposure of staff. Documented legacy conditions were also reviewed. The level of review of the facilities was graded to reflect the facility inventories, hazard potential, and risk. Priority 1 facilities were subjected to a thorough review process, while reviews of Priority 2 facilities focused on specific aspects of each facility as discussed in Sect. 1.2.5.2.

In an effort to expedite the assessment process, staff at BNL and Pacific Northwest National Laboratory (PNNL) were contacted in an attempt to capture previous assessment criteria used at these sites. The assessment checklist from PNNL appeared to cover all areas of concern for the ORNL assessment and was selected for use in this assessment (Exhibit 1). To ensure that an objective, thorough, and consistent review was conducted on the various sites and facilities, the team members reviewed the checklist. Each area of the PNNL checklist contained specific questions that were not directly applicable to facilities at ORNL. These differences were resolved and ORNL systems comparable to the PNNL systems addressed by the checklist were identified.

During the review process, if vulnerabilities were mitigated by administrative controls, a spot check of the effectiveness of the administrative controls was done to verify the adequacy of the control for each facility. The intent was to document enough information to allow the performance of an evaluation of hazards and to identify legacy hazards that exist in UT-Battelle facilities. 


\subsection{Observations}

\subsection{Programmatic Barrier Review}

The eight programmatic barriers discussed in Sects. 2.1.1-2.2.8 were reviewed to determine their overall status, completeness, and effectiveness.

\subsubsection{Standards Based Management System}

The SBMS is the new tool at ORNL for setting common institutional standards (performance expectations) and conveying these requirements to staff. This requirements management tool developed and deployed at the PNNL, was successfully deployed at BNL, and now is being deployed at ORNL. It has a proven track record of accomplishment and when fully deployed at ORNL will provide the necessary framework for delivering a common set of requirements to managers and staff. The concept is simple - staff need only adhere to the requirements in the SBMS to know that they are in compliance with all of the myriad federal, state, local, DOE, and UT-Battelle requirements.

The SBMS deployment at ORNL is in its early stages - most new management systems descriptions and laboratory-level policies have been written, a number of program descriptions have been created directly from existing guidance, a small number of subject areas have been created, and a strategy for creating and populating the FUAs has been developed. A detailed project management plan has been developed to guide the full deployment of the SBMS. This is currently planned to be a multiyear process that will require operating under two different systems for an extended period of time. The FEVA will be used to support implementation of SBMS.

\subsubsection{Performance Based Management System}

The PBMS is the new tool at ORNL for setting a common framework and methodology for measuring organizational and management systems performance against the Laboratory Strategic Plan and Critical Outcomes. It is the method to be used across the Laboratory to determine whether the Laboratory is meeting its goals and objectives in the areas of science, operations, ES\&H, community relations, etc. The basic functional elements of the system include organizational self-assessments, independent oversight, independent audit, and scientific peer review. This performance measurement tool was developed and deployed at PNNL, was successfully deployed at BNL, and now is being deployed at ORNL. The concept is simple - managers self-assess their work against the requirements in the SBMS and the annual business plan, report these results, and take appropriate actions when results do not meet expectations. Independent oversight, internal audit, and peer review provide an independent assessment of laboratory, organizational, and management systems performance to provide further confidence that managers and staff are meeting senior management's expectations. The PBMS is an integral part of the Laboratory Integrated Planning Process.

The PBMS has been developed and initial deployment has begun. Each organization has developed its first annual self-assessment plans for FY 2001, and the Office of Independent Oversight is scheduled to perform the first independent review of these self-assessment programs soon. A rigorously deployed PBMS that fully discloses where performance does not meet expectations and drives actions to improve performance is absolutely essential to the Laboratory's future success.

\subsubsection{Environmental Policy}

The officially published Environmental Policies of ORNL are clearly articulated in the ORNL SBMS and are shown below in extracted form. These policies are appropriate, and when fully embraced and 
implemented at all working levels within the Laboratory, they will result in a more proactive environmental culture.

ORNL Policy [Issue date: April 27, 2001] includes the following environment-related statements:

- All staff shall comply with all applicable laws, regulations, contractual obligations, and with UTBattelle policy.

- ORNL is committed to adhering to applicable federal, state, and local ES\&H laws, regulations, and requirements, as defined by the required compliance documents.

- ORNL is committed to providing a safe and healthy working environment for all staff, guest scientists and engineers, and visitors; protecting the general public and the environment from unacceptable ES\&H risks; and operating in a manner that protects and restores the environment.

- ORNL is committed to objectively and fully communicating environmental protection, safety and health information to ORNL staff, subcontractor personnel, DOE, applicable stakeholders, and the public.

Management System Description: Environmental Management [Issue date: March 26, 2001] states: It is UT-Battelle's policy to integrate environmental management into all facets of the Laboratory's missions. UT-Battelle will manage its programs in a manner that protects human health and the environment. ORNL is committed to adhering to applicable federal, state, and local environmental laws, regulations, and requirements. In support of this policy, UT-Battelle makes the following commitments:

- UT-Battelle will communicate to employees, contractors, guests, and visitors their environmental management responsibilities and UT-Battelle environmental management goals.

- In consideration of the potential impacts of ORNL activities on the environment, UT-Battelle will integrate $\mathrm{P} 2 / \mathrm{WM}$, resource conservation, and compliance into all of its planning and decision making.

- UT-Battelle will work with regulatory agencies and customers on proactive initiatives to improve the cost-effectiveness of environmental management performance.

- UT-Battelle will conduct periodic assessments of environmental management performance and share and utilize lessons learned in support of continuous improvement.

- UT-Battelle will define, prioritize, and aggressively correct environmental issues associated with its operations.

- UT-Battelle will work to continually improve its environmental management system and performance. UT-Battelle will establish appropriate environmental and waste management objectives and performance indicators to guide these efforts and measure its progress.

- UT-Battelle will maintain a positive, proactive, and constructive relationship with its neighbors in the community, regulators, DOE, and other stakeholders. UT-Battelle will openly communicate with stakeholders on its progress and performance.

At the time of this review, interviews and evidence gathered indicate that these policies, with the exception of those focused on "compliance," have yet to be ingrained or active in the culture of the Laboratory. Rather, there remains the traditional culture of "minimal compliance" that is reactive only to regulatory oversight pressure, lawsuits, or contract conditions. This culture was fostered by efforts such as "Necessary and Sufficient Standards" and "Work Smart Standards" that eliminated "best management practices" not strictly required by rule or regulation. Staff repeated again and again in interviews that while they have heard that the new management team takes a different approach to environmental management, they have yet to see a clear physical and monetary commitment to reversing the "minimal compliance model." The environmental policies noted above were only recently published, and have not had sufficient time to have an impact on the existing culture. There is clearly a need to demonstrate 
management commitment to the new environmental policies and associated line management accountability through actions such as following through with responses to this assessment.

\subsubsection{Environmental Planning}

The integrated planning process used at ORNL has undergone significant change over the past two planning cycles and will continue to be refined over the next several years as the Laboratory migrates toward the new UT-Battelle management systems and customer support models as articulated in the SBMS. The current planning process provides an appropriate methodology for incorporating environmental management issues. The Institutional Plan, Laboratory Strategic Plan, Laboratory Agenda, Performance Evaluation Plan, Strategic Facilities Plan, Life Cycle Asset Management Program, Land and Facilities Plan, and Integrated Environment, Safety, Health, Quality, and Infrastructure Management Plan have recognized the importance of environmental stewardship and contain a prioritization process for determining which issues require the most attention by management.

The overall integrity and comprehensiveness of the current planning process depends primarily on the individual divisions to perform comprehensive planning and identification of all requirements and operational demands. The process is only as good as the basic input data that drives it. Unfortunately, evidence gathered during this assessment indicates that in the past, senior management did not have the environmental vulnerability data that it needed to make appropriate judgments and set priorities to achieve the goal of long-term operational sustainability of the Laboratory. This assessment identified a number of environmental vulnerabilities that were well known by the divisions for many years, but these issues had not consistently been elevated through the planning process to senior management. There are a number of reasons for this, including the following:

- The previous culture of "reactive compliance-driven environmental management" appears to have resulted in historical underfunding of facility and infrastructure maintenance and upgrades that sent a clear message to Laboratory managers not to send forward for funding environmental vulnerabilities that did not have a "compliance driver."

- Prior organizational constructs and focus have contributed to this lack of identification of issues. "Stovepiped" funding sources and lack of landlord participation led to a narrow focus on facilities and infrastructure management. The prior management model provided all divisions with a set of high-level laboratory policies, directives, and guidance and left it up to individual divisions to implement these as they saw fit. Recent external reviews and this assessment have found evidence that the level of implementation of these requirements has been quite variable. While some organizations have attempted to implement these requirements in a disciplined way, others have chosen to manage to different priorities. The new UT-Battelle management is making significant strides in moving away from this narrow organizational management model. The development and deployment of the SBMS, which provides for consistent laboratory-level requirements and the PBMS, which provides the mechanism for the organizations to evaluate their implementation of the SBMS, address this issue. The Strategic Facilities Plan and the recently completed hot-cell study also clearly indicate that a more global approach is being taken.

- Past "compliance-oriented" practices have led to the development of programs and processes that are not fully integrated. The myriad of "programs, processes, and requirements" that research organizations must comply with as responsible "facility operators" is overwhelming to most research organizations. Many federal, state, local, DOE, UT-Battelle, and stakeholder 
programs and requirements are overlapping and interrelated; only a fully integrated site-wide, multimedia environmental management approach at a Laboratory-level with the expertise and budget to address these programs can be effective and efficient.

- Comprehensive facility process evaluations and environmental pathway analysis, required by the Pollution Prevention and Waste Minimization Program and the Integrated Safety Management Program, have not been conducted for each facility or process. The intent of such evaluations is to identify the work conducted, the materials used in the process, the wastes and by-products produced, the pathways through which these products might enter the environment, and the controls necessary to mitigate the release. Without these evaluations, there is little baseline data from which to plan or to judge the effectiveness of initiatives. No process exists to provide this level of information, nor has funding been identified to develop such a process. It is expected that the Environmental Management System and the Facility Operations and Maintenance Management System will work together to perform these analyses.

During this assessment, the assessment team reviewed a large number of individual environmental planning- and permit-related documents that are primarily required by regulatory agencies or DOE. The documents reviewed include

- Ground Water Protection Plan

- Storm Water Pollution Prevention Plan

- SPCC Plan

- Environmental Monitoring Plan

- Biological Monitoring and Abatement Plan

- Pollution Prevention and Waste Minimization Plan

- RCRA permit

- NPDES permit

- Air Permit

- Radiological NESHAP Monitoring Plan

- Strategic Facilities Plan

- Land and Facilities Plan

These documents are well written and appropriately address the individual planning and regulatory requirements. Each of these is a stand-alone document that satisfies regulatory drivers, but operates in a mostly independent mode. There are some cross-references within these documents to other documents, but there is generally little integration among them. Each individual programmatic owner (e.g., subject matter expert) was responsible for the program's particular product. Some of these documents are internally available on the ORNL Intranet; however, no central repository exists nor is any one person responsible for integrating and coordinating them.

No single document describing a comprehensive environmental protection strategy provides a clear picture of environmental planning that could be used by senior management in an integrated planning process for the Laboratory. The current Work Smart Standards do not include the requirement to write an Environmental Protection Plan as outlined in DOE Order 5400.1 and ORO Order 420.1.

\subsubsection{Sink and Drain Program}

Pursuant to Federal Court Order No. 3:92-cv-0036 (Order) issued September 26, 1996, DOE was required to complete a comprehensive survey of all pipes, sinks, and other connections to ORNL storm drain systems within one year of the issuance of the Order (i.e., by September 26, 1997). The Order further 
stipulated that during the course of the survey or at any time thereafter, sources found to be inappropriately connected to a storm drain system must be immediately placed under administrative control and the sources plugged, disconnected, or rerouted within 10 days of their identification as inappropriately connected sources. In addition, since this was a permanent court order, ORNL must routinely verify and update, as necessary, the drain information verified for the September 26, 1997, report deadline.

The sink and drain program was evaluated in some detail because of the overall potential impact of this pathway on the environment. The protocol used to conduct the sink and drain survey (SADS) was found to be well written and comprehensive, including information on all drain connections at ORNL, not just storm drain connections. Clear and direct guidance was provided to all facility management on the expectations for the conduct of the study, labeling, and recording in the database. A number of controls were put in place to ensure the timeliness and quality of the study and the rerouting of drains as needed. Each organization conducted its own study using the guidance provided. Staff currently in the Water Quality Program of the Environmental Protection and Waste Services Division provided oversight and guidance during the process and physically visited a large number of facilities to assist with and view the conduct of the study.

Because of funding limitations, there was no formal, independent oversight of the initial study to validate that each organization had adhered fully to the guidance provided; however, some oversight data available through the Operational Awareness Program, provides some confidence that the sink and drain study was reasonably comprehensive. Operational walkdowns of most facilities have been accomplished under the Operational Awareness Program over the past three years. One of the key areas monitored by the environmental subject matter expert team member is the integrity of the SADS and identification of other environmental vulnerabilities. While the individual results of the walkdowns are "no fault" and left for the facility management to act on, the Operational Awareness Program manager periodically collates and analyzes the results of the walkdowns for trends and issues of interest to management. Results for the past three years show the following:

- Potential discharge to waterways (210 findings)

○ Lack of secondary containment for instruments/machinery

- Actual oil spill and leaks from instruments and machinery

- Storage of hazardous materials near drains in which leaks and/or spills have reached the drain system

- Signs/labeling (169 findings)

$\circ \quad$ Unidentified floor or sink drain $(<5 \%)$

$\circ$ Drain missing or illegible labels $(45 \%)$

○ Wrong or inappropriate labels $(50 \%)$

The results of these surveys, combined with the checking of the sinks and drains conducted during the FEVA show that there is reasonable confidence that almost all drains have been evaluated, labeled, and determined to be appropriately connected to the intended system. In addition, it is clear that considerable room for improvement remains in the area of potential discharges to the storm water system due to inappropriate storage of materials near storm drains. This issue has been brought to the attention of all managers through memos from senior management and through the lessons learned program; however, this issue continues to be one of the most frequently found environmental vulnerabilities during the operational walkdowns.

\subsubsection{Chemical Management Program}

The Chemical Management Program was not reviewed in detail as part of the FEVA except to review the components of the program and its integration with the environmental programs. Chemical management 
under ISMS has been given considerable attention over the past year following the discovery of large quantities of excess chemicals in the workplace, large quantities of legacy wastes in some workplaces, inaccuracies in the hazardous materials inventory system, and inappropriately stored chemicals. The FEVA facility walkdowns validated that these issues continue to exist, but several key chemical management initiatives (e.g., Chemical Management Center, Excess Chemical Inventory Reduction Initiative, Legacy Waste Identification and Clean Out Initiative) now under way are mitigating these issues.

\subsubsection{Pollution Prevention and Waste Minimization Program}

The Pollution Prevention and Waste Minimization (P2/WM) Program is described in a P2/WM Plan in the SBMS, and additional guidance is available on the ORNL Intranet. The overall program as described in these documents appears appropriate as Laboratory-level guidance. There is evidence that a number of excellent initiatives have taken place at the Laboratory level in the areas of recycling and pollution prevention opportunity assessments. The use of specific materials has been reduced or eliminated. These initiatives, while good, do not demonstrate a robust program that has depth or breadth. In addition, little evidence exists to indicate that the divisions embraced P2/WM concepts. Furthermore, few divisions have conducted process evaluations and pathway analysis as called for by the P2/WM requirements, which contributes to many of the vulnerabilities noted in this assessment.

\subsubsection{Groundwater Protection Program}

A UT-Battelle Groundwater Protection Program Plan exists but is currently under review and may require revision to reflect the results of the Independent Review of the High Flux Isotope Reactor Tritium Leak at the Oak Ridge National Laboratory. The adequacy of the current groundwater monitoring around UTBattelle operating facilities will be a part of this overall review. Many existing wells could be used to provide an enhanced level of surveillance of the groundwater. Until two years ago, many of these wells were sampled on a routine basis through the EM Program. At that time, DOE EM decided to discontinue funding much of its well-monitoring activities.

\subsection{Infrastructure Review}

\subsubsection{Overview}

ORNL's main site encompasses approximately 1100 acres in the Bethel and Melton Valleys, approximately 10 miles southwest of the center of the city of Oak Ridge, Tennessee, with additional facilities located on the adjacent Copper Ridge. ORNL also occupies space at the Y-12 National Security Complex and leases some space off-site. Buildings at the Melton Valley and Bethel Valley sites and Copper Ridge comprise approximately 3 million gross square feet of building space; at the Y-12 National Security Complex, ORNL use accounts for approximately 1.4 million gross square feet of building space.

UT-Battelle has full responsibility for its Bethel Valley and Melton Valley sites and surrounding areas with the exception of facilities managed by DOE prime contractors, BJC and Foster Wheeler Environmental Company (FWENC), under the DOE EM program. As the site "landlord," UT-Battelle operates and maintains utility systems and common areas; provides emergency response, fire, and security services; and performs site environmental monitoring. UT-Battelle waste generators must characterize, package, and certify solid waste to meet a set of master waste stream profiles developed by BJC. UT-Battelle liquid and gaseous waste generators must meet a set of waste acceptance criteria (WAC) for the BJC operated treatment facilities. 
BJC is responsible for operating the liquid and gaseous waste systems, storing/disposing of solid waste, remediating contaminated soils and groundwater, and decontaminating/decommissioning certain inactive facilities. Remediation activities in Melton Valley are being conducted under an approved Comprehensive Environmental Response, Compensation, and Liability Act (CERCLA) Record of Decision (ROD), and a ROD for Bethel Valley is currently in the final approval stages. FWENC is responsible for construction and operation of the Transuranic Waste Treatment Facility located in Melton Valley. An MOU with BJC identifies roles and responsibilities for the organizations. At the completion of these EM missions, these areas and responsibilities are expected to transition back to the site landlord.

At the Y-12 National Security Complex, ORNL has responsibility for building maintenance and ESH\&Q functions for all ORNL facilities as approved by the MOU between ORNL and BWXT. UT-Battelle is also responsible for management of a 21,076-acre portion of the approximately 34,424-acre Oak Ridge Reservation, including ORNL facilities and most of the 20,000-acre Oak Ridge National Environmental Research Park.

The majority of current ORNL space is substandard and needs to be replaced or upgraded in order to support the long-term research mission of the Laboratory. ORNL has one of the oldest physical plants in the DOE laboratory system, and continuing efforts will be required to renovate and rehabilitate general-purpose buildings and utility systems that have deteriorated, as well as to provide for new mission-related facilities for expanded scientific endeavors. The systems having the greatest need for refurbishment or replacement are those related to the upgrade of electrical distribution systems, process/chilled water systems, ventilation and exhaust systems, transportation infrastructure, and security. Many of these upgrades are driven by health and safety requirements that can no longer be met by 35- to 50 -year-old electrical or heating, ventilating, and air-conditioning equipment, or for which reliability concerns cannot be tolerated (e.g., the primary potable water systems).

ORNL faces an enormous challenge in the deactivation and disposition of its nonstrategic facilities. Many of these facilities are large and complex, and some contain multiple hazards. As ORNL facilities reach their end of expected life and are declared excess, they transfer from an operational mode into a transition phase that prepares them for ultimate disposition. The transition phase of a facility's life cycle typically includes deactivation, surveillance and maintenance (S\&M), and decontamination/decommissioning (D\&D).

The Facility Revitalization Project strategy is to consolidate Laboratory research and support operations into a set of strategic facilities located at the main ORNL site. This plan results in the reduction of ORNL space from the current level of over 4.4 million square feet to slightly over 3.2 million square feet. This consolidation effort would occur over a 5- to 7-year period, involving the movement of slightly over 400 staff from off-site locations (e.g., Y-12 Complex, 1060 Commerce Park, and 111 Union Valley Rd.) to renovated existing space and 600,000 gross square feet of new facility construction. This new space would be at the main ORNL site or be provided through new private-sector buildings, state-funded buildings, and DOE line item funding. New space could also be made available through general plant and equipment projects, which would result in the need for the deactivation and demolition of approximately 118 buildings and trailers that account for approximately 1.8 million gross square feet of space.

A significant challenge facing senior management is the effective integration and coordination of the DOE Science-funded Facility Revitalization Project, the DOE EM-funded Environmental Restoration Program, and the DOE Facility Transition Program. Each of these programs has its own unique set of environmental vulnerabilities that must be considered. Each program has its own prioritization systems 
that may not be in sync with the others, and each program has different funding sources. A more holistic approach in the identification and prioritization of the interrelated environmental vulnerabilities will be necessary to ensure effective coordination of these programs and therefore more efficient utilization of resources.

\subsubsection{Potable Water Supply}

Potable water is used for domestic, sanitary, fire protection, and process purposes. Water usage is approximately 2.5 million gallons per day (Mgd) on a winter day and $4 \mathrm{Mgd}$ during the summer, although on a very hot day, water usage can approach $5 \mathrm{Mgd}$. A flow of $7 \mathrm{Mgd}$ can be accommodated by the ORNL supply system under current operating conditions. On average the daily potable water usage at ORNL is just over $3 \mathrm{Mgd}$ or almost 1.1 billion gallons per year. Considering its age, the general condition of the water system is good, but some areas need improvement.

The current system is known to leak out water, especially in the older process areas within the plant, but the leakage volume has not been formally quantified. The ORNL utilities department has an ongoing effort to find and fix these potable water system leaks. However, this leakage could move radioactive material and other contaminants into groundwater and surface water by finding various pathways, including the storm drains, sewer, and process waste. In August 2000, an assessment was performed that affirms ORNL's potable water is safe to use and consume. Additionally, the assessment demonstrated that ORNL has long recognized the importance of providing potable water to the site. In the early phases of Laboratory development, separate potable water and process water systems were used. However, as ORNL expanded, it became apparent that continuing the use of two separate water systems was not feasible. At that time, ORNL took great pains to prove that the use of reduced-pressure principal backflow preventers was indeed a means of physically separating potable water systems from process water systems. This practice continues to be an effective means of ensuring quality potable water at the Lab.

The assessment also determined that the Laboratory is meeting State requirements for its current water distribution sampling plan and that this plan remains a viable means for the Laboratory to assure it is providing quality potable water to the Laboratory. Results of the analysis for radiological contamination of the potable water system confirm steps to prevent contamination of potable water supplies continue to be effective.

\subsubsection{Steam Plant}

The steam plant has been a major contributor to environmental releases because of the material burned (coal, gas, or oil), wastes generated by the support equipment such as, water-softener systems, the fuel oil pumping system, and the coal-handling system. The recent decision to convert the steam plant to natural gas with a fuel oil backup will reduce the environmental vulnerabilities associated with the current plant. Now that the steam plant has a total natural gas/fuel oil capability, the coal contracts have been terminated and coal inventories have been burned off. After the coal is removed from the coal yard, steps will be taken to stabilize that area and return it to its original "green" state. When coal is no longer burned, precipitators used to remove coal particulates from the flue gas and the ash conveying and disposal system will no longer be needed and should be disconnected and removed. Coal-handling equipment in the steam plant itself will need to be removed to prevent future problems. The Coal Yard Runoff Treatment Plant, designed to process highly acidic wastewater from the coal yard, will no longer be needed after the coal yard has been shut down. The greatest benefit will likely be the greatly diminished potential for environmental incidents and the reduction in the amount of materials released to the environment.

Approximately $40 \%$ of the steam condensate is recycled back to the steam plant for reuse. The remainder of the condensate evaporates or is discharged to the storm water, sanitary sewer, or PW system, or 
directly to the ground. Process knowledge indicates that no contaminants of concern are contained in the condensate.

\subsubsection{Process Waste System}

The process waste (PW) collection system is operated by a BJC subcontractor, Duratek, and consists of a series of underground pipes where process waste water flows from the source facility to a pumping station for transfer to the Process Waste Treatment Complex-either Building 3544 (for radiological treatment) or Building 3608 (for nonradiological treatment). The WAC administratively limits the wastes that can be added to the PW system to a total radionuclide concentration of the ingestion dose equivalent of $1 \times 10^{4}$ $\mathrm{Bq} / \mathrm{L}{ }^{90} \mathrm{Sr}$. Chemicals are limited based on treatment system capabilities and effluent discharge permit limits. At strategic points throughout the collection system, manholes are equipped with beta-gamma radiation monitors, $\mathrm{pH}$ monitors, and flow monitors that are continuously monitored at the Waste Operations Control Center (WOCC) to allow personnel to detect any unusual activity within the system.

The overall PW system has undergone a number of upgrades over the past 10 years that have significantly improved its integrity and process dependability; however, the integrity of the PW system piping from UT-Battelle facilities to connecting manholes remains a vulnerability. Most of the PW system was constructed with vitreous clay tile pipe. Upgrades to the system were performed several years ago to line the main trunk lines between the major manholes and the treatment plants using the "insituform" process. There have been few upgrades to the piping between the facilities and the first PW system manholes.

Leaks have been detected in this type of pipe over the years, and it is likely that some of the remaining clay pipe is leaking. Leakage could be infiltration or exfiltration depending on the other hydraulic gradients in the area. BJC estimates that there are approximately 60 million gallons per year (Mgy) of water collected from EM Program sources such as building sumps, tank inleakages, contaminated groundwater collection, etc. In addition to this, over $100 \mathrm{Mgy}$ of single-pass cooling water is discharged to the PW system (see Sect.2.2.11). It cannot be determined from current data if there is leakage, and if so, how much leakage is occurring from the connections to the PW system.

An additional potential environmental vulnerability arises from the inability of each facility or operation to quantitatively demonstrate that its discharges to the PW system are meeting the required BJC WAC for the system. Most facilities do not have the capability to quantitatively measure the flow and concentration of their discharges to the PW system. No requirement exists for generators to record their discharges to the PW system, and WAC compliance relies primarily on administrative controls. Generator training is the primary method currently used to ensure that WAC are met.

\subsubsection{Low-Level Liquid Waste System}

The LLLW system is operated by a BJC subcontractor, Duratek, and collects, neutralizes, concentrates, and stores aqueous radioactive waste solutions from various sources at the Laboratory. The WAC administratively limits the wastes that can be added to the LLLW system to a total radionuclide concentration of the ingestion dose equivalent of $2 \times 10^{10} \mathrm{~Bq} / \mathrm{L}{ }^{90} \mathrm{Sr}$. Chemicals are limited based on treatment system capabilities and effluent discharge permit limits. The sources of these waste solutions are "hot" sinks and drains in research and development laboratories, radiochemical pilot plants, and nuclear reactors located in both Bethel and Melton Valleys.

The Federal Facilities Agreement (FFA) of 1992 resulted in a major upgrade to the LLLW system that provided for secondary containment for all double-lined pipes and tanks. In addition, the annulus between the primary pipe and the secondary pipe is pressurized, and the pressure is monitored at the WOCC. An alarm alerts the operators if the pressure drops below a set value. The upgrades to the system as a result of the FFA have been effective in controlling loss of LLLW to the environment. Environmental issues 
associated with legacy wastes generated as a result of operating the old system or resulting from the disconnections during the upgrade are being addressed by the DOE EM Program, but this area was not investigated during this assessment.

\subsubsection{Storm Water System}

The storm water collection system consists of drainage ditches, catch basins, manholes, and collection pipes that convey storm water, condensate, and cooling water flows to the receiving streams. White Oak Creek traverses the site and ultimately receives all the discharges from ORNL as well as normal flows from the four named tributaries that feed it. Rainfall, snow melt, and authorized discharges are directed to the gravity-drainage system that conveys the water from buildings, parking lots, streets, and roofs to specific outfalls. The collection system itself was installed in an unplanned manner over the years as ORNL developed and matured. The collection system has resulted in the existence of 146 NPDESpermitted storm water outfalls discharging into the receiving streams. To comply with ORNL's NPDES permit, each of these outfalls must be periodically sampled and characterized to determine the makeup of the discharge stream and to ensure that it complies with permit requirements.

The physical condition of the storm water collection system is similar to that of the process waste and sanitary sewer system, as all of these systems were created using much the same technology and materials over the same time frame. Infiltration of water from groundwater, process waste, sanitary sewer, and potable water systems cannot be ruled out, potentially introducing contaminants to the system. Detection of this low-level chronic introduction and release of contaminants is difficult because of the volumetric dilution from the single-pass cooling water. (Sect. 2.2.11.) Significant chronic discharges, however, are unlikely as these would show up in the environmental monitoring results. The Sink and Drain Study and Program (Sect. 2.1.5) provides further confidence in this hypothesis by providing additional assurance that the facility drains are now appropriately connected to either the storm water, process waste, sanitary sewer, or LLLW system.

Significant effort must be expended to keep up with compliance-related issues associated with these outfalls and their discharges. During the past few years, three liquid-feed dechlorinators have been installed on outfall pipes that carry large volumes of single-pass cooling water. Smaller, tablet-feeder dechlorinators have also been installed on numerous outfalls that convey smaller continuous or periodic

flows of cooling water. Because of the strict in-stream chlorine concentration limits imposed on ORNL by the NPDES permit, it is imperative that these waste water streams are chlorine free prior to their discharge (Sect. 2.2.11).

The last and probably the most significant environmental vulnerability for the storm water system is the continued potentials for spills from the inappropriate storage of chemicals and oil products adjacent to storm drains without proper secondary containment (see section on operational awareness program).

\subsubsection{Sanitary Sewage Collection and Treatment}

The sewage collection system consists of over 32,000 ft of pipe ranging in diameter from 4 in. to 12 in. Access to this system is obtained through 194 brick-and-concrete manholes. The system itself has grown as ORNL has grown. The early parts of the system, located roughly between First Street and Fifth Street, were constructed in 1943 when ORNL was built and consist primarily of vitreous clay pipe with packed joints and manholes constructed entirely of brick. The construction methods used in these areas reflect construction practices used when they were built, with some collection grid lines constructed from vitreous clay, concrete, cast iron, and polyvinyl chloride. Manhole construction also reflects this type of 
construction as some manholes are built entirely from brick, others are part brick and part concrete, and some are poured-in-place concrete. The newer manholes reflect the current practice of using precast units.

The system has been upgraded several times to address infiltration resulting from problems with the integrity of the manholes, lines, and other connections. During 1984 and 1985, approximately $60 \%$ of the sewage collection grid lines 6 in. and larger were rehabilitated using a then-new process called insituform. This proved not to be the ultimate solution to infiltration problems. In 1993, additional upgrades included cured-in-place lining in all sewer lines 6 in. and larger, sealing of all manholes with a high-build polyurethane, and other improvements. The detection of radioactive materials on occasion in the sewer treatment plant sludge provides additional evidence that there may be infiltration from the groundwater into the sewer system. The source of this infiltrated water (ground or potable) cannot be definitively determined at this time because of the unknown physical condition of the pipes and large amount of legacy contamination.

Efforts aimed at improving overall operations at the Sewage Treatment Plant continue with some notable successes. A portion of the digested sludge from the ORNL Sewage Treatment Plant is taken to the West End Treatment Plant in Oak Ridge where it is combined with sludge generated at the facility. The volume of sludge disposed of by this method is restricted by limits on the amounts of specific contaminants, but the process is viewed as a significant step towards resolving disposal issues. Future efforts will concentrate on locating and eliminating sources of the contaminants in question, many of which may still be entering the system through sections of building service feeder lines that could not be sealed with the lining process used during previous projects. Sections of these lines may need to be excavated and rebuilt to prevent the infiltration from occurring.

An ozonator system installed at the Sewage Treatment Plant is in operation. This system allows ORNL to eliminate the use of chlorine as a disinfection agent on the effluent stream leaving the plant. When properly installed, maintained, and operated, ozone systems are an effective disinfection system and are gaining favor at plants throughout the country. This system reduces the amount of chlorine in the receiving stream and will help ORNL to meet its NPDES permit compliance goals as well as reducing health and safety concerns associated with the storage and use of chlorine gas cylinders. The sewage analysis laboratory continues to be important in maintaining efficient plant operation by allowing realtime monitoring of process parameters. Treatment process operating parameter tolerances have been tightened, resulting in a higher quality effluent. This year's NPDES audit, performed by the state, once again recognized the positive impact of this laboratory on plant operations.

\subsubsection{Gaseous Waste Systems}

The 3039 stack ventilation system is operated by Duratek and consists of seven collection systems, each with its own underground and/or above ground ducting, fans, and controls. Five of these systems are designed to handle the cell-ventilation waste streams from limited-access areas and hot cells. The other two systems are designed to handle the off-gas from process equipment and laboratory experiments. The Oak Ridge Research Reactor pressurized off-gas system is not active and has been disconnected from the 3039 stack ventilation system.

Ventilation exhaust systems in laboratories, hot cells, and other facilities prevent human exposure to toxic and radioactive fumes, gases, and particulates. Many of the ventilation systems that exhaust radioactive containment areas have been upgraded by replacing corroded mild steel ductwork with stainless steel ductwork. Exhaust stack linings are made from materials that are not easily susceptible to corrosion. Radioactive containment ventilation systems at ORNL may use chemical recombiners, liquid scrubbers, charcoal filters, and high-efficiency particulate air (HEPA) filters to remove radioactive contamination 
from the air. The filtered air is then released to the environment through an exhaust stack. Contaminated absorbers and filters are disposed of as low-level radioactive waste.

The 3039 stack ventilation system, which was originally built in 1950, was extensively modified and upgraded in 1984 to increase its efficiency and reliability. In 1997 several of the cell ventilation blowers and the off-gas primary blower and backup fan were replaced to increase the system's reliability. Also in early 1997, a new scrubber solution tank and associated transfer equipment were installed meeting the requirements of the FFA for the LLLW system. Monitoring results indicate that effluents from the facilities are in compliance with regulatory limits.

A potential environmental vulnerability exists with this vent and cell off-gas system because some facilities and operations are unable to quantitatively validate that their discharges to the ventilation system meet the required BJC WAC for the system. In May 2000, BJC forwarded a draft Effluent Control Guidelines for Central Radioactive Gaseous Disposal Facility - Building 3039 at ORNL to UT-Battelle with a request for review and comment. The July 13, 2000, UT-Battelle response to BJC included substantive comments concerning the capability of UT-Battelle to comply with the guidance, particularly the measurement and recording of discharges from each of the facilities tied to the system. Most facilities do not currently have the capability to measure their discharges and instead use process knowledge to satisfy WAC. These comments have not yet been resolved between UT-Battelle and BJC.

Additional environmental vulnerabilities that may exist with the gaseous waste system involve the current physical condition of the system, the infiltration of water into ductwork and sumps, and the communication of potential contaminants to other systems (e.g., storm water). Evidence provided to the team indicated several issues. A significant portion of the gaseous system is composed of below-grade ductwork that operates at less than atmospheric pressure. As a result, groundwater (sources unknown) enters the ducts at various locations. This material is collected in various traps and drains and discharged to various collection systems. It is unclear if all of these discharges conform to the sink and drain program or have been identified and determined to be appropriate. Because all of the facility discharges to the system are prefiltered and the quantities of materials are small, the potential for materials to make their way to the environment might be expected to be small. These discharges most likely would not be detectable in light of the other volumetric masking and the large amount of legacy contamination in the general area.

\subsubsection{Solid Waste Disposal}

UT-Battelle is responsible for characterization, packaging, and certification of solid waste generated during operation of its facilities, including hazardous waste, mixed waste, low-level waste, and transuranic (TRU) waste. A BJC subcontractor, WESKEM, is responsible for transportation, storage, and disposition of these wastes. UT-Battelle is also responsible for the collection of sanitary waste generated at ORNL and transportation to the sanitary landfill.

Large numbers of B-25 boxes of legacy solid low-level waste (SLLW) are stored in BJC facilities at ORNL as well as in the main plant area. SLLW is currently stored in multiple facilities within Solid Waste Storage Area (SWSA) 5 and SWSA 6. By mid-2004, this activity will be consolidated in SWSA 5 because of the final capping and closure of SWSA 6. During FY 2001, the staged boxes of legacy waste within ORNL proper will be addressed. Approximately 200 of these boxes were dispositioned in FY 2000.

Remotely handled $(\mathrm{RH})$ radioactive wastes are not being disposed of in a timely manner. This creates potential environmental vulnerabilities and unnecessary exposures to staff. Continued storage of this waste in UT-Battelle facilities is having a programmatic impact as well. Impediments to disposition of 
RH waste include limited resources to prepare characterization and certification documents, uncertain packaging requirements, evolving transportation requirements, suspension of Interim Waste Management Facility operations, minimal shielded waste storage facility capacity, and no currently approved off-site disposition pathway.

Hazardous wastes may be accumulating now in Satellite Accumulation Areas (SAAs) in a manner that may be creating other safety and health vulnerabilities. During several facility walkdowns, "less than 55gallon quantities" of wastes were noted in some laboratories and in SAAs that had rather old generation dates (as old as 1991). While the storage of these wastes complies with regulatory requirements, good chemical safety practice calls for disposal of these materials in a more timely manner. Continued storage of small quantities of various wastes creates potential fire hazard issues as well. This issue is similar to issues associated with larger quantities of legacy wastes and should be addressed through those corrective actions.

\subsubsection{Vacuum System Moisture Traps}

All vacuum systems that service laboratories and operations have traps that remove moisture from the vacuum lines before being exhausted into the environment. The moisture collected in the traps contains not only water but other materials that are pulled into the vacuum system along with the surrounding air. The materials can be anything that has volatilized or accidentally or intentionally pulled into the lines. Therefore, process knowledge indicates that liquids that are collected in the vacuum system traps may contain any material that is available for use within the facility serviced by the vacuum system. Sampling of moisture trap contents at PNNL indicates that hazardous and mixed wastes may be collected in these traps, especially when there is readily available access to the vacuum system ports in laboratory chemical hoods and there are no controls on the access to the vacuum system ports.

Review of the sink and drain protocol and database does not provide evidence that vacuum system moisture trap discharges were specifically considered. It is believed that the moisture traps drain to sumps that are connected to the PW system, but this was not verified in all buildings.

\subsubsection{Single-Pass Cooling Water}

An estimated $800 \mathrm{Mgy}$ of potable water is used for single-pass cooling of equipment and facilities. This cooling water is discharged to storm water and PW systems in large volumes and to the sanitary sewer in much smaller volumes. This large volume of single-pass cooling water presents a number of environmental and operational issues: volumetric masking of storm water and PW system effluent concentrations; chlorine control and monitoring of storm water outfalls; ineffective and inefficient use of natural resources; and enabling communication and transport of contaminants among storm water, sanitary sewer, process waste, and groundwater.

- Volumetric Masking. Figure 5 presents an overall water balance for the ORNL site prepared as part of the NPDES permit application. The issue of volumetric masking is demonstrated in analyses performed for the PW system. A similar analysis can be performed for the storm water and sanitary sewer, but was not conducted as part of this effort. This analysis shows that the PW system outfall concentrations meet the NPDES permit limits, and samples taken at seven of the major manholes show concentrations less than the WAC limit. However, UTBattelle generators do not have data (flow and concentration) at the point of discharge to the PW system and rely on generator training and administrative controls to satisfy the WAC. Also, UT-Battelle does not periodically assess the effectiveness of these administrative controls. Based on a survey of division environmental protection officers (EPOs), it was estimated that from 100 to $140 \mathrm{Mgy}$ of single-pass cooling water is discharged to the PW system from UT-Battelle facilities. If this large amount of "clean" single-pass cooling water 
is subtracted from the PW system, the concentrations at the manholes begin to approach the WAC limits, and discharges at the PW treatment plant outfall could exceed NPDES limits. While it is likely that a major fraction of the contaminant load at the manholes results from DOE EM-related activities (building sumps, contaminated groundwater collection, etc.), UTBattelle has no hard data on its discharges to the PW system and would be unable to demonstrate that its operations were not the cause of elevated manhole concentrations.

- Chlorine Control and Monitoring. Because the single-pass cooling water originates in the potable water system, it contains chlorine, which may not be discharged into the storm water system without treatment under the NPDES permit. Consequently, dechlorination stations have been established at 22 locations, and a chlorine monitoring program has been established to validate compliance with the discharge limits in the NPDES. Some attempts have been made to limit or consolidate these discharges to the storm water system; however, these attempts have met with little success because of inadequate funding. The costs associated with the chlorine monitoring program include equipment, maintenance, operating materials, monitoring, reporting costs, and liability if systems fail. Organizations who don't have the money to replace cooling units with closed-loop systems are relying on the overhead-funded chlorine program. No comprehensive cost-benefit analysis of this situation has been conducted.

- Ineffective and Inefficient Use of Natural Resources. The widespread use of potable water for single-pass cooling has been discouraged for many years throughout the world. Potable water is a natural resource that has received significant protection through the Safe Drinking Water Act and other regulatory schemes. The use of large volumes of potable water for single-pass cooling at ORNL does not seem to be consistent with the national and international practice. This region of the country has abundant water resources; however, the costs to produce the water and the environmental impact from by-products of production (e.g., electricity generation, chemical production, waste disposal) are substantial. No Comprehensive cost-benefit analysis of this situation has been conducted. 


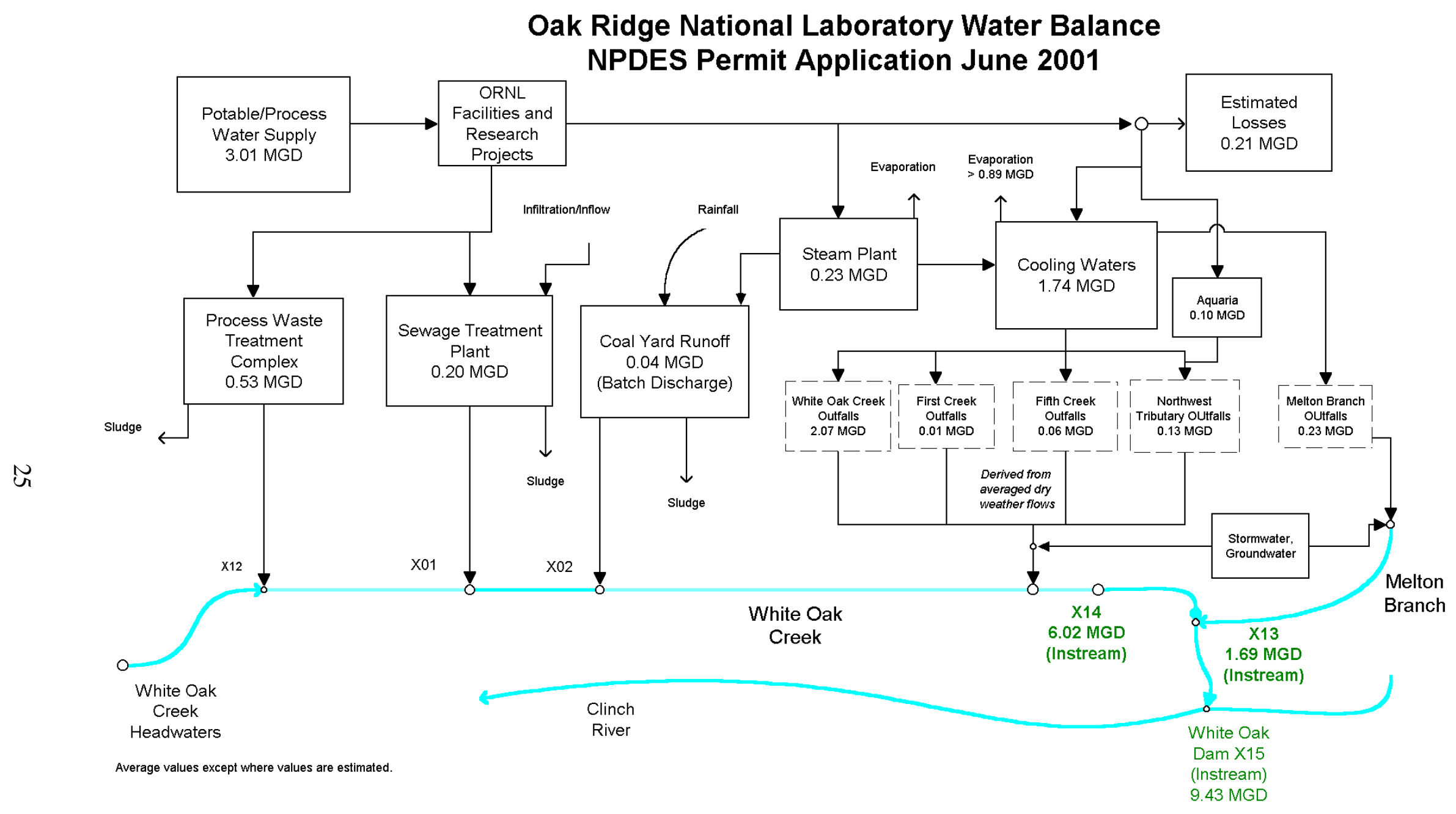

Fig. 5. ORNL water balance. 
- Communication and Transport of Contaminants. The large volume of single-pass cooling water may be enabling communication and transport of contaminants among storm water, sanitary sewer, process waste and groundwater. As stated previously, the storm water, sanitary sewer, and PW systems are of questionable integrity especially between the buildings and the manholes. The large volume of cooling water provides an additional hydraulic gradient that may enable transport or communication between systems, depending on the locations of the piping. Infiltration into the sanitary sewer from unknown sources is evidenced by periodic detection of radioactive materials in the sanitary sewer sludge. The leakage of the cooling water from these systems also likely adds to the volume of groundwater and may increase the hydraulic gradient in ways that enhance transport of legacy contaminants through groundwater and surface water.

\subsubsection{Surface and Subsurface}

During early operations, a significant amount of radioactive and chemical contamination was introduced to the surface and subsurface regime at ORNL. This contamination resulted from a variety of sources, including pipeline and tank leaks, spills, leakage from unlined impoundments, etc. Many contaminated sites have been identified and are being or will be addressed by the DOE EM program. However, it is likely that a number of areas with contaminated soil and / or groundwater have not been documented. This identified and unidentified legacy contamination presents the following environmental vulnerabilities.

Excavation activities are required as part of normal plant maintenance, repair, and construction activities. An excavation permit process is in place to identify existing subsurface utilities, pipelines, and structures. The permit process also includes review by BJC and its subcontractors to determine if any LLLW or PW system pipelines or legacy contamination areas exist in the vicinity of the proposed excavation. When these conditions are identified appropriate action can be taken to relocate the excavation, or if required, implement appropriate worker safety, waste management provisions, and environmental protection. However, these measures significantly increase the cost of the excavation process making it more difficult to fund required facility maintenance and improvements. Encountering unknown legacy contamination during excavation activities presents the potential for worker exposures and the development of new routes of entry for storm water and/or groundwater to disperse contaminants into the environment.

Significant evidence exists that vegetation, insects, and animals provide a pathway for the migration of surface and subsurface legacy contamination. Most of this migration is caused by the availability of legacy materials in the environment that may be transported by these vectors. Groundwater and soil contamination in the central part of ORNL are the likely cause of contaminated trees and plants that have been discovered in the past and continue to be identified. In addition, the existence of contaminated settling ponds (south of 3517) contribute to the easy access of contaminated mud and small plants used in wasp and bird nests that have also recently been found to be contaminated. Some animals have also been found to be contaminated (e.g., frogs and turtles).

Actions have been taken to control animal access to contamination areas, such as use of overhead wires to keep geese out of contaminated ponds and fences to keep deer out of contaminated areas. Programs are also in place to identify, monitor, and remove plant and animal contamination, such as monitoring deer and turkey taken during Oak Ridge Reservation hunts and geese when they are tagged. It is also anticipated that remedial actions such as the surface impoundments closure will help to eliminate contamination sources. However, these efforts are only partially successful as indicated by the recent contamination incidents. 


\subsection{Past Vulnerability Reduction Initiatives}

In reviewing the Laboratory infrastructure and programs as a part of this assessment, it was noted that a large number of environmental vulnerability reduction activities have already been implemented. Most of these efforts have been reactive, externally driven, and focused on regulatory compliance only. It was not possible from the information developed during this FEVA study to quantify the degree of environmental vulnerability reduction achieved; however, it is fair to say that these efforts have had a significant impact.

Examples of vulnerability reductions achieved through the DOE EM program compliance with the CERCLA as implemented by the FFA include

- Homogeneous Reactor Experiment pond stabilization,

- Solid Waste Storage Area 4 and 5 seeps collection and treatment,

- $\quad$ pit 1 In-situ vitrification,

- core hole 8 plume mitigation,

- cooling towers demolition,

- isotopes facilities deactivation,

- process waste settling basin remediation,

- old hydrofracture tanks waste removal/stabilization,

- old hydrofracture pond stabilization,

- surface impoundment operating unit A, C and D ponds stabilization,

- Gunite Tank waste removal,

- 3001 canal cleanup and grouting,

- 3505 decontamination and decommissioning,

- Molten Salt Reactor Experiment project decommisioning, and

- partial integrated process development facility cleanup.

Examples of vulnerability reductions achieved for gaseous waste systems compliance include

- building off-gas renovation, and

- central off-gas system renovation.

Examples of vulnerability reductions achieved for lliquid waste systems compliance include

- Federal Facility Agreement program (tank inspection, testing, tank closure),

- Bethel Valley evaporator service tank sludge removal,

- surface impoundment deactivation,

- nonradiological process waste treatment plant upgrades,

- liquid low-level waste system upgrades,

- process waste capacity improvements,

- insituforming of process waste/sanitary waste lines, and

- $\quad$ sanitary sewer system upgrades.

Examples of vulnerability reductions achieved through regulatory compliance and other programs include

- environment, safety, health, quality and infrastructure upgrades;

- High Flux Isotope Reactor process waste line replacement; 
- aging equipment and hot cell study;

- $\quad$ sink and drain study;

- stack and vent study;

- National Emission Standards for Hazardous Air Pollutants (NESHAPs), National Pollutant Discharge Elimination System (NPDES), and Resource Conservation and Recovery Act (RCRA) Permits;

- environmental monitoring upgrades;

- chlorine gas inventory reduction Building 2643;

- underground storage tanks program;

- $\quad$ spill prevention control and countermeasures plan; and

- chlorinated fluorocarbon chiller replacement program.

\subsection{Current Vulnerability Reduction Initiatives}

FEVA identified a large number of vulnerability reductions that are currently under way, including a number of initiatives undertaken by UT-Battelle that are proactive, best-management-practice driven. Again, information is not available to quantify the degree of vulnerability reduction expected to be achieved.

UT-Battelle best practices initiatives include

- excess chemicals inventory reduction,

- Integrated Safety Management System initiatives-work planning,

- Facility Use Agreements,

- planned waste certification surveillance program upgrade for liquid waste,

- below-ground strategic facilities infrastructure analysis,

- integrated hot cell facility business plan,

- operational awareness program,

- SBMS,

- Performance Based Management System (PBMS), and

- hazardous waste transition pilot.

Remediation-related initiatives being conducted by BJC for the DOE EM Program include

- $\quad$ SIOU B pond,

- tank W-1A removal,

- Gunite Tank grouting,

- 3505 decontamination and decommissioning,

- Federal Facility Agreement tank remediation,

- Bethel Valley shallow groundwater study, and

- transfer of excess UT-Battelle facilities.

Compliance-driven initiatives conducted by ORNL include

- annual sink and drain recertification,

- groundwater protection plan upgrade, 
- suspected leakage investigations,

○ Outfall 207 south of 3500

- 3000 area north of 3047

○ bank of White Oak Creek near Outfall 302

- Outfall 204 south of 2531

- spill prevention control and countermeasures plan,

- storm water pollution prevention program,

- radiological monitoring plan for NPDES outfalls,

- chlorine control monitoring of NPDES outfalls,

- biological monitoring and abatement program,

- radiological NESHAPs monitoring and reporting, and

- stack and vent recertification/annual air emissions source review.

\subsection{Vulnerabilities Noted During Facility Assessments}

\subsubsection{Priority 1 Facilities}

The Priority 1 facilities were "walked down" by members of the team. The specific vulnerabilities are identified along with a description of each facility in the following section. The results of the individual walkdowns are maintained in the FEVA file. Essentially all of the vulnerabilities identified were known and pointed out by the facility personnel and can be summarized as follows.

- All of the buildings are over 30 years old and have general environmental vulnerabilities such as the presence of lead-based paint, polychlorinated biphenyl (PCB) ballasts, and asbestos typical of buildings this age.

- The facilities have varying degrees of deterioration of infrastructure (pipes and vents) and structure (roof leaks, rust, etc.).

- The facilities contain varying amounts of radioactive and chemical contamination in containment areas such as cells, rooms, and equipment that are surveyed regularly, and most rely on the operation of the BJC central off-gas system to provide negative ventilation.

- Almost all the facilities discharge liquids to the PW system through connections with unconfirmed integrity presenting the potential for leakage of contaminants to the environment.

- Several of the buildings have below-grade pits that collect rainwater or groundwater inleakage that are pumped or drained regularly but present the potential for leakage of contaminated liquids to the environment.

\section{Building 2026}

The Radioactive Materials Analytical Laboratory (RMAL), Building 2026, is physically located at the intersection of Hillside Avenue and Third Street and is operated by the Chemical and Analytical Sciences Division. The facility is a two-story block structure, consists of steel framing for all load bearing walls with 12" concrete blocks used for exterior walls and 8" concrete blocks for most interior walls. Highdensity concrete was used in areas around the cell windows where workers would spend most of their time performing routine activities.

The RMAL facility receives, stores, assays, and disposes of a wide variety of radioactive materials. Assay operations include dissolutions, dilutions, separations, followed by physical, chemical, and radiochemical 
examinations of individual samples. The RMAL provides a wide range of analytical chemistry support, including inorganic, organic, and radiochemical analyses to both the R\&D divisions and plant operations.

The RMAL facility was constructed in 1964 (additions added in 1966 and 1985) and provides 22,600 sq. $\mathrm{ft}$. of laboratory and office space dedicated to the application of general analytical chemistry to radioactive materials. This facility is equipped with special containment and ventilation systems to handle radioactive materials with high gamma dose (hot cells) and high levels of alpha (glove box system). To mitigate cross contamination, the facility is designed to handle lower levels of radioactivity in laboratories segregated from areas that handle higher contamination levels. The facility was recently upgraded to include a new radioactive liquid waste system that meets current regulatory requirements; the facility is fully equipped to handle the packaging and disposal of radioactive solid waste.

This assessment identified several vulnerabilities that are summarized as follows:

- The northwest exterior of Building 2026 has an underground concrete filter exhaust pit for the main exhaust system of the building that accumulates water that could leak to the environment.

- The main exhaust stack has a drain in the bottom that was recently rerouted to the PW system.

- The old LLLW storage tank of uncertain integrity, currently under the responsibility of BJC, contains 3-50 gal of sludge that contains PCB oil and about $5 \mathrm{lb}$ of elemental mercury.

- Numerous drain systems connecting to the PW system have uncertain integrity, resulting in the potential for leakage to the environment.

\section{Building 3019A}

Building 3019A, the Radiochemical Development Facility, is a vintage Manhattan Project complex that is more than 55 years old. The primary mission of Building 3019A is a DOE storage facility for ${ }^{233} \mathrm{U}$. Preparations are currently under way to begin inspecting (and repackaging as required) the ${ }^{233} \mathrm{U}$ containers. Significant amounts of fission product and TRU contamination exist in the building.

Much of the original structure and add-on floors are made of concrete that provides some measure of containment. Many of these floors are stainless-steel lined to ensure containment where the potential for higher levels of contamination exist, such as airborne contamination areas. However, many other areas where lower levels of contamination are present have no liners. The building is equipped with several HEPA filter systems that discharge to a local stack and to the central ORNL stack. The building is connected to the LLLW and PW systems as well as to the sanitary and storm drain systems.

A chemical explosion occurred during 1959 in Building 3019, process cell 6. This explosion occurred while decontaminating a process tank that recently had been used for plutonium-bearing liquids. Although no one was injured in the explosion, plutonium contamination was released and was spread throughout Building 3019 and outdoors, covering areas around the building in all directions and including only buildings immediately to the south and east (eastern contamination extended to and included the Oak Ridge Research Reactor, Building 3042). There was no release off-site and continued vigilance is required in maintaining surface bonds and controlling maintenance/modification work at the facility. Other minor, localized releases also have occurred within Building 3019 over the years of continued facility operation that posed no long-term effects. 
This assessment also included Building 3100 (storage vault), Buildings 3091, 3108, and 3121 (off-gas filter houses), Building 3020 (off-gas stack), and Buildings 3123, 3131, and 3146 (standby power generators).

This assessment identified 12 specific vulnerabilities that are summarized as follows:

- A deteriorating out-of-service contaminated conveyor is located on the building roof.

- An external 1950's vintage 36-in-diam mild steel cell off-gas (COG) duct shows signs of deterioration;

- Groundwater leaking into the contaminated filter bunkers 3091 and 3108 requires regular draining.

- An out-of-service, underground LLLW drain line has left legacy contamination in the 3020 stack area requiring enhanced S\&M to prevent the spread of contamination.

- The exterior south wall is a three-story block structure with no anchoring along its elevation, making the wall vulnerable to seismic and wind events.

- Three external vessel off-gas (VOG) lines (that are highly contaminated internally) show signs of deterioration.

- The VOG is interconnected to the COG, providing the potential for exchange of unfiltered off-gas between the systems.

- Inactive Building 3121 (filter house) is sealed but is highly contaminated inside.

- Sanitary, storm, and process waste drains are made of vitrified clay or cast iron and are presumed to leak to the environment.

- Perchlorates above the action level concentrations have been found in the off-gas manifold in adjacent 3019B (managed by BJC) that is connected to and served by the 3019A laboratory off-gas (LOG) system. Some perchlorate contamination has been detected in the 3019A LOG ducts slightly above the ORNL threshold.

- P-24 tank (located in a mostly below-grade pit) contains approximately 15,000 L of nitrate solution containing two metric tons of thorium contaminated with ${ }^{233} \mathrm{U}$.

- Manholes adjacent to the building contain low levels of contamination.

\section{Building 3025E}

The facility was constructed in 1950 and is currently about 70-80\% utilized. Over the past 34 years smaller quantities of radioactive materials have been used. Present radioactive inventory is approximately $3600 \mathrm{Ci}^{60} \mathrm{Co}, 105 \mathrm{Ci}^{54} \mathrm{Mn}, 77 \mathrm{Ci}^{55} \mathrm{Fe}$, plus smaller quantities of isotopes from induced activity during bombardment of structural material test specimens.

A remote storage facility was added in 1958 and decommissioned in 1985. Cell 6 was enlarged and upgraded to a sealed cell in 1958. Sealed storage wells were installed in 1985. A major upgrade of the LLLW system was completed in 1998.

The assessment identified several vulnerabilities that are summarized as follows.

- Sealed storage wells contain internal contamination but the wells are dry.

- Request has been submitted to replace deteriorated steam piping.

\section{Building 3027}

Building 3027, the Nuclear Materials Storage Vault, was constructed in 1980. The building is used for the storage of Security Category III radioactive materials. No materials processing is performed in the 
building and fissionable materials must be contained by two sealed barriers at all times. The materials stored in the vault are inspected weekly.

The building contains eight rooms and is constructed with an 18-in. concrete slab, reinforced 18-in.chthick walls, and a 10-in. reinforced concrete roof. The building was designed and constructed to withstand both a $0.15 \mathrm{~g}$ earthquake and a $350 \mathrm{mph}$ wind. The rooms are equipped with drains that are piped to a steel storage tank located in a below-grade pit. The building is ventilated to the central off-gas system.

The assessment identified two specific vulnerabilities that are summarized as follows.

- The drain lines from the rooms to the storage tank are single-contained lines located below the building slab that do not have integrity checks performed regularly.

- Confirmation of integrity of two sealed barriers for fissionable material as described in the facility safety documentation needs to be performed by the Chemical Technology Division(CTD).

\section{Building 3047}

The Radiochemical Development Laboratory (RDL), Building 3047 (excluding 3047A), is operated by the ORNL CTD. This facility is currently utilized for the receipt, purification, research, and storage of radioactive materials. Current plans call for these activities to continue indefinitely in support of the national effort in radioisotope production. The RDL is a research, operations, and storage location that can be utilized by other divisions and facilities as needed for this type or work. The facility has been operating continuously since construction was completed in 1962.

Building 3047 is a three-story, structural-steel-frame building with 8-in.-thick concrete-block exterior walls reinforced in every other course with nine-gauge Dur-o-wall wire. The structure consists of moment-resistant frames; three bays are in the west end and six bays are in the east end. These bays are spaced at approximately 20 -ft centers and are connected at the roof level by 8 -in. tie beams over an expansion joint. East-west beams tie into the cell bank mass as do interior columns.

The building is divided by use for purposes of confinement. The primary confinement areas are used for isotope production and other operations in which the radioisotopes present have a greater inhalation-dose consequence, which can come from either specific activity of the isotope (for example, the transuranic alpha materials) or a greater quantity of the isotope being present. Greater gamma-activity (penetrating radiation) or higher energy beta-emitting isotopes require greater shielding; hence, the use of the concrete- or water-shielded hot cells. Where less shielding is needed, glove boxes and other enclosures, such as self-contained units, are utilized.

Secondary confinement areas are maintained surrounding the primary confinement areas. In addition, operations with lesser quantities or with radioisotopes of less hazardous consequence are carried out in secondary confinement in hoods or in open radiochemical laboratories.

The assessment identified several vulnerabilities that are summarized as follows:

- A seismic evaluation indicated that portions of the above-ground off-gas system and glove boxes may be vulnerable to earthquakes or wind.

- A HEPA filter housing on the roof (AJ-102) shows signs of deterioration and presents the potential for leakage of contaminated off-gas. 
- A planned upgrade to provide the capability to transport liquid waste to the LLLW system will utilize a portion of an inactive LLLW drain that may provide a pathway to the environment and may present regulatory issues.

- A significant amount of solid RH LLW has accumulated in the cell charge area, presenting potential combustible material and as low as reasonably achievable (ALARA) problems.

- Several opportunities for "housekeeping" improvements were noted.

- Process water outlets in cells and glove boxes present a low probability potential for contaminant migration to the potable water system if a backflow preventer were to fail.

- Interface agreements have not yet been established for changing filters in a HEPA unit for the 3047 hot off-gas system that are located in Building 3028 (managed by BJC).

- Equipment needed to load spent fuel cans from 3047 into storage wells at SWSA 5 is not currently available and is delaying needed facility upgrades to meet programmatic needs.

\section{Building 3525}

Building 3525, constructed in 1963, is a two-story brick building with a partial basement. The first floor houses the primary containment-shielded cell complex, consisting of three hot cells arranged in the form of a "U." The hot cells are constructed of 3-ft-thick barites concrete walls and compatible oil-filled, leadglass viewing windows, creating essentially a leak-tight barrier. The remainder of the laboratory outside the hot cell complex is subdivided into the charging area, the equipment maintenance air lock areas, the operating area, the truck unloading area, the photographic rooms, the main change room, and the rooms housing supporting mechanical equipment. Located on the east side of the truck unloading area is a small laboratory which houses the core conduction cooldown test facility. The core conduction cooldown test facility is used to test radioactive samples under controlled thermal conditions while monitoring the samples to determine the release of radioactive materials.

The "processes" performed in the facility consist of receipt and handling of irradiated materials (fuel or nonfuel, typically as experimental capsules) in shielded casks; transfer of material into and out of the hot cells; capsule disassembly; nondestructive and destructive testing of irradiated materials; packaging and shipment of irradiated materials (on-site or off-site); waste packaging for disposal; maintenance of remote equipment; and decontamination of the facility and equipment. Examination and testing activities include metrology; metallographic sample preparation by sectioning, grinding, and polishing; optical and electron microscopy; mass spectrometry of fission gases; gamma spectrometry; and other physical properties evaluations as appropriate to the experimental objectives of a particular program.

The assessment identified several vulnerabilities that are summarized as follows:

- An underground oil storage tank is buried on the west exterior of the building that is assumed to be empty with no radiological concerns.

- The first floor mechanical room houses a chiller that utilizes ethylene glycol and has drains that are connected to the PW system.

- An inactive LLLW storage tank (F501) isolated from the building and decommissioned in 1996 and now under the responsibility of BJC contains approximately $20 \%$ by volume of residual LLLW contaminated with PCB.

- An inactive process waste tank (F202) that was tied into the building hot off-gas system is the responsibility of UT-Battelle.

- A contaminated sump in the basement of the building is drained manually into 55-gal drums for transport to treatment. 
- The basement has an equipment access pit with a drain routed to the sump noted in the previous item.

- The building has drain systems connecting to the PW system with uncertain integrity, presenting the potential for leakage of contaminants to the environment.

\section{Building 4500S}

Building 4500 South is a two-story building with basement and attic levels. Built in the early 1950's the building consists of a main area with four wings connected to the main area. The building consists primarily of offices, laboratories, storage areas, maintenance shop areas, a mailroom, a canteen area, and utility equipment areas. Primary utilities include sanitary water and sewer; process water and sewer; steam and condensate return systems; compressed air; electrical utilities; and heating, ventilation and air conditioning systems. The facility contains numerous hoods and other sources that are vented locally. A radioactive "hot" drain no longer in use is in place and interconnects the service chases serving the firstand second-floor laboratories

The assessment identified several vulnerabilities that are summarized as follows.

- The 45-year-old facility contains asbestos, PCB lighting ballasts, mercury switches, and radioactive and chemical contaminated drains that could be sources of release of contaminants to the environment.

- Survey, interviews, and data indicate a large volume of single-pass cooling water and a small but unquantified amount of chemical and radiological materials are discharged from $4500 \mathrm{~S}$ to the process waste drain system with potential leakage to the environment.

- A large inventory of chemicals presents a significant source term a portion of which could be released to the environment in the event of fire and/or sprinkler system discharge.

- The presence of chemicals in hoods with open drains presents the potential for spills and introduction of prohibited materials into the process waste drains.

- Handling accidents during packaging and transport of LLLW present the potential for release of contaminants to the building and to the environment.

- A fresh stain was noted below a process waste drain, indicating previous water leakage.

- A storage area in the attic of E-wing was noted to have chemicals stored without secondary containment that could present the potential to release contaminants.

- Several SAAs contain hazardous chemicals dating back 5 years or more presenting potential chemical management safety concerns.

\section{Building 4501}

Building 4501 is a radiochemical facility containing offices, chemical laboratories, hot cells, and a glove box facility. The facility is primarily occupied by personnel of the CTD and, on an ongoing basis, supports a variety of research and development efforts including, but not limited to, reactor safety, separations chemistry, materials research, and fundamental chemistry. A new process to convert ${ }^{233} \mathrm{U}$ adsorbed on NaF traps as part of the Molten Salt Reactor Experiment (MSRE) D\&D is undergoing final test and checkout prior to an operational readiness review.

Building 4501 is a steel, concrete, concrete block, and brick building. Interior partitions are made primarily of poured concrete and concrete block faced with transite, gypsum block, or steel paneling. The building was constructed in 1952 and has four floors. Except for the first floor, there are interior access connections from Building 4501 to Building 4505 through hallways and stairwells. 
The basement floor contains laboratories, shop areas, cell ventilation ducts, and storage areas. Centrally located on the first floor are four hot cells surround by support laboratories and operating areas. The outside part of this floor contains chemical and radiochemical laboratories and office space. Immediately above the hot cells and surrounding laboratories on the second floor is the high bay area (contains chemical and radiochemical laboratories and office space). The third floor is the attic area and provides space for building utilities, ventilation fans, and controlled storage. The roof of the building contains several exhaust stacks associated with building ventilation systems.

The assessment identified several vulnerabilities that are summarized as follows:

- Water potentially contaminated with mercury from legacy spills infiltrates into the basement and is collected in a large sump that discharges to the storm water.

- A number of other sumps with unknown integrity exist in the basement.

- The facility contains piping that is in poor condition and in need of replacement.

- The facility contains a significant amount of contaminated material and equipment that should be removed.

- Housekeeping can be greatly improved in the basement and attic.

\section{Building 5505}

Building 5505, the Transuranium Research Laboratory serves as the center for cooperative research and analytical development for ORNL staff, university participants, and scientists from other laboratories. Research involves the chemistry, physics, and material science of actinides and their compounds, to provide fundamental and technological information, as well as a platform for the development of analytical instrumentation. Fundamental research in inorganic mass spectrometry is also performed.

Construction of the facility was completed in 1967. The building is a one-story structure with an equipment room located on the roof. The building is constructed of reinforced concrete with exterior walls of concrete block faced with brick. The equipment room is of steel frame construction with exterior walls of uninsulated aluminum panels. The laboratories are located back-to-back in the central portion of the building and are separated by a central corridor providing controlled access to each laboratory for transfer of radioactive materials. The offices occupy the north, west, and south perimeters of the building and are across a corridor from the laboratories.

The facility is served by plant electrical, steam, potable water, chilled water, compressed air, natural gas, sanitary sewer, and PW systems. Storm drains receive rainwater roof from drains, building foundation drains, and steam condensate drains. Currently no radioactive liquid waste is generated in the facility, but provisions are in place for a radioactive bottling station if needed. The facility maintains negative pressure through the interaction of the laboratory and office air supply system, the laboratory exhaust system, and the glove box exhaust system.

The assessment identified several vulnerabilities that are summarized as follows:

- There has been some seepage into the building under periods of heavy rain, although the amount of moisture present has never been considered excessive and has never resulted in the spread of contamination.

- The potential for introduction of radioactive material into the PW system is extremely low and has been addressed administratively by installing plugs and/or covering drain access in hoods where radioactive material may be present, in addition to posting nonradiological process drain as applicable. 
- The process lines appear to be in good shape (encased in concrete) from the building to the process waste manhole on the west side of the building, although little information is available on the lines from the manhole to the Process Waste Treatment Plant.

- Radioactive material storage wells in the southeast of the storage vault have been accessed, surveyed, and confirmed to be free of contamination

\section{Buildings 7920 and 7930}

Building 7920 and 7930 (REDC) are centrally located near other occupied facilities in the ORNL 7900 building area that includes the REDC, the HFIR, miscellaneous process/operations/storage buildings, office buildings, and trailers. Since the mid 1960s the REDC has been the production, storage, and distribution center for the heavy-element research program of DOE.

Building 7920 is a two-level structure with high bay areas housing a heavily shielded, reinforced concrete hot cell bank, hot cell support areas, laboratories, and an office wing. Target rods containing americium and curium are remotely fabricated in Building 7920, irradiated in the adjacent HFIR, and then processed in the hot cells for separation and purification of the heavy actinide elements. Mark 42 target assemblies that were irradiated at the Savannah River Site are also processed in the hot cells for separation and recovery of high-purity ${ }^{243} \mathrm{Am}$ (as well as ${ }^{242} \mathrm{Pu}$ and ${ }^{244} \mathrm{Cm}$ ) for shipment to Los Alamos National Laboratory.

Building7930 is a three-level structure with a high bay area housing a hot cell bank, hot cell support areas, laboratories, and an office wing. It was constructed in the mid1960s to develop and demonstrate methods for the remote refabrication of thorium and uranium oxides into fuel for recycle to power reactors, but processing equipment was not installed, and the facility was never used for the intended purpose. From about 1970, the facility has been involved in handling and processing ${ }^{252} \mathrm{Cf}$ and ${ }^{248} \mathrm{Cm}$ and conducting associated activities such as sales and loan program and user facility operation.

Both these buildings are served by many of the same utility supply systems and support organizations that serve other facilities in the 7900 building area. A few shared interfaces include electric power, demineralized water is supplied from HFIR, compressed air systems are supplied by the REDC air compressor units, terminals for pneumatic and hydraulic rabbit transfer system are connected to transfer system terminals and the HFIR, and underground line connections to the centralized ORNL liquid waste collection/storage systems.

The assessment identified several vulnerabilities that are summarized as follows:

- Adjacent Building 7935 (managed by BJC) utilizes administrative control for a diversion valve that could discharge process waste liquids to a drain that is suspected to have been damaged during construction activities.

- The Melton Valley line item replaced and /or upgraded many of the waste lines such as the LLLW lines in 1996. Many of the old systems abandoned in place are contaminated.

- One misrouted line was identified in Building 7920 and was immediately corrected

\subsubsection{Priority 2 Facilities}

As noted in Sect. 1.2, a total of 64 facilities were identified through the Priority 2 facility screening process. Most Priority 1 facilities would also be identified through this screening process, but they are not 
included in this discussion. The 64 Priority 2 facilities were "walked down" by members of the team with a focus on the facility characteristic (such as presence of a high contamination area) that was the basis for its being "screened" for evaluation. The results of the individual walkdowns are maintained in the FEVA file. A summary of the findings follows.

\section{Facilities with High Contamination Areas}

Seven facilities (3091, 3108, 3121, 3503, 4505, 4508, 9204-3) were initially identified that contained high contamination areas as reflected in the ORNL radiation work permit system. Three of the facilities, 3091, 3108 , and 3121, are filter houses that are associated with 3019 and were reviewed in the Priority 1 walkdown of that facility. The high contamination areas in these Priority 2 facilities are typically sealed equipment or rooms contained within the building. In general, all these facilities presented the vulnerability that contamination might be released to the environment through unidentified leaks or in the event of off-normal conditions, such as high wind, earthquake, fire, or sprinkler activation.

\section{Facilities with other than "Industrial/Generally Accepted" hazard rating}

Four facilities were identified including three designated as "accelerator" (3003, 6000, and 6010) and one designated as "low" (9204-3). No unusual vulnerabilities were identified at these facilities.

\section{Facilities that Require Hazards Surveys and Assessments under DOE Order 151.1}

The hazard assessments (HAs), hazard surveys, and emergency action level (EAL) manual maintained by the Emergency Preparedness Department were reviewed, and five facilities (2547, 2643, 6000, 6005, and 7040) were identified. The HAs are reviewed each year and the EALs and hazard surveys are reviewed every three years. When new activities or major changes to ongoing activities are planned, the local emergency manuals, hazards surveys, HAs, and EALs are revised as required. It was observed during the course of this review that a number of changes had occurred at these facilities that were not reflected in the current documentation. Following is a summary of the results of the review.

- The chlorinator building (2643) and the Gas Cylinder Storage Facility (7040) no longer contain chlorine inventories that would require these facilities to have HAs or EALs. The field walkdown verified that the chlorination system has been replaced with an ozonation process. The EAL for 2643 has been removed from the EAL Manual and the EAL for 7040 is in the process of being removed from the EAL Manual.

- The Isotopes Separation Facility (9204-3) inventory of cadmium oxide had been reduced below the threshold screening quantity. The selenium dioxide inventory in this facility is still above the screening threshold. The draft hazard survey now states that a waste requisition has been completed to remove the selenium dioxide and list it as a RCRA waste.

- The machine maintenance shop (2547) contains inventories of cyanide-based plating compounds that exceed the screening thresholds. These materials are currently being evaluated for outside sale.

- The Hollifield Radioactive Ion Beam Facility (6000) and associated gas compressor house (6005) contain quantities of sulfur hexaflouride that exceed the screening criteria. The ORNL hazard survey screens out the sulfur hexaflouride using the criteria found in DOE Guidance to DOE Order 151.1, including physical containment, administrative controls, and that the hazard is localized (asphysixiation hazard). 
In addition, a check was made on the hazard documentation associated with the approx. 40,000 lb inventory of elemental mercury located at 7603 to support SNS equipment testing. Based on the degree of containment provided in the facility and the nature of the mercury, it was determined that a hazard screening would be prepared to evaluate the impact of a fire in the facility. The prefire plan located in 2500 did not identify the presence of the mercury inventory in 7603, but the plan was immediately revised.

\section{Facilities that Discharge to the Central Off-Gas System}

A review of draft Effluent Guidelines for Central Radioactive Gaseous Disposal Facility - Building 3039 at ORNL identified seven facilities that discharge to the COG system $(3036,3121,3503,3508,3550$, $4500 \mathrm{~N}$, and 4505). No unusual vulnerabilities were noted at any of these facilities. As indicated in Sect. 2.2.4, ORNL generators are generally not able to quantitatively defend their ability to meet the WAC other than through a "process knowledge" approach.

\section{Facilities that Discharge to the ORNL Liquid Waste System}

Several documents that identify facilities with connections to and/or discharges to the ORNL liquid waste treatment system were reviewed.

Three facilities (3074, 3503, and 4500 N) were identified in the Annual LLLW Generation Survey maintained by Duratek as discharging to the LLLW system. Two facilities, 3074 and $4500 \mathrm{~N}$, discharge their materials to the LLWS via transport systems ("dumpster" tank for 3074 and "bottles" for 4500N). Other than risks inherent in transport of liquids (i.e. potential for spills) no specific vulnerabilities were identified.

\section{Facilities Included in the ORNL Liquid Generator List}

The ORNL Liquid Generator List maintained by Duratek was reviewed and sixteen facilities were identified. Upon further investigation it was determined that the facility listings for the "generators" were actually the facilities where the generators had their offices. In four facilities $(1059,2001,3037$, and 7957) no liquid waste was actually produced. The "generator's" office happened to be in these facilities, but their waste generation activity was conducted elsewhere.

\section{Facilities Connected to PW System as Indicated on Drawings}

Three drawings sets - Q3D-12791-2001, 3JE20015-E002, and Duratek atlas drawings were reviewed identifying 33 UT-Battelle-managed facilities with connection to the PWS. There was generally good agreement among the drawing sets on the facility connections identified.

\section{Facilities Connected to PW System as Indicated in the Sink and Drain Survey}

The ORNL sink and drain survey (SADS) was reviewed, identifying 38 facilities with over 2,150 sinks and drains discharging to the PWS. The basis for the difference in number of facilities identified in the SADS compared to the number identified in the drawing review was not determined during the review. The SADS printouts for most facilities were checked during the facility walkdowns.

Based on the SADS, a survey was conducted with Environmental Protection Offices (EPOs) of facilities connected to the PWS. The EPO's were asked to review and provide updates to the SADS, indicate if bottling or trucking is used to transfer liquids to the PWS, provide an estimate of the volume and contaminant loading of the liquids discharged, and a basis for the estimate. 
Review of the survey data indicates that quantitative process data - volumes and contaminant concentrations - are not available for many of the generators who discharge to the PW system. While generators can satisfy current WAC through training and "process knowledge" the lack of this information makes it impossible to demonstrate that UT-Battelle operations are not contributing to further release of contaminants to the ORNL subsurface. In addition, it is apparent from the survey that large quantities, in the range of 100 to $140 \mathrm{Mgy}$, of single-pass cooling water are discharged to the PW system from UT-Battelle facilities. Detecting the resulting low contaminant concentrations makes environmental monitoring much more difficult, and the increased water flow in potentially leaking pipes can contribute to the transport of subsurface contaminants.

\section{Other Priority 2 facility vulnerabilities identified}

- PCB paint flaking has been occurring at 2000/2001 for several years. Actions have been undertaken to clean adjacent storm catchments and drains to control paint chip migration while the transition of the facility to the DOE EM Program is arranged. A potential regulatory vulnerability exists if this facility transfer is not executed.

- An unlabeled lunchroom sink drain was noted in $\mathbf{2 5 0 0}$ that was indicated on the Sink and Drain Survey as "process." The drain was immediately labeled.

- A residue was noted on the floor of the chemical storage room in $\mathbf{2 5 4 7}$ around an apparently empty 55-gal drum with corrosion noted at the bottom. The material was immediately cleaned up and the drum overpacked.

- Drains labeled "process" were noted in $\mathbf{3 5 0 2}$ that were indicated as "sanitary" in the Sink and Drain Survey. The drains were confirmed to be "sanitary" and relabeled immediately

- A hood in $\mathbf{3 5 0 2}$ containing chemicals used to support manipulator boot manufacture had recently had vent modifications performed that were identified as potentially not in compliance with air permit requirements. It was confirmed with Environmental Compliance and Waste Services staff that the hood operation and vent were compliant.

- Several questions on sinks and drains in $\mathbf{3 5 8 7}$ were noted and forwarded to facility management for resolution.

- A large mercury spill in the $\mathbf{4 5 0 1}$ basement during the 1950s leaked through cracks in the floor and into drains (that have since been sealed) and accumulated under the building and is presumably contributing to the known mercury leaks from this area to the storm drain system.

\subsubsection{Other Facilities and Vulnerabilities}

A number of additional vulnerabilities were identified during Priority 1 facilities, Priority 2 facilities, and other area walkdowns and through discussions with ORNL staff including the following:

- Historic airborne releases from off-normal operations in the 1950s in Bethel Valley have resulted in localized radioactive contamination on building roofs, such as the cafeteria.

- Historic airborne releases in Melton Valley, hypothesized to result from "dump and roll" waste disposal practices, have resulted in localized contamination in reservation areas maintained by UT-Battelle.

- A damaged plastic liner is evident on the bank of the western sewage lagoon. While not a regulatory violation, failure to repair the liner is not a best management practice.

- Continued discharge of mercury to the storm water system from 4500S and 3074 was noted.

- Deteriorated beryllium-contaminated ductwork was identified at 3044

- The availability and restrictions on the use of "capital" funds encourages the continued "management" of environmental vulnerabilities, such as use of single pass cooling, through use of overhead expense funding that may be more expensive in the long term. 
- ORNL does not currently have adequate capability to cleanup more than two workers who might become contaminated due to a spill. Up to two workers could be decontaminated at the Health Division but this operation could result in the contamination of currently clean areas.

- Several hot cell facilities have windows containing zinc bromide that have not been replaced. These types of windows have historically been prone to leaks due to the corrosive nature of the zinc bromide.

- A number of ORNL facilities rely on the Central Off Gas system operated by BJC to maintain negative pressure in contaminated areas. While there have not historically been problems with maintaining the system negative pressure, there have been instances where localized loss of negative pressure has been experienced.

A review of environmental vulnerabilities was performed as part of this assessment by a group of retired employees familiar with ORNL history and operations and the results of this review have been placed in the FEVA file. Several of the incidents noted were also identified by current facility management and are reflected in this text. However, the assessment team was not able to verify the current condition of a number of the vulnerabilities noted, and these should be explored further during follow-on activities.

\subsection{Are Any UT-Battelle Facilities Discharging Significant Amounts of Contaminants to the Environment?}

UT-Battelle management requested that this assessment answer the question, "Are any UT-Battelle facilities discharging significant amounts of contaminants to the environment?" The FEVA assessment team has concluded that the potential exists that other UT-Battelle-managed operating facilities at ORNL are releasing low levels of contaminants to the environment through connections to the process waste system. Any such release is below regulatory limits and is not currently being detected. This conclusion is based on the following conditions noted during FEVA.

- HFIR is the only Category 1 facility at ORNL. No other routine operations were identified with the potential source term release similar to HFIR. Most of the operations conducted at ORNL are smaller scale cell- or bench-top operations with limited process material volumes and discharges under normal operations.

- ORNL environmental monitoring program results do not indicate that any contaminant releases are occurring that are above regulatory limits.

- Programs are not in place to confirm the integrity of the connections from UT-Battelle facilities to the PW system.

- The large amount of once-though cooling water introduced to the PW system from UTBattelle operations reduces the concentration of contaminants that might leak from the PW system.

- The current ORNL Environmental Monitoring Program would not likely be able to differentiate low concentration releases from UT-Battelle operations from those associated with the presence of legacy contamination at ORNL.

- The FEVA concluded that there is good confidence that BJC PW system monitoring and ORNL environmental monitoring are in place and could detect "high" concentration releases although these programs may not be able to differentiate them from legacy-related releases. While current barriers would be capable of controlling or reducing major operational upsets, catastrophic events (wind, seismic, fire) could result in significant environmental releases. 
The assessment team concluded that despite the identification of deteriorated contaminated ventilation ducts and vents, the potential for releases of airborne contamination from these systems was low due to the negative pressure maintained by the central off gas system. It was noted that there is a potential for leakage of liquids from the vent system low points. 



\subsection{Conclusions}

\subsection{Overview}

From mid-April through the end of June 2001, a Facility Environmental Vulnerability Assessment (FEVA) was performed at Oak Ridge National Laboratory (ORNL). The primary goal of this FEVA was to establish an environmental vulnerability baseline at ORNL that could be used to support the Laboratory planning process and place environmental vulnerabilities in perspective. The information developed during the FEVA was intended to provide the basis for management to initiate immediate, near-term, and long-term actions to respond to the identified vulnerabilities. It was expected that further evaluation of the vulnerabilities identified during the FEVA could be carried out to support a more quantitative characterization of the sources, evaluation of contaminant pathways, and definition of risks. The FEVA was modeled after the Battelle-supported response to the problems identified at the High Flux Beam Reactor at Brookhaven National Laboratory. This FEVA report satisfies Corrective Action 3A1 contained in the Corrective Action Plan in Response to Independent Review of the High Flux Isotope Reactor Tritium Leak at the Oak Ridge National Laboratory, submitted to the Department of Energy (DOE) ORNL Site Office Manager on April 16, 2001.

This assessment successfully achieved its primary goal as defined by Laboratory management. The assessment team was able to develop information about sources and pathway analyses although the following factors impacted the team's ability to provide additional quantitative information:

- the complexity and scope of the facilities, infrastructure, and programs;

- the significantly degraded physical condition of the facilities and infrastructure;

- the large number of known environmental vulnerabilities;

- the scope of legacy contamination issues (not currently addressed in the EM Program);

- the lack of facility process and environmental pathway analysis performed by the accountable line management or facility owner; and

- poor facility and infrastructure drawings.

The assessment team believes that the information, experience, and insight gained through FEVA will help in the planning and prioritization of ongoing efforts to resolve environmental vulnerabilities at UTBattelle-managed ORNL facilities.

A summary table of the vulnerabilities and observations developed during FEVA is provided in Exhibit 3.

\subsection{Immediate Issues}

The FEVA did not identify any major vulnerabilities associated with the UT-Battelle-managed facilities that warranted immediate "stop work" or "initiate immediate response" actions. The assessment team evaluated 11 Priority 1 facilities that contain significant hazardous material inventories and typically conduct hot cell or glove box type operations that use relatively small quantities (on the order of grams to kilograms) of materials. The team also evaluated 64 Priority 2 facilities with smaller inventories of hazardous materials. No situations were identified where significant release of contaminants to the environment was occurring or where an imminent threat of a release existed. The FEVA did determine that significant environmental impacts could be associated with off-normal conditions such as inadvertent sprinkler discharge, fire, high winds, or seismic events. These lower probability events are evaluated as 
part of facility safety authorization basis, and environmental vulnerabilities are typically mitigated by a combination of safety and defense-in-depth systems.

Guidance will be issued to Laboratory management and staff to include the resources (funding and staff) in the FY 2002 budget, which is currently being prepared, to support the actions needed to prioritize, plan, and implement responses to the recommendations contained in this report.

\subsection{Scope of Vulnerabilities}

Most of the environmental vulnerabilities that FEVA identified were well known by facility managers and staff and in many cases had been long standing issues. Local actions had been taken over the years to partially mitigate many of these by temporarily containing the sources and instituting a surveillance program to detect potential leakage. The vulnerabilities span the UT-Battelle facilities that are identified as surplus, scheduled for disposition, or are strategic facilities. Vulnerable areas include both facilities and the supporting infrastructure, presenting a formidable task for management to integrate and prioritize the resolution of identified issues. Vulnerabilities were also identified with the significant amount of surface and below-grade legacy contamination that is present at the ORNL site.

The current environmental policy and planning process should be capable of evaluating and prioritizing the actions needed to resolve the vulnerabilities identified; however, the baseline information that identifies vulnerabilities and that drives the decision process is not available in a form that assists senior management in this process. For a number of reasons that are outlined in the report, the majority of the vulnerabilities were not elevated to the senior management, were not funded, or stopped being sent forward. The lack of clearly defined ownership for infrastructure, the lack of specific facility process and pathway analysis, the lack of an integrated multimedia environmental protection strategy and plan, and the past reactive minimal compliance policies contributed to this significant deficiency.

\subsection{Control and Detection of Significant Releases}

Progress has been made at ORNL in reducing the overall scope of environmental vulnerabilities, and current initiatives will reduce them further. Many of the most significant legacy sources have been contained or removed, and the DOE EM Program will continue to reduce the source term through a prioritized and risk-based methodology. Overall, ORNL is controlling and would be able to detect large acute, chronic, or intermittent releases of contaminants to the environment. The integrity of the sink and drain study and the environmental monitoring program results add confidence that significant releases are controlled and that new releases would be identified.

\subsection{Control and Detection of Chronic Small Releases}

While UT-Battelle is able, with a good degree of assurance, to validate that there are no acute, largevolume, or intermittent releases from its facilities, the same assurance cannot be provided with respect to chronic or infrequent low-volume, low-concentration releases. This situation is due to significant masking from a deteriorated infrastructure (e.g., potable water, storm water, process waste, sanitary sewer), the large amount of legacy contamination at the ORNL site, and volumetric dilution due to the use of large quantities of single-pass cooling water. Low-volume or low-concentration sources cannot be detected at present because of this masking. Reduction in the volume of single-pass cooling water discharged to drain systems will enhance the capability to detect smaller releases and locate smaller leaks between facility 
and manhole. This volume reduction effort, however, may have the undesirable side effect of increasing concentrations at the treatment facility acceptance points in the storm water, sanitary sewer, and process waste system outfalls, which could negatively impact the ability to meet the current National Pollutant Discharge Elimination System (NPDES) permit limits. 



\subsection{Recommended Actions}

\subsection{Recommendations}

As indicated in High Flux Isotope Reactor (HFIR) Corrective Action 3A1, the development and prioritization of long-term corrective actions for ORNL facilities will be accomplished through the deployment of the Standards Based Management System (SBMS) and by the new Facilities and Operations Model. The assessment team has developed the following recommendations for consideration during this process.

\subsection{Near-Term Actions: 2 Years or Less to Implement}

- Develop and communicate UT-Battelle environmental expectations and policy to staff and stakeholders - in process

- Complete excess chemical inventory reduction initiative - in process

- Complete legacy waste identification and clean out - in process

- Complete funded infrastructure upgrades-in process

- Support continued funding of and integration with DOE EM Program activities at ORNL - in process

- Evaluate and pilot elimination of contaminant discharges to process waste system

- Determine return on investment (ROI) benefit and regulatory impacts associated with minimizing single-pass cooling water

- Determine destination of discharges from vacuum system moisture traps

- Review vulnerabilities noted by retired employees and reconcile with current conditions

- Conduct facility process evaluations as part of the Facility Operations and Maintenance Management System - in process

- Develop the Environmental Management System with emphasis on pollution prevention and waste minimization to prioritize strategic investments to meet management expectations - in process

\subsection{Long-Term Actions: 2-10 Years to Implement}

- Support continued funding of and integration with DOE EM Program activities at ORNL

- Develop and implement Strategic Facilities Upgrade Plan (subsurface)

- Implement recently updated Pollution Prevention Program, which calls for an integrated multimedia environmental risk analysis process

- Complete facilities infrastructure upgrades (e.g., drinking water, sanitary sewer, storm sewer, off-gas, and vent systems)

- Minimize the use of potable water for single-pass cooling water

- Develop "zero discharge" operations except in key and limited areas, determined through an exclusion process

- Consolidate operations to the main ORNL site (vacate Y-12 National Security Complex) and transition facilities to the EM Program. 



\subsection{Selected Bibliography}

Murphy, J. B. Groundwater Protection Program Management Plan. September 1998. Under revision at Oak Ridge National Laboratory.

National Pollutant Discharge Elimination Systems. National Pollutant Discharge Elimination System Permit No. TN0002941 Chlorine Control Strategy. Updated July 1, 2000.

Oak Ridge National Laboratory. Aging Equipment Assessment for Oak Ridge National Laboratory (ORNL) Nuclear Facilities. November 2000.

Oak Ridge National Laboratory. ORNL Hot Cell Facilities Assessment Team Report. April 11, 2001.

Oak Ridge National Laboratory. "Laboratory Strategic Plan," Institutional Plan, FY 2001-FY 2005, ORNL/PPA-2000/2. November 2000. ORNL Intranet URL:

http://www.ornl.gov/inst plan/StratPlan.html.

Oak Ridge National Laboratory. "Sink and Drain Manager." May 21, 2001. ORNL Intranet URL: http://oecdwsrv.oecd.ornl.gov/water/sinkanddrainhome.htm.

Oak Ridge National Laboratory. Comprehensive Storm Drain Survey at the Oak Ridge National Laboratory. September 1997.

Oak Ridge National Laboratory. Corrective Action Plan in Response to Independent Review of the High Flux Isotope Reactor (HFIR) Tritium Leak at the Oak Ridge National Laboratory. April 16, 2001.

Oak Ridge National Laboratory. Institutional Plan, FY 2001-FY 2005. ORNL/PPA-2000/2. November 2000. ORNL Intranet URL: http://www.ornl.gov/inst_plan/IP_outline.html.

Oak Ridge National Laboratory. Land and Facilities Plan. ORNL/TM-2000/237. December 2000. ORNL Intranet URL: http://www.ornl.gov/ dmsi/landUse/plan.html.

Oak Ridge National Laboratory. Oak Ridge National Laboratory Facilities Revitalization Project Management Plan. ORNL/TM-2000/174. July 2000.

Oak Ridge National Laboratory. ORNL Compliance with the Clean Air Act, ORNL-EP-P02, Rev. 2, Nov. 10, 1998. ORNL Intranet URL:

http://eshtrain.ct.ornl.gov/SBMS/SBMSearch/ORNLProc/ep02a.htm.

Oak Ridge National Laboratory. SBMS Management System Description: "Emergency Management." May 21, 2001. ORNL Intranet URL: http://eshtrain.ct.ornl.gov/sbms/SBMSearch/MSD/EPS/EPS_MSD. 
Oak Ridge National Laboratory. SBMS Management System Description: "Environmental Management." March 26, 2001. ORNL Intranet URL:

http://eshtrain.ct.ornl.gov/SBMS/SBMSearch/MSD/EMS/EMS_MSD.cfm.

Oak Ridge National Laboratory. SBMS Management System: "Performance Based Management." March 3, 2001. ORNL Intranet URL: http://eshtrain.ct.ornl.gov/SBMS/SBMSearch/MSD/PBM/PBM MSD.cfm.

Oak Ridge National Laboratory. SBMS Management System: Environmental Management, "Program Description: Pollution Prevention." April 5, 2001. ORNL Intranet URL: http://eshtrain.ct.ornl.gov/SBMSearch/ProgDesc/ORNL-WM-004.cfm.

Oak Ridge National Laboratory. SBMS Management System: Environmental Management, "Program Description: Spill Prevention, Control, and Countermeasures Compliance." ORNL ECS/93-10, Rev. 3, August 1998, ORNL Intranet URL:

http://oecdwsrv.oecd.ornl.gov/water/spcc/spcctoc.htm.

Oak Ridge National Laboratory. SBMS Management System: Training and Qualification, Program Description: “Training Program.” February 28, 2001. ORNL Intranet URL: http://eshtrain.ct.ornl.gov/SBMS/SBMSearch/MSD/TQ/TQ_MSD.cfm.

Oak Ridge National Laboratory. SBMS Management System: Worker Safety and Health, Program Description: "Chemical Safety Management." February 19, 2001. ORNL Intranet URL: http://eshtrain.ct.ornl.gov/sbms/SBMSearch/ProgDesc/ORNL-SH-040.cfm.

Oak Ridge National Laboratory. SBMS Management System: Worker Safety and Health, Program Description: "Integrated Safety Management System (ISMS)." April 17, 2001. ORNL Intranet URL:http://eshtrain.ct.ornl.gov/SBMS/SBMSearch/ProgDesc/lm003.cfm.

Oak Ridge National Laboratory. SBMS ORNL Work Smart Standards, March 21, 2001.

Oak Ridge National Laboratory. Sink and Drain Database. May 3, 2001. ORNL Intranet URL: http://oecdwsrv.oecd.ornl.gov/water/sinkanddrainhome.htm.

Oak Ridge National Laboratory. Storm Water Pollution Prevention Plan. Rev. 3, August 8, 2001. ORNL Intranet URL:

http://oecdwsv.oecd.ornl.gov/water/swp3/swp3document/swp3toc.htm.

Oak Ridge National Laboratory. Strategic Facilities Plan. ORNL/TM-2000/238. October 2000. ORNL Intranet URL: http://www.ornl.gov/ dmsi/strategic_plan/index.html.

Smith, J. G. et al. Biological Monitoring and Abatement Program. March 22, 2000.

Tennessee Department of Environment and Conservation, Division of Water Pollution Control. NPDES Permit No. TN0002941. December 6, 1996. 


\section{Exhibit 1 - Instructions and Checklists}

\section{INSTRUCTIONS}

\section{Overview}

The purpose of this facility review is to assess and document conditions contributing to radiological and chemical vulnerabilities and legacies. The assessment will include a review of the radiological and chemical material inventory, and the administrative and engineered controls that are in place for containment and regulatory compliant safe storage of the material.

Specific assessments to be completed during the review include risk from the material, the effectiveness of the controls preventing release, potential for unmonitored release of material to the environment or exposure to staff, and regulatory compliance. An assessment for legacy conditions that are documented in FIMS data fields will also be conducted.

To assure that an objective, thorough, and consistent review is done on the various sites and facilities, the review and assessment will be conducted using a checklist containing specific questions. The review is not intended to cover $100 \%$ of all potential vulnerabilities. If vulnerabilities are mitigated by administrative controls, a spot check of the effectiveness of the administrative controls will verify the adequacy of the control for each facility. Proprietary and classified information will be reviewed by appropriate individuals, remaining in compliance with business and security standards.

The review will be documented and archived, to provide information for future risk evaluation and facility transition. The intent is to document sufficient information so an in depth evaluation of hazards can be performed, and to identify legacies that exist in PNNL facilities. To accomplish this end, it is critical that all information reviewed and steps taken are documented.

\section{Review Process Steps}

1. Define \& assign team members based on subject area expertise (air, water, waste, safety, chemicals, etc.) Team size may vary depending on building and issues. Pick one person as lead coordinator and communicator for that building review.

2. Evaluate the "Resource" list (documented below) and assign items to team members based on expertise.

3. Individuals begin 1-5 day independent "homework" by reviewing all on-file data regarding the facility and their area of concern. (Gather facts, identify contacts, list questions, prioritize concerns, review prints, i.e., become as knowledgeable as possible on building history based on current known files.)

4. Glean and highlight the information from existing general documents. Where possible, pull out building specific data that can be collected and assembled in one file unique to that building.

5. Set up a "War Room" where prints, photos and files can be layed out, and information kept in front of all team members.

6. Meet as a group to share information, combine "to do" lists, identify gaps, and create the strategy for a path forward (tour, more review, interviews, specific actions to be completed or NA'ed on checklist.)

7. Identify the key building contact(s) needed to lead a tour (Building Manager, FSR, ECR or combination-be advised as to entry or training needs). 
8. Set up a tour with minimum team members to: 1 ) interview facility staff (use standard form to document interview info), and 2) tour the building taking photos or whatever needed to document issues and vulnerabilities. Notify appropriate individuals immediately if regulatory compliance or significant operational problems are found.

9. Individually evaluate data (make record copies) and tour information and then meet collectively to compile and come to closure and list conclusions.

10. Assign one person to compile the data and complete the report. The report will consist of 1) the completed review sheet, 2) an attachment organized by item number for extensive comments and detailed explanations, and 3) a sheet for each member detailing chronologically what activities were performed during the review including interviews, who with, what information reviewed, walkdowns performed, etc. Make the report as concise as possible, points are not given for volume!

11. Put together draft report and route to team members for review.

12. Finalize report and distribute.

Do's

- Share info - be a resource.

- Communicate with team members.

- Be specific.

$\underline{\text { Don'ts }}$

- Work in a vacuum.

- Descend on a building as individuals.

- Assume others know what you are doing.

Not all of the review questions apply to all facilities and sites. Check NA for all that are Not Applicable. Explain basis for the NA if it is not obvious.

Cleaning supplies in normal quantities used for cleaning the facility shall be excluded from this review. Stored quantities of cleaning supplies, such as 20 gallons of bleach, will not be excluded.

\section{Resource List}

To assure that the most efficient review is done, the material that would assist with completion of the review was identified, and obtained where appropriate. The material designated as being in the files, is physically located in file cabinets in 337 Building near room 2213.

\begin{tabular}{|l|l|}
\hline Resource & Source, Location \\
\hline 1. ONO Reports & $\begin{array}{l}\text { Obtained from Roger Pollari - in Legacy Waste } \\
\text { files 337/2213 }\end{array}$ \\
\hline 2. 2400 Phone Log Information & $\begin{array}{l}\text { Obtained from Security Control Room - in LW } \\
\text { fines 337/2213 }\end{array}$ \\
\hline 3. Radiation Protection Reports & $\begin{array}{l}\text { Obtained from Joe Jacobsen - in LW files } \\
337 / 2213\end{array}$ \\
\hline 4. WIDS List & $\begin{array}{l}\text { Obtained from John Bumgardner - in LW files } \\
337 / 2213-\text { maintained by Bechtel on internet } \\
\text { w/password }\end{array}$ \\
\hline
\end{tabular}




\begin{tabular}{|c|c|}
\hline 5. CATS & Contact Dee Barnett on 376-1328 \\
\hline 6. ES\&H Audits/Assessments & $\begin{array}{l}\text { Open items are in CATS - Contact Dee Barnett on } \\
376-1328\end{array}$ \\
\hline 7. Tiger Team Files & $\begin{array}{l}\text { Open items are in CATS - Contact Dee Barnett on } \\
376-1328\end{array}$ \\
\hline 8. "Open" Work Request & Contact Jan Bright on 376-9157 \\
\hline 9. PM Outstanding Waiver Report & $\begin{array}{l}\text { Obtained from Gary Fisher - in "Misc Book" on } \\
\text { LW files }\end{array}$ \\
\hline 10. Facilities Catalog PNL-MA-587 & In book case in Jan Bright's office 337/2223 \\
\hline 11. Facilities Data Sheets & In book case in Jan Bright's office 337/2223 \\
\hline 12. Septic Tank Systems List - Report \& Data & $\begin{array}{l}\text { Obtained from Jan Bright - in book on top of LW } \\
\text { files } 337 / 2213\end{array}$ \\
\hline 13. Tank Inventory for Selected PNNL Facilities & $\begin{array}{l}\text { Obtained from John Bumgardner - in book on top } \\
\text { of LW files }\end{array}$ \\
\hline 14. Liquid Waste Certification Plan for PNNL & $\begin{array}{l}\text { Obtained from Marvin McCarthy - in book on top } \\
\text { of LW files }\end{array}$ \\
\hline $\begin{array}{l}\text { 15. } 300 \text { Area Revitalization Project and WHC-MR- } \\
0925\end{array}$ & $\begin{array}{l}\text { Obtained from John Bumgardner - in "Misc Book" } \\
\text { on top of LW files }\end{array}$ \\
\hline 16. 300 Area Characterization Study & WHC-MR-0388 - in LW files 337/2213 \\
\hline 17. Criticality Material Facilities & Obtained from Mike Dec - in LW files 337/2213 \\
\hline 18. Condition Asset Survey & Contact Dave Harvey on 373-2945 \\
\hline 19. Historic Property Inventory Form & Contact Dave Harvey on 373-2945 \\
\hline 20.300 Area Strategy Review & Contact Bill Bjorklund on 376-4781 \\
\hline $\begin{array}{l}\text { 21. Manhattan Project Building (A construction } \\
\text { history) } \\
\text { WHC-MR- } 0425\end{array}$ & Contact Bill Bjorklund on 376-4781 \\
\hline 22. MBAs & $\begin{array}{l}\text { Obtained from Glenda Ackerman - in "Misc } \\
\text { Book" on LW files }\end{array}$ \\
\hline 23. Dye Test Data & $\begin{array}{l}\text { Obtained from Marvin McCarthy - in book on top } \\
\text { LW files }\end{array}$ \\
\hline 24. Variance (Waiver) Database & $\begin{array}{l}\text { Obtained from Glenn Hoenes - in "Misc Book" on } \\
\text { top LW files }\end{array}$ \\
\hline 25. F\&O Self-Assessment & $\begin{array}{l}\text { Obtained from Gordon Beeman - in "Misc Book" } \\
\text { on top LW files }\end{array}$ \\
\hline 26. PNNL Regulated Waste Inventory & $\begin{array}{l}\text { Obtained from Bruce Killand - in "Misc Book" on } \\
\text { top LW files }\end{array}$ \\
\hline $\begin{array}{l}\text { 27. PNNL Air Operating \& Notice of Construction } \\
\text { Action/Tracking Plan }\end{array}$ & $\begin{array}{l}\text { Obtained from Roger Woodruff - in "Misc Book" } \\
\text { on top LW files }\end{array}$ \\
\hline 28. Facility Use Agreements (FUA) & $\begin{array}{l}\text { On Internal Web - go to SBMS, toward bottom of } \\
\text { block on right side of page, click on smaller block } \\
\text { titled "Facility Use Agreements". Log on block } \\
\text { will appear. Log on and FUAs will appear }\end{array}$ \\
\hline $\begin{array}{l}\text { 29. Prints of Liquid and Air discharge - includes } \\
\text { FEMP drawings }\end{array}$ & $\begin{array}{l}\text { Obtained from PNNL Engineering Drawing Center } \\
\text { - in LW files }\end{array}$ \\
\hline
\end{tabular}




\begin{tabular}{|l|l|}
\hline $\begin{array}{l}\text { 30. Characterization and Monitoring of 300 Area } \\
\text { Facility Liquid Waste Streams During 1994 and } \\
\text { 1995 }\end{array}$ & $\begin{array}{l}\text { Obtained from Steve Jette - in book on top of LW } \\
\text { files }\end{array}$ \\
\hline 31. 1988-1995 EC Inspections Reports & $\begin{array}{l}\text { Contact Gary McNair - located in Joise } \\
\text { Gonzalez's office 337/3256 filed by building and } \\
\text { year }\end{array}$ \\
\hline 32. SAR \& Facility Designations & $\begin{array}{l}\text { Obtained from Tonia Graham - in "Misc Book" on } \\
\text { LW files }\end{array}$ \\
\hline 33. Satellite Accumulation Area Inventory & $\begin{array}{l}\text { Obtained from Amy Embree - in "Misc Book" on } \\
\text { top LW files }\end{array}$ \\
\hline 34. PNNL 90-Day Accumulation Areas & $\begin{array}{l}\text { Obtained from Ryan Lokken - in "Misc Book" on } \\
\text { top LW files }\end{array}$ \\
\hline 35. Lysimeter Sites & $\begin{array}{l}\text { Obtained from Bill Bjorklund - in "Misc Book" on } \\
\text { top LW files }\end{array}$ \\
\hline 36. 300 Area Vulnerability Reports & Obtained from Stan Jones - in Building LW files \\
\hline $\begin{array}{l}\text { 37. Environmental Assessments of 300 Area } \\
\text { Transition Facilities (SAIC Report) }\end{array}$ & Obtained from Stan Jones - in Building LW files \\
\hline $\begin{array}{l}\text { 38. Environmental RL \& Ecology Inspection } \\
\text { Information }\end{array}$ & Contact Harold Tilden - located in Harold's files \\
\hline 39. Hanford Site Asbestos Abatement Plan & Obtained from Jan Bright - in book on tip LW files \\
\hline 40. Asbestos Location Abatement Report & $\begin{array}{l}\text { Obtained from Larry Richards - in books on top } \\
\text { LW files }\end{array}$ \\
\hline 41. NEPA Files & Contact Regan Weeks on 376-8726 \\
\hline 42. Nuclear Hazard Cat of PNNL Facilities & Contact Tonia Graham or Mike Dec \\
\hline
\end{tabular}




\section{Vulnerability and Legacy Report}

\begin{tabular}{|l|l|l|}
\hline Facility/Site Number: & Review Completion Date: & Re \\
\hline Facility/Site Name: & \\
\hline Team Composition \\
\hline Lead: \\
\hline Member: \\
\hline Member: \\
\hline Member: \\
\hline $\begin{array}{l}\text { Facility/Site Description, Missions, and History } \\
\text { Describe the facility/site, and as much of the facility history as can be retrieved as is determined appropriate by the } \\
\text { assessment leader. Use the Past Practices Technical Characterization Study - 300 Area as a guideline for format. }\end{array}$
\end{tabular}

\section{Facility Current Status}

Describe the facility operational status. If the facility is in standby or not occupied, describe the status in detail.

_ Facility Operating

- Facility Shutdown

- Ventilation shut down

- Ventilation capped

Water Systems isolated and facility freeze protected

_ Electricity disconnected to facility

\section{Facility/Site Summary of Vulnerabilities and Legacies}

Summarize the results of the review that was performed. Address the following as a minimum:

- Are there any unmanaged, inappropriately managed, or unassessed radiological, chemical, or regulatory vulnerabilities?

- Describe all vulnerabilities and legacies. For each legacy or concern identified, provide as much information as possible, such as specific contaminants, specific locations, how the material came to be there, knowledgeable personnel, etc. (Summarize the team members inputs here.)

\section{Critique}

Summarize the facility/site and the review, addressing the following as appropriate:

- Where are improvements or changes required or recommended?

- What are the positive features about the hazard management activities associated with this building?

- Was an effective review done? What additional should be done?

- Where have actions been assigned? 


\section{Characterization Adequacy and Hazards Screening Section}

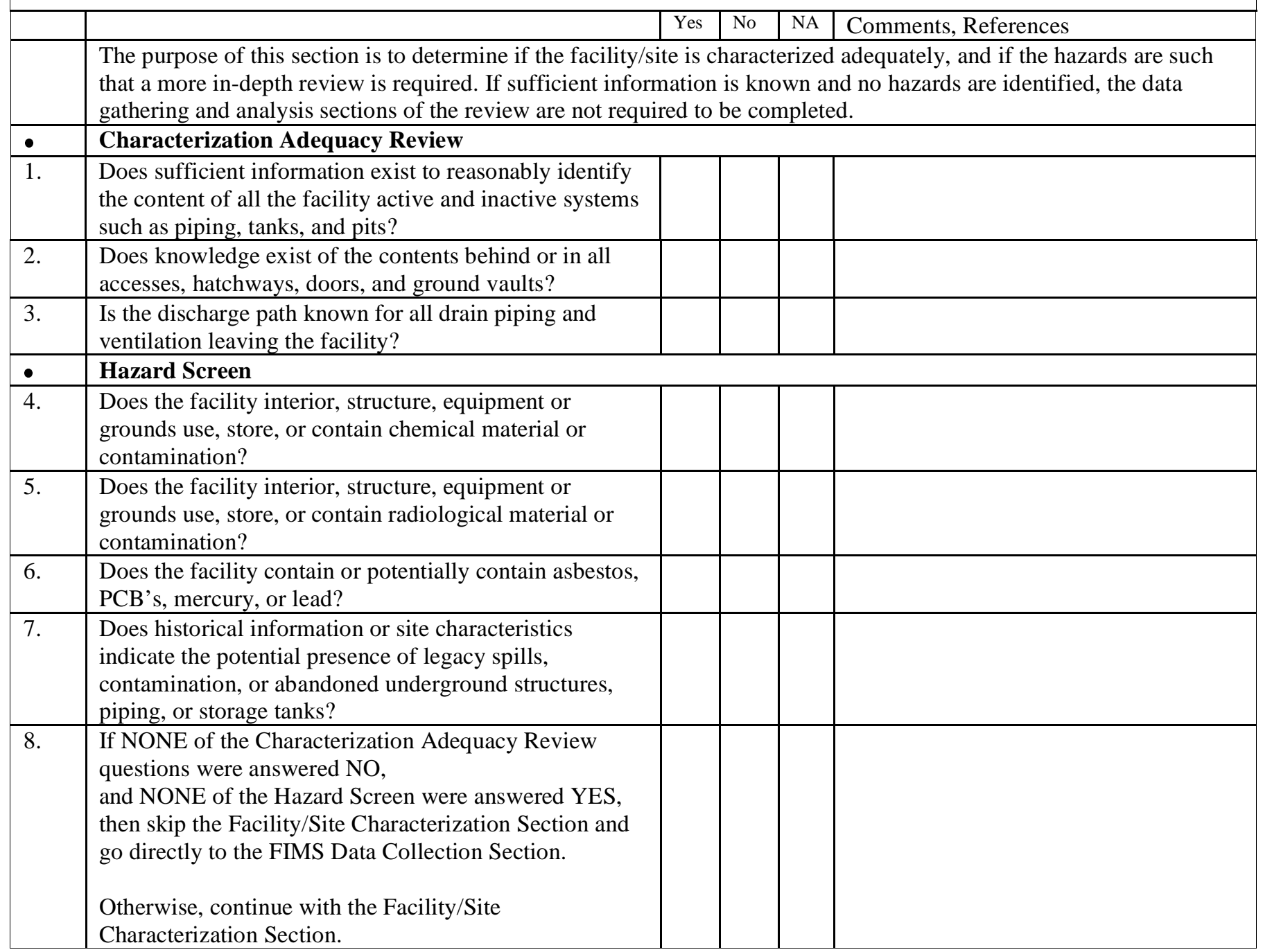




\section{Facility/ Site Characterization Section}

\begin{tabular}{|c|c|}
\hline • & $\begin{array}{l}\text { Specific Chemical/Radiological Material Review } \\
\text { Some materials/situations require special attention in the assessment of vulnerabilities. For each of the following, } \\
\text { indicate if the material/situation exists, and if so indicate location, quantity and any other known information in the } \\
\text { comments. }\end{array}$ \\
\hline 1. & $\begin{array}{l}\text { Waste Contained in Facility } \\
\text { — LLW } \quad-\text { RMW } \quad-\text { TRU _ Hazardous _ _ Solid non reg. _ Other }\end{array}$ \\
\hline 2. & $\begin{array}{l}\text { PCBs } \\
\text { - Transformers } \quad \text { Ballasts } \quad \text { Other }\end{array}$ \\
\hline 3. & $\begin{array}{l}\text { Lead } \\
- \text { Shielding } \quad \text { Paint } \quad \text { Other }\end{array}$ \\
\hline 4. & $\begin{array}{l}\text { Mercury } \\
\text { - Switches _ } \quad \text { Thermostats } \quad \text { O Other }\end{array}$ \\
\hline 5. & $\begin{array}{l}\text { Glycol's } \\
\text { _ Ethylene } \quad \text { Propylene } \quad \text { - Other }\end{array}$ \\
\hline 6. & $\begin{array}{l}\text { Other significant material } \\
\begin{array}{l}\text { Carcinogen } \\
\text { Potentially lethal }\end{array}-\text { Other }\end{array}$ \\
\hline$\bullet$ & $\begin{array}{l}\text { Facility/Site Structure Review } \\
\text { For each of the following, specify what currently exists or PREVIOUSLY existed in the facility. Provide as much } \\
\text { information as possible on areas with contamination of any type, such as specific location and chemicals, metals, or } \\
\text { isotopes involved. }\end{array}$ \\
\hline 7. & $\begin{array}{l}\text { Asbestos: } \\
\text { Tile } \quad \text { Insulation } \quad \text { - Transite } \quad \text { - Other }\end{array}$ \\
\hline 8. & $\begin{array}{l}\text { Evidence of spills or discharges: } \\
\text { _ Stains _ Postings _ WIDS documentation _ _ _ Other }\end{array}$ \\
\hline 9. & $\begin{array}{l}\text { Historical use of material with potential for contamination of facility/site: } \\
\text { _ Radiological contamination } \quad-\text { Beryllium } \quad \text { - Chemical } \quad-\text { Other }\end{array}$ \\
\hline 10. & $\begin{array}{l}\text { Storage areas with potential for chemical or radiological vulnerabilities: } \\
\text { Chemical storage } \quad \text { Waste storage } \quad \text { Janitorial storage } \\
\text { Drum storage } \quad \text { Other }\end{array}$ \\
\hline 11. & $\begin{array}{l}\text { Roof and Exterior Condition: } \\
\text { _ All exterior openings sealed }\end{array}$ \\
\hline
\end{tabular}




\begin{tabular}{|c|c|}
\hline • & $\begin{array}{l}\text { Facility/Site System Review } \\
\text { For each of the following, check each that exists. Provide a status on whether it is active or inactive and a status which } \\
\text { includes: a) if the structure, system, or component contains or is contaminated with material, b) the nature of the } \\
\text { material c) associated radiological and chemical vulnerabilities, and d) status of characterization. Refer to prints, } \\
\text { studies, etc. when the data exists. }\end{array}$ \\
\hline 12. & $\begin{array}{l}\text { Piping Systems with potential for containing radiological or chemical contamination or material. } \\
\text { _ Abandoned lines } \\
\text { _ Process sewer_ RLWS Connections to other bldgs. or systems } \\
\text { _ }\end{array}$ \\
\hline 13. & 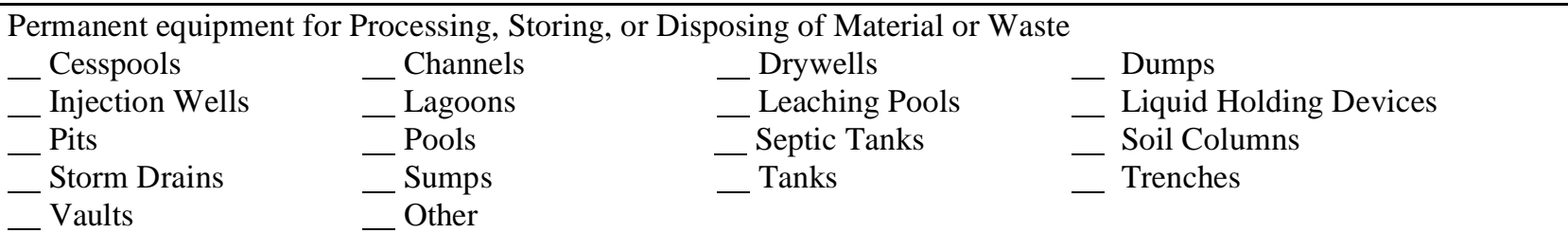 \\
\hline 14. & 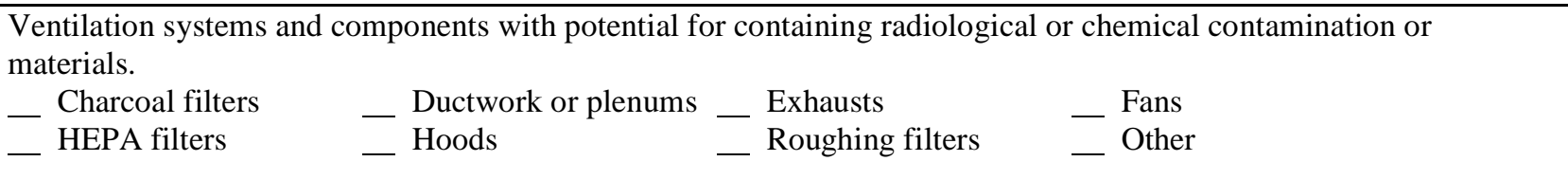 \\
\hline 15. & $\begin{array}{l}\text { Other facility equipment with a significant potential for contamination or potential to contribute to a spill or discharge. } \\
\text { Elevators } \\
\text { — Discharges, outfalls, or drains or not otherwise noted }\end{array}$ \\
\hline 16. & $\begin{array}{l}\text { Is the facility CMS inventory accurate (check at least one toxic or large inventory chemical)? } \\
\text { - Yes _ No }\end{array}$ \\
\hline 17. & $\begin{array}{l}\text { Is the facility part of the Hanford Historic District, contain Manhattan Project or Cold War artifacts, or subject to } \\
\text { cultural or sensitive environmental considerations? } \\
\text { - Yes _ No _ Unknown }\end{array}$ \\
\hline 18. & $\begin{array}{l}\text { Does the facility discharge any non-contact cooling water to a sanitary or process sewer? } \\
\text { _ Yes _ No }\end{array}$ \\
\hline
\end{tabular}




\begin{tabular}{|c|c|c|c|c|c|}
\hline \multicolumn{6}{|c|}{ Assessment and Analysis Section } \\
\hline & & Yes & No & NA & Comments, References \\
\hline - & \multicolumn{5}{|l|}{ Vulnerability Assessment } \\
\hline 1. & $\begin{array}{l}\text { Have the hazardous and radiological materials been } \\
\text { adequately inventoried and characterized to determine } \\
\text { their type, quantity and potential risks? Spot check the } \\
\text { inventory. }\end{array}$ & & & & \\
\hline 2. & Are MSDS's available for every chemical in inventory? & & & & \\
\hline 3. & $\begin{array}{l}\text { Are proper chemical and radiological storage practices } \\
\text { in place for all of the materials at this facility? }\end{array}$ & & & & \\
\hline 4. & $\begin{array}{l}\text { Are storage tanks in adequate material condition, } \\
\text { structurally sound, and properly vented? }\end{array}$ & & & & \\
\hline 5. & $\begin{array}{l}\text { Is the stored material chemically and radiologically } \\
\text { compatible with storage container materials? }\end{array}$ & & & & \\
\hline 6. & Chemical compatibility during storage checked? & & & & \\
\hline 7. & $\begin{array}{l}\text { Is there structural or mechanical deterioration of } \\
\text { facilities or equipment where chemical and radiological } \\
\text { materials are stored, handled or processed? }\end{array}$ & & & & \\
\hline 8. & $\begin{array}{l}\text { Are storage facilities adequate for the types and } \\
\text { quantities of materials stored in them? }\end{array}$ & & & & \\
\hline 9. & $\begin{array}{l}\text { Spot check required inspection records to assure the } \\
\text { inspections are being done. }\end{array}$ & & & & \\
\hline 10. & Are facility postings correct? & & & & \\
\hline$\cdot$ & Safety/Regulatory Envelope Assessment & & & & \\
\hline 11. & $\begin{array}{l}\text { Is the building/ facility Hazard Category designation } \\
\text { consistent with the current operations mode and material } \\
\text { contained in the facility? }\end{array}$ & & & & \\
\hline 12. & $\begin{array}{l}\text { Is the SAR (if applicable) and FUA appropriate for the } \\
\text { operations in the facility? }\end{array}$ & & & & \\
\hline 13. & $\begin{array}{l}\text { Is the configuration management process ensuring that } \\
\text { documents are revised to reflect changing facility } \\
\text { conditions? }\end{array}$ & & & & \\
\hline 14. & $\begin{array}{l}\text { Are specific permits applicable to this facility, such as } \\
\text { RCRA, air, water, NPDES, or TSCA? If so, are the } \\
\text { permit limits and requirements reflected in the facility } \\
\text { administrative controls? Spot check permit } \\
\text { requirements vs. administrative control, and } \\
\text { administrative control vs. field conditions. }\end{array}$ & & & & \\
\hline - & Emergency Response Assessment & & & & \\
\hline 15. & $\begin{array}{l}\text { Is the chemical and radiological inventory appropriately } \\
\text { addressed by the safety and emergency response } \\
\text { documentation? }\end{array}$ & & & & \\
\hline 16. & $\begin{array}{l}\text { Do the safety documents have any chemical and } \\
\text { radiological accident scenarios? }\end{array}$ & & & & \\
\hline 17. & $\begin{array}{l}\text { Are there any chemical or radiological accident "Action } \\
\text { Levels" established for this facility? }\end{array}$ & & & & \\
\hline 18. & $\begin{array}{l}\text { Are there any new hazardous materials that should be } \\
\text { identified to emergency responders? }\end{array}$ & & & & \\
\hline
\end{tabular}




\section{FIMS Data Collection Section}

This information is being used to complete data for the FIMS system. Complete this for all facilities reviewed. Contact for this section is Amie Lee.

\begin{tabular}{|c|c|c|c|c|}
\hline - & \multicolumn{4}{|c|}{ Chemical, Radiological, and Waste Inventory } \\
\hline 1. & PCB's & None & $<10 \mathrm{lbs}$ & $>=10 \mathrm{lbs}$ \\
\hline 2. & Friable Asbestos & None & $<10 \mathrm{lbs}$ & $>=10 \mathrm{lbs}$ \\
\hline 3. & Transite as Non Friable & None & $<10,000 \mathrm{sq} \mathrm{ft}$ & $>=10,000 \mathrm{sq} \mathrm{ft}$ \\
\hline 4. & Mercury & None & $<10 \mathrm{lbs}$ & $>=10 \mathrm{lbs}$ \\
\hline 5. & Explosives, TNT & None & $<100 \mathrm{lbs}$ & $>=100 \mathrm{lbs}$ \\
\hline 6. & Stored Flammable Liquids & None & $<1000$ gal & $>=1000 \mathrm{gal}$ \\
\hline 7. & Other Hazardous Materials & None & \multicolumn{2}{|c|}{ Listed in Comments } \\
\hline 8. & Transuranic Waste & None & $<1000 \mathrm{~cm}$ & $>=1000 \mathrm{~cm}$ \\
\hline 9. & Mixed TRU & None & $<1000 \mathrm{~cm}$ & $>=1000 \mathrm{~cm}$ \\
\hline 10. & High Level Waste (HLW) & None & $<1000 \mathrm{~cm}$ & $>=1000 \mathrm{~cm}$ \\
\hline 11. & Low Level Waste (LLW) & None & $<1000 \mathrm{~cm}$ & $>=1000 \mathrm{~cm}$ \\
\hline 12. & Mixed LLW & None & $<1000 \mathrm{~cm}$ & $>=1000 \mathrm{~cm}$ \\
\hline 13. & Spent Nuclear Fuel & None & $<100$ MTHM & $>=100 \mathrm{MTHM}$ \\
\hline 14. & Unirradiated Nuclear Fuel & None & $<100$ MTHM & $>=100 \mathrm{MTHM}$ \\
\hline 15. & Source Material & None & $<100 \mathrm{~kg}$ & $>=100 \mathrm{~kg}$ \\
\hline 16. & Radioactive Source/Other & None & $<100 \mathrm{~kg}$ & $>=100 \mathrm{~kg}$ \\
\hline 17. & Radioactive Material & None & $<50 \%$ & $>=50 \%$ \\
\hline$\cdot$ & \multicolumn{4}{|l|}{ Facility Hazard Category } \\
\hline 18. & \multicolumn{2}{|c|}{$\begin{array}{l}\text { Check the associated Hazard Category and Characteristics } \\
\text { of the facility. Use the "radiological" or "chemical" } \\
\text { questions above to determine if the facility has radiological } \\
\text { or chemical hazards as defined for FIMs. At this time the } \\
325 \text { Building is the only Nuclear Category facility in } \\
\text { PNNL, and is a Nuclear Category II. }\end{array}$} & \multicolumn{2}{|c|}{$\begin{array}{l}\text { Radiological Facility } \\
\text { _ Chemical Hazard Facility } \\
\text { _ Nuclear Category } 2 \text { and Chemical Hazard Facility } \\
\text { Radiological Facility and Chemical Hazard Facility } \\
\text { _ Not Applicable }\end{array}$} \\
\hline
\end{tabular}


Exhibit 2 - Interviews Conducted

\begin{tabular}{|c|c|c|c|c|c|c|}
\hline $\begin{array}{l}\text { FACILITY } \\
\text { MANAGER'S } \\
\text { NAME }\end{array}$ & $\begin{array}{l}\text { FACILITY } \\
\text { ID } \\
\text { NUMBER }\end{array}$ & FACILITY NAME & ORGANIZATION & $\begin{array}{l}\text { INTERVIEW } \\
\text { DATE }\end{array}$ & $\begin{array}{l}\text { INTERVIEW } \\
\text { LEAD(S) }\end{array}$ & FACILITY LEAD(S) \\
\hline Caquelin, D.A. & 2026 & $\begin{array}{l}\text { Radioactive Materials Analytical } \\
\text { Laboratory (RMAL) }\end{array}$ & $\begin{array}{l}\text { Chemical and Analytical } \\
\text { Sciences }\end{array}$ & $05 / 10 / 2001$ & $\begin{array}{l}\text { Carlo Melbihess } \\
\text { David Skipper }\end{array}$ & Dale Caquelin \\
\hline Patton, B.D. & $3019 A$ & $\begin{array}{l}\text { Radiochemical Development } \\
\text { Facility }\end{array}$ & Chemical Technology & $04 / 25-26 / 2001$ & $\begin{array}{l}\text { Bill Miller } \\
\text { Steve Handley }\end{array}$ & $\begin{array}{l}\text { Alan Krichinsky } \\
\text { Ray Bond }\end{array}$ \\
\hline Turner, L.J. & $3025 \mathrm{E}$ & IMET Facility (Hot Cells) & Metals \& Ceramics & $05 / 07 / 2001$ & Carlo Melbihess & Lloyd Turner \\
\hline Patton, B.D. & 3027 & Special Nuclear Materials Vault & Chemical Technology & $04 / 24 / 2001$ & $\begin{array}{l}\text { Dirk Van Hoesen } \\
\text { Hans Vogel }\end{array}$ & $\begin{array}{l}\text { A.Krichinsky/J.Rushton/ } \\
\text { R.Bond/B.Starns/ }\end{array}$ \\
\hline Patton, B.D. & 3047 & $\begin{array}{l}\text { Radioisotope Development } \\
\text { Laboratory }\end{array}$ & Chemical Technology & $04 / 24-26 / 2001$ & Dirk Van Hoesen & Herman Phillips \\
\hline DeVore, C.E. & 3525 & $\begin{array}{l}\text { Irradiated Fuels Examination } \\
\text { Laboratory }\end{array}$ & Metals \& Ceramics & $05 / 10 / 2001$ & $\begin{array}{l}\text { Carlo Melbihess } \\
\text { David Skipper }\end{array}$ & Charles DeVore \\
\hline Jeskie, K.B. & $4500 \mathrm{~S}$ & Central Research \& Administration & $\begin{array}{l}\text { Chemical \& Analytical } \\
\text { Sciences Division }\end{array}$ & $04 / 26 / 2001$ & Terry Bonine & $\begin{array}{l}\text { Kim Jeskie } \\
\text { Bruce Moyer }\end{array}$ \\
\hline Baldwin, R.H. & $4500 S$ & $\begin{array}{l}\text { Central Research \& Administration } \\
\text { (CIS-Publications) }\end{array}$ & Metals \& Ceramics & $04 / 23 / 2001$ & Glenn Anderson & $\begin{array}{l}\text { Bill Miller } \\
\text { Randy Ogle }\end{array}$ \\
\hline Dunn, W.C. & $4500 \mathrm{~S}$ & $\begin{array}{l}\text { Central Research \& Administration } \\
\text { (CIS-Publications) }\end{array}$ & Life Sciences & $04 / 26 / 2001$ & Nancy Dailey & $\begin{array}{l}\text { R.James/J.Swenson/ } \\
\text { D.Embleton/J.Hardt }\end{array}$ \\
\hline Sy, R.L. & 4501 & Radiochemistry Lab & Chemical Technology & $05 / 11 / 2001$ & $\begin{array}{l}\text { Carlo Melbihess } \\
\text { David Skipper }\end{array}$ & Ron Sy \\
\hline Peacher, R.F. & 5505 & $\begin{array}{l}\text { Transuranium Research } \\
\text { Laboratory }\end{array}$ & $\begin{array}{l}\text { Chemical and Analytical } \\
\text { Sciences }\end{array}$ & $05 / 02 / 2001$ & $\begin{array}{l}\text { Carol Scott } \\
\text { Jerry Hunt }\end{array}$ & $\begin{array}{l}\text { Rob Peacher } \\
\text { Steffon Riser }\end{array}$ \\
\hline Lee, J.E. & 7900 & High-Flux Isotope Reactor & Research Reactors & & 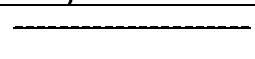 & 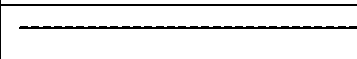 \\
\hline Patton, B.D. & 7920 & $\begin{array}{l}\text { Radiochemical Engineering } \\
\text { Development Center (REDC) }\end{array}$ & Chemical Technology & $05 / 03 / 2001$ & $\begin{array}{l}\text { Hans Vogel } \\
\text { Carlo Melbihess }\end{array}$ & $\begin{array}{l}\text { Dean Campbell } \\
\text { Fred Chatlin }\end{array}$ \\
\hline Patton, B.D. & 7930 & $\begin{array}{l}\text { Radiochemical Engineering } \\
\text { Development Center (REDC) }\end{array}$ & Chemical Technology & $05 / 03 / 2001$ & $\begin{array}{l}\text { Hans Vogel } \\
\text { Carlo Melbihess }\end{array}$ & $\begin{array}{l}\text { Dean Campbell } \\
\text { Fred Chatlin }\end{array}$ \\
\hline
\end{tabular}


Legacy Transition Project

Facility/ Site Characterization and Vulnerability Assessment

Priority 2 Facility Walkdowns

\begin{tabular}{|c|c|c|c|c|c|c|}
\hline $\begin{array}{l}\text { FACILITY } \\
\text { MANAGER'S } \\
\text { NAME }\end{array}$ & $\begin{array}{l}\text { FACILITY } \\
\text { ID } \\
\text { NUMBER }\end{array}$ & FACILITY NAME & ORGANIZATION & $\begin{array}{l}\text { INTERVIEW } \\
\text { DATE }\end{array}$ & $\begin{array}{l}\text { INTERVIEW } \\
\text { LEAD }\end{array}$ & FACILTY LEAD \\
\hline Cline, S.R. & 1059 & $\begin{array}{l}\text { Health Effects Information Office } \\
\text { Building }\end{array}$ & Environmental Sciences & $06 / 08 / 2001$ & David Skipper & Steve Cline \\
\hline Coker. J.D. & 1503 & Environmental Systems Laboratory & Plant \& Equipment & $06 / 15 / 2001$ & David Skipper & Steve Cline \\
\hline Cline, S.R. & 1504 & Aquatic Ecology Laboratory & Environmental Sciences & $05 / 16 / 2001$ & David Skipper & Steve Cline \\
\hline Cline, S.R. & 1505 & Environmental Sciences Laboratory & Environmental Sciences & $05 / 16 / 2001$ & David Skipper & Steve Cline \\
\hline Cline, S.R. & 1506 & Plant Sciences Laboratory & Environmental Sciences & $05 / 16 / 2001$ & David Skipper & Steve Cline \\
\hline Dothard, S & 2000 & Solid State Annex & Office of Quality Services & $06 / 19 / 2001$ & Carlo Melbihess & Spike Dothard \\
\hline Dothard, S & 2001 & Information Center Complex & $\begin{array}{l}\text { Office of Quality Program \& } \\
\text { Inspection }\end{array}$ & $06 / 19 / 2001$ & Carlo Melbihess & Spike Dothard \\
\hline Dothard, S & 2024 & Quality Programs \& Inspection Offices & $\begin{array}{l}\text { Office of Quality Program \& } \\
\text { Inspection }\end{array}$ & 06/19/2001 & Carlo Melbihess & Spike Dothard \\
\hline Baity, J.D. & 2500 & $\begin{array}{l}\text { Protective Services Head-quarters \& } \\
\text { Fire Station }\end{array}$ & $\begin{array}{l}\text { Office of Laboratory } \\
\text { Protection }\end{array}$ & $06 / 15 / 2001$ & Dirk Van Hoesen & David Baity \\
\hline Baxter, J & 2519 & Steam Plant & Plant \& Equipment & $05 / 22 / 2001$ & Glenn Anderson & Jim Baxter \\
\hline Baxter, J & $2519 A$ & $\begin{array}{l}\text { Steam Plant Standby Emergency } \\
\text { Generator }\end{array}$ & Plant \& Equipment & $05 / 22 / 2001$ & Glenn Anderson & Jim Baxter \\
\hline McCulley, P.H. & 2523 & Decontamination Laundry & Plant \& Equipment & $06 / 25 / 2001$ & Dirk Van Hoesen & Al Hendricks \\
\hline Sy, R.L. & 2528 & WHPP Development Facility & $\begin{array}{l}\text { Chemical Technology } \\
\text { Division }\end{array}$ & $06 / 21 / 2001$ & Dirk Van Hoesen & Betty Evans \\
\hline Mink, R.M. & 2547 & Machine Maintenance Shop & Plant \& Equipment & $06 / 22 / 2001$ & Dirk Van Hoesen & Robert Mink \\
\hline Baxter, J.L. & 2643 & Chlorinator Building & Plant \& Equipment & $05 / 15 / 2001$ & David Skipper & Jim Baxter \\
\hline Haynes, T.E. & 3003 & $\begin{array}{l}\text { Surface Modification \& } \\
\text { Characterization Facility }\end{array}$ & Solid State & $06 / 28 / 2001$ & David Skipper & Dale Hensley \\
\hline Withrow, S.P. & 3003 & $\begin{array}{l}\text { Surface Modification \& } \\
\text { Characterization Facility }\end{array}$ & Solid State & $06 / 28 / 2001$ & David Skipper & Dale Hensley \\
\hline Baldwin, R.H. & 3012 & Rolling Mill & Metals \& Ceramics & $05 / 22 / 2001$ & David Skipper & Ron Baldwin \\
\hline Dothard, W.I. & 3017 & Annex & Office of Quality Services & $06 / 19 / 2001$ & Carlo Melbihess & $\begin{array}{l}\text { Spike Dothard } \\
\text { Sam Wood }\end{array}$ \\
\hline Withrow, S.P. & $3025 \mathrm{M}$ & Solid State Laboratory & Solid State & $06 / 28 / 2001$ & David Skipper & David Poker \\
\hline
\end{tabular}


Legacy Transition Project

Facility/ Site Characterization and Vulnerability Assessment

Priority 2 Facility Walkdowns

\begin{tabular}{|c|c|c|c|c|c|c|}
\hline $\begin{array}{l}\text { FACILITY } \\
\text { MANAGER'S } \\
\text { NAME }\end{array}$ & $\begin{array}{l}\text { FACILTTY } \\
\text { ID } \\
\text { NUMBER }\end{array}$ & FACILITY NAME & ORGANIZATION & $\begin{array}{l}\text { INTERVIEW } \\
\text { DATE }\end{array}$ & $\begin{array}{l}\text { INTERVIEW } \\
\text { LEAD }\end{array}$ & FACILITY LEAD \\
\hline Patton, B.D. & 3034 & Radioisotope Area Services & Chemical Technology & $05 / 29 / 2001$ & David Skipper & John Norman \\
\hline Shelton, J.H. & 3036 & $\begin{array}{l}\text { Radioisotope Material Shipping \& } \\
\text { Packaging }\end{array}$ & Logistical Services & $06 / 01 / 2001$ & David Skipper & Jeff Shelton \\
\hline Patton, B.D. & 3037 & Chemical Technology Offices & Chemical Technology & $06 / 25 / 2001$ & Dirk Van Hoesen & Dan Ramey \\
\hline Coker, J & 3044 & Research Services Field Shop & Plant \& Equipment & $05 / 24 / 2001$ & Glenn Anderson & Sam Turner/Jerry Coker \\
\hline Cleveland, P.G. & $3047 \mathrm{~A}$ & Isotope Technology Building & $\begin{array}{l}\text { Environmental Protection \& } \\
\text { Waste Services }\end{array}$ & $06 / 18 / 2001$ & Dirk Van Hoesen & $\begin{array}{l}\text { Pat Cleveland } \\
\text { Herman Phillips }\end{array}$ \\
\hline Guymon, K & 3074 & Interim Manipulator Repair Facility & Plant \& Equipment & $05 / 24 / 2001$ & Glenn Anderson & $\begin{array}{l}\text { K.E. Guymon/Jim Ayers/ } \\
\text { Gary Wright }\end{array}$ \\
\hline Christen, D.K. & 3080 & Superconductivity Laboratory & Solid State & $06 / 28 / 2001$ & David Skipper & David Poker \\
\hline Patton, B.D. & 3091 & Cell Off-Gas Filter House for 3019 & Chemical Technology & $04 / 25 / 2001$ & $\begin{array}{l}\text { Bill Miller } \\
\text { Steve Handley }\end{array}$ & $\begin{array}{l}\text { Alan Krichinsky/Ray Bond/ } \\
\text { Brad Patton/Billy Starnes }\end{array}$ \\
\hline Patton, B.D. & 3108 & Filter House for 3019 & Chemical Technology & $04 / 25 / 2001$ & $\begin{array}{l}\text { Bill Miller } \\
\text { Steve Handley }\end{array}$ & $\begin{array}{l}\text { Alan Krichinsky/Ray Bond/ } \\
\text { Brad Patton/Billy Starnes }\end{array}$ \\
\hline Childs, P.W. & 3114 & Efficiency Research Laboratory & Energy & $06 / 25 / 2001$ & Dirk Van Hoesen & Phil Childs \\
\hline Patton, B.D. & 3121 & Cell Off-Gas Filter House for 3019 & Chemical Technology & $04 / 25 / 2001$ & $\begin{array}{l}\text { Bill Miller } \\
\text { Steve Handley }\end{array}$ & $\begin{array}{l}\text { Alan Krichinsky/Ray Bond/ } \\
\text { Brad Patton/Billy Starnes }\end{array}$ \\
\hline Withrow, S & 3137 & Surface Science Lab & Solid State & $06 / 28 / 2001$ & David Skipper & David Poker \\
\hline Childs, P.W. & 3144 & Roof Research Center & Energy & $06 / 25 / 2001$ & Dirk Van Hoesen & Phil Childs \\
\hline Boatner, L & 3150 & $\begin{array}{l}\text { Ceramics \& Thin Film Growth } \\
\text { Laboratory }\end{array}$ & Solid State & $06 / 22 / 2001$ & Dirk Van Hoesen & Brian Sales \\
\hline Hodges, H.U. & 3502 & East Research Service Center & Plant \& Equipment & $06 / 21 / 2001$ & Dirk Van Hoesen & Greg Palko \\
\hline Patton, B.D. & 3503 & $\begin{array}{l}\text { High Radiation Level Chemical } \\
\text { Engineering Laboratory }\end{array}$ & Chemical Technology & $06 / 20 / 2001$ & Carlo Melbihess & Charles (Ed) Benson \\
\hline Holbert, S & 3504 & Geosciences Laboratory & $\begin{array}{l}\text { Laboratory Protection } \\
\text { Division }\end{array}$ & $06 / 21 / 2001$ & Carlo Melbihess & Sheila Holbert \\
\hline Ewing, P.D. & 3508 & I\&C Metrology \& Calibration & $\begin{array}{l}\text { Instrumentation \& Controls } \\
\text { Division }\end{array}$ & $06 / 19 / 2001$ & Carlo Melbihess & Paul Ewing \\
\hline Baldwin, R.H. & 3534 & Storage Building & Metals \& Ceramics & $06 / 19 / 2001$ & Hans Vogel & $\begin{array}{l}\text { Bill Miller } \\
\text { Ron Baldwin }\end{array}$ \\
\hline Evans, B.S. & 3541 & Engineering Development Laboratory & Chemical Technology & $06 / 21 / 2001$ & Dirk Van Hoesen & Betty Evans \\
\hline
\end{tabular}


Legacy Transition Project

Facility/ Site Characterization and Vulnerability Assessment

Priority 2 Facility Walkdowns

\begin{tabular}{|c|c|c|c|c|c|c|}
\hline $\begin{array}{l}\text { FACILITY } \\
\text { MANAGER'S } \\
\text { NAME }\end{array}$ & $\begin{array}{l}\text { FACILTTY } \\
\text { ID } \\
\text { NUMBER }\end{array}$ & FACILITY NAME & ORGANIZATION & $\begin{array}{l}\text { INTERVIEW } \\
\text { DATE }\end{array}$ & $\begin{array}{l}\text { INTERVIEW } \\
\text { LEAD }\end{array}$ & FACILITY LEAD \\
\hline Evans, B.S. & $3544 \mathrm{~A}$ & ORNL Waste Water Treatment Facility & Chemical Technology & $06 / 21 / 2001$ & Dirk Van Hoesen & Betty Evans \\
\hline Pruitt, W.J. & 3550 & Research Materials Preparation & $\begin{array}{l}\text { Operational Safety Services } \\
\text { Division }\end{array}$ & $06 / 20 / 2001$ & Carlo Melbihess & Jay Pruitt \\
\hline Cox, J.C. & 3587 & Instrument Laboratory Annex & $\begin{array}{l}\text { Instrumentation \& Controls } \\
\text { Division }\end{array}$ & $06 / 28 / 2001$ & Dirk Van Hoesen & $\begin{array}{l}\text { John Watson } \\
\text { Mitchell Childs (SCG) }\end{array}$ \\
\hline Evans, B.S. & 3592 & Coal Conversion Facility & Chemical Technology & $06 / 21 / 2001$ & Dirk Van Hoesen & Betty Evans \\
\hline \multirow[t]{2}{*}{ Patton, B.D. } & 3597 & Hot Storage Garden & Chemical Technology & $05 / 29 / 2001$ & David Skipper & John Norman \\
\hline & $4500 \mathrm{~N}$ & Central Research \& Administration & $\begin{array}{l}\text { Analytical Services } \\
\text { Organization }\end{array}$ & $06 / 19 / 2001$ & David Skipper & Hurtis Hodges \\
\hline Sy, R.L. & $4500 \mathrm{~N}$ & Central Research \& Administration & Chemical Technology & $06 / 19 / 2001$ & David Skipper & Hurtis Hodges \\
\hline Jeskie, K.B. & $4500 \mathrm{~N}$ & Central Research \& Administration & $\begin{array}{l}\text { Chemical \& Analytical } \\
\text { Sciences Division }\end{array}$ & $06 / 19 / 2001$ & David Skipper & Hurtis Hodges \\
\hline Pike, D.H & $4500 \mathrm{~N}$ & Central Research \& Administration & $\begin{array}{l}\text { Computational Physics \& } \\
\text { Engineering }\end{array}$ & $06 / 19 / 2001$ & David Skipper & Hurtis Hodges \\
\hline \multirow[t]{7}{*}{ Pike, D.H } & $4500 \mathrm{~N}$ & Central Research \& Administration & $\begin{array}{l}\text { Computing Information } \\
\text { Networking }\end{array}$ & 06/19/2001 & David Skipper & Hurtis Hodges \\
\hline & $4500 \mathrm{~N}$ & Central Research \& Administration & Facility Operations & $06 / 19 / 2001$ & David Skipper & Hurtis Hodges \\
\hline & $4500 \mathrm{~N}$ & Central Research \& Administration & Energy & $06 / 19 / 2001$ & David Skipper & Hurtis Hodges \\
\hline & $4500 \mathrm{~N}$ & Central Research \& Administration & Engineering & $06 / 19 / 2001$ & David Skipper & Hurtis Hodges \\
\hline & $4500 \mathrm{~N}$ & Central Research \& Administration & Health & $06 / 19 / 2001$ & David Skipper & Hurtis Hodges \\
\hline & $4500 \mathrm{~N}$ & Central Research \& Administration & Life Sciences & $06 / 19 / 2001$ & David Skipper & Hurtis Hodges \\
\hline & $4500 \mathrm{~N}$ & Central Research \& Administration & Physics & $06 / 19 / 2001$ & David Skipper & Hurtis Hodges \\
\hline Sy, R.L. & 4505 & Experimental Engineering & Chemical Technology & $06 / 28 / 2001$ & Glenn Anderson & $\begin{array}{l}\text { John Norman } \\
\text { Ron Sy }\end{array}$ \\
\hline Baldwin, R.H. & 4508 & Metals \& Ceramics Laboratory & Metals \& Ceramics & $06 / 19 / 2001$ & Hans Vogel & $\begin{array}{l}\text { Bill Miller } \\
\text { Ron Baldwin }\end{array}$ \\
\hline Baldwin, R.H. & 4515 & $\begin{array}{l}\text { High Temperature Materials } \\
\text { Laboratory }\end{array}$ & Metals \& Ceramics & $06 / 19 / 2001$ & Hans Vogel & $\begin{array}{l}\text { Bill Miller } \\
\text { Ron Baldwin }\end{array}$ \\
\hline Baldwin, R.H. & 5500 & $\begin{array}{l}\text { High-Voltage Accelerator Laboratory, } \\
\text { M\&C South Office Annex }\end{array}$ & Metals \& Ceramics & $06 / 25 / 2001$ & David Skipper & Eric Stroud \\
\hline
\end{tabular}


Legacy Transition Project

Facility/ Site Characterization and Vulnerability Assessment

Priority 2 Facility Walkdowns

\begin{tabular}{|c|c|c|c|c|c|c|}
\hline $\begin{array}{l}\text { FACILITY } \\
\text { MANAGER'S } \\
\text { NAME }\end{array}$ & $\begin{array}{l}\text { FACILITY } \\
\text { ID } \\
\text { NUMBER }\end{array}$ & FACILITY NAME & ORGANIZATION & $\begin{array}{l}\text { INTERVIEW } \\
\text { DATE }\end{array}$ & $\begin{array}{l}\text { INTERVIEW } \\
\text { LEAD }\end{array}$ & FACILTY LEAD \\
\hline Allman, S.L. & 5500 & Photophysics & Life Sciences & $06 / 25 / 2001$ & David Skipper & Eric Stroud \\
\hline Cook, S.W. & 5500 & Triple Ion Accelerator Facility & Metals \& Ceramics & $06 / 25 / 2001$ & David Skipper & Eric Stroud \\
\hline Vane, C.R & 5500 & $\begin{array}{l}\text { Negative Ion Test Bench Facility, } \\
\text { EN Tandem Accelerator }\end{array}$ & Physics & $06 / 25 / 2001$ & David Skipper & Eric Stroud \\
\hline Lammert. S.A. & $5510 \mathrm{~A}$ & $\begin{array}{l}\text { Inorganic Mass Spectrometry } \\
\text { Labortory (MSL) }\end{array}$ & $\begin{array}{l}\text { Chemical \& Analytical } \\
\text { Sciences Division }\end{array}$ & $06 / 22 / 2001$ & David Skipper & Kim Jeskie \\
\hline Lammert, S.A. & $5510 \mathrm{P}$ & $\begin{array}{l}\text { Organic \& Biological Mass } \\
\text { Spectrometry Laboratory }\end{array}$ & $\begin{array}{l}\text { Chemical \& Analytical } \\
\text { Sciences Division }\end{array}$ & $06 / 22 / 2001$ & David Skipper & Kim Jeskie \\
\hline Mills, G.D. & 6000 & Holifield Radioactive Ion Beam Facility & Physics & $06 / 21 / 2001$ & David Skipper & Sandra Kennedy \\
\hline Meigs, M.J. & 6005 & Gas Compressor House 6000 & Physics & $06 / 21 / 2001$ & David Skipper & Sandra Kennedy \\
\hline Talley, W.D. & 6010 & Oak Ridge Electron Linar Accelerator & Plant \& Equipment & $06 / 29 / 2001$ & David Skipper & Sandra Kennedy \\
\hline Larson, D.C. & 6010 & Electron Linear Accelerator & Physics & $06 / 29 / 2001$ & David Skipper & Sandra Kennedy \\
\hline Riley, B.A. & 6010 & Oak Ridge Electron Linear Accelerator & $\begin{array}{l}\text { Computer Science \& } \\
\text { Mathematics }\end{array}$ & $06 / 29 / 2001$ & David Skipper & Sandra Kennedy \\
\hline Butler, J.L. & 7040 & Gas Cylinder Storage & Logistical Services & $06 / 21 / 2001$ & Dirk Van Hoesen & Jerry Butler \\
\hline Lee, J.E. & 7902 & HFIR Cooling Tower & Research Reactors & $06 / 29 / 2001$ & Hans Vogel & George Flanagan \\
\hline Lee, J.E. & 7903 & Cooling Tower Equipment Building & Research Reactors & $06 / 29 / 2001$ & Hans Vogel & George Flanagan \\
\hline Patton, B.D. & $7911 \mathrm{~A}$ & Electrical Switch Room (7920) & Chemical Technology & $06 / 29 / 2001$ & Hans Vogel & Brad Patton \\
\hline Lee, J.E. & 7913 & Filter Pit (for 7911 Stack) & Research Reactors & $06 / 29 / 2001$ & Hans Vogel & George Flanagan \\
\hline Wright. P.F. & 7917 & $\begin{array}{l}\text { Research Reactors Division Office } \\
\text { Building }\end{array}$ & Research Reactors & $06 / 08 / 2001$ & David Skipper & Mary Dunsmore \\
\hline Patton, B.D. & 7932 & Waste Sample Building for 7930 & Chemical Technology & $06 / 29 / 2001$ & Hans Vogel & Brad Patton \\
\hline Patton, B.D. & 7957 & Office Trailer for 7920 & Chemical Technology & $06 / 29 / 2001$ & Hans Vogel & Brad Patton \\
\hline Cotter, J.L. & $7964 G$ & HFIR Operations/Change House & Research Reactors & $06 / 29 / 2001$ & Hans Vogel & George Flanagan \\
\hline Aaron, W.S. & $9204-3$ & Isotope Separations & Chemical Technology & $06 / 15 / 2001$ & $\begin{array}{l}\text { Hans Vogel } \\
\text { Carlo Melbihess }\end{array}$ & Scott Aaron \\
\hline
\end{tabular}




\section{Exhibit 3 - Vulnerability and Observation Summary}

\begin{tabular}{|c|c|c|}
\hline Section & & Vulnerability \\
\hline 2.1 .3 & $\begin{array}{l}\text { Management System Description: } \\
\text { Environmental Management }\end{array}$ & $\begin{array}{l}\text { At the time of this review, interviews and evidence gathered indicate that these policies, with the exception of those } \\
\text { focused on "compliance," have yet to be ingrained or active in the culture of the Laboratory. }\end{array}$ \\
\hline \multirow[t]{5}{*}{2.1 .4} & \multirow[t]{5}{*}{ Environmental Planning } & $\begin{array}{l}\text { Evidence gathered during this assessment indicates that in the past, senior management did not have the } \\
\text { environmental vulnerability data that it needed to make appropriate judgments and set priorities to achieve the goal } \\
\text { of long-term operational sustainability of the Laboratory. }\end{array}$ \\
\hline & & $\begin{array}{l}\text { This assessment identified a number of environmental vulnerabilities that were well known by the divisions for } \\
\text { many years, but these issues had not consistently been elevated through the planning process to senior management }\end{array}$ \\
\hline & & $\begin{array}{l}\text { Comprehensive facility process evaluations and environmental pathway analysis, required by the Pollution } \\
\text { Prevention and Waste Minimization Program and the Integrated Safety Management Program, have not been } \\
\text { conducted for each facility or process. }\end{array}$ \\
\hline & & $\begin{array}{l}\text { No central repository exists nor is any one person responsible for integrating and coordinating the environmental } \\
\text { planning and permit-related documents. }\end{array}$ \\
\hline & & $\begin{array}{l}\text { No single document describing a comprehensive environmental protection strategy provides a clear picture of } \\
\text { environmental planning that could be used by senior management in an integrated planning process for the } \\
\text { Laboratory. }\end{array}$ \\
\hline \multirow[t]{2}{*}{2.1 .5} & \multirow[t]{2}{*}{ Sink and Drain Program } & $\begin{array}{l}\text { Because of funding limitations, there was no formal, independent oversight of the initial study to validate that each } \\
\text { organization had adhered fully to the guidance provided; however, some oversight data available through the } \\
\text { Operational Awareness Program, provides some confidence that the sink and drain study was reasonably } \\
\text { comprehensive. }\end{array}$ \\
\hline & & $\begin{array}{l}\text { Considerable room for improvement remains in the area of potential discharges to the storm water system due to } \\
\text { inappropriate storage of materials near storm drains. }\end{array}$ \\
\hline 2.1 .6 & Chemical Management Program & $\begin{array}{l}\text { FEVA facility walkdowns validated the existence of large quantities of excess chemicals in the workplace, large } \\
\text { quantities of legacy wastes in some workplaces, inaccuracies in the hazardous materials inventory system, and } \\
\text { inappropriately stored chemicals. Initiatives underway are mitigating these issues. }\end{array}$ \\
\hline 2.1 .7 & $\begin{array}{l}\text { Pollution Prevention and Waste } \\
\text { Minimization Program }\end{array}$ & Few divisions have conducted process evaluations and pathway analysis as required by the P2/WM requirements. \\
\hline 2.1 .8 & Groundwater Protection Program & $\begin{array}{l}\text { A UT-Battelle Groundwater Protection Program Plan exists but is currently under review and may require revision } \\
\text { to reflect the results of the Independent Review of the High Flux Isotope Reactor Tritium Leak at the Oak Ridge } \\
\text { National Laboratory. }\end{array}$ \\
\hline \multirow[t]{2}{*}{2.2 .1} & \multirow[t]{2}{*}{ Infrastructure Overview } & $\begin{array}{l}\text { The majority of current ORNL space is substandard and needs to be replaced or upgraded in order to support the } \\
\text { long-term research mission of the Laboratory. ORNL has one of the oldest physical plants in the DOE laboratory } \\
\text { system. }\end{array}$ \\
\hline & & $\begin{array}{l}\text { A significant challenge facing senior management is the effective integration and coordination of the DOE Science- } \\
\text { funded Facility Revitalization Project, the DOE EM-funded Environmental Restoration Program, and the DOE } \\
\text { Facility Transition Program. }\end{array}$ \\
\hline
\end{tabular}


Legacy Transition Project

Facility/ Site Characterization and Vulnerability Assessment

\begin{tabular}{|c|c|c|}
\hline Section & & Vulnerability \\
\hline 2.2 .2 & Potable Water Supply & $\begin{array}{l}\text { The current system is known to leak out water, especially in the older process areas within the plant, but the leakage } \\
\text { volume has not been formally quantified. This leakage could move radioactive material and other contaminants into } \\
\text { groundwater and surface water by finding various pathways, including the storm drains, sewer, and process waste. }\end{array}$ \\
\hline \multirow[t]{2}{*}{2.2 .4} & \multirow[t]{2}{*}{ Process Waste System } & $\begin{array}{l}\text { The integrity of the PW system piping from UT-Battelle facilities to connecting manholes remains a vulnerability. } \\
\text { Leaks have been detected in this type of pipe over the years, and it is likely that some of the remaining clay pipe is } \\
\text { leaking. }\end{array}$ \\
\hline & & $\begin{array}{l}\text { An additional potential environmental vulnerability arises from the inability of each facility or operation to } \\
\text { quantitatively demonstrate that its discharges to the PW system are meeting the required BJC waste acceptance } \\
\text { criteria (WAC) for the system. Most facilities do not have the capability to quantitatively measure the flow and } \\
\text { concentration of their discharges to the PW system }\end{array}$ \\
\hline 2.2 .5 & Low-Level Liquid Waste System & $\begin{array}{l}\text { Environmental issues associated with legacy wastes generated as a result of operating the old system or resulting } \\
\text { from the disconnections during the upgrade are being addressed by the DOE EM Program, but this area was not } \\
\text { investigated during this assessment. }\end{array}$ \\
\hline \multirow[t]{3}{*}{2.2 .6} & \multirow[t]{3}{*}{ Storm Water System } & $\begin{array}{l}\text { The collection system has resulted in the existence of } 146 \text { NPDES-permitted storm water outfalls discharging into } \\
\text { the receiving streams. To comply with ORNL's NPDES permit, each of these outfalls must be periodically sampled } \\
\text { and characterized to determine the makeup of the discharge stream and to ensure that it complies with permit } \\
\text { requirements. }\end{array}$ \\
\hline & & $\begin{array}{l}\text { Infiltration of water from groundwater, process waste, sanitary sewer, and potable water systems cannot be ruled } \\
\text { out, potentially introducing contaminants to the system. Detection of this low-level chronic introduction and release } \\
\text { of contaminants is difficult because of the volumetric dilution from the single-pass cooling water. }\end{array}$ \\
\hline & & $\begin{array}{l}\text { The last and probably the most significant environmental vulnerability for the storm water system is the continued } \\
\text { potentials for spills from the inappropriate storage of chemicals and oil products adjacent to storm drains without } \\
\text { proper secondary containment. }\end{array}$ \\
\hline 2.2 .7 & $\begin{array}{l}\text { Sanitary Sewage Collection and } \\
\text { Treatment }\end{array}$ & $\begin{array}{l}\text { The detection of radioactive materials on occasion in the sewer treatment plant sludge provides additional evidence } \\
\text { that there may be infiltration from the groundwater into the sewer system. The source of this infiltrated water } \\
\text { (ground or potable) cannot be definitively determined at this time because of the unknown physical condition of the } \\
\text { pipes and large amount of legacy contamination. }\end{array}$ \\
\hline \multirow[t]{3}{*}{2.2 .8} & \multirow[t]{3}{*}{ Gaseous Waste Systems } & $\begin{array}{l}\text { A potential environmental vulnerability exists with this vent and cell off-gas system because some facilities and } \\
\text { operations are unable to quantitatively validate that their discharges to the ventilation system meet the required BJC } \\
\text { WAC for the system. }\end{array}$ \\
\hline & & $\begin{array}{l}\text { Additional environmental vulnerabilities that may exist with the gaseous waste system involve the current physical } \\
\text { condition of the system, the infiltration of water into ductwork and sumps, and the communication of potential } \\
\text { contaminants to other systems (e.g., storm water). }\end{array}$ \\
\hline & & $\begin{array}{l}\text { It is unclear if all of the discharges from moisture drains conform to the sink and drain program or have been } \\
\text { identified and determined to be appropriate. }\end{array}$ \\
\hline 2.2 .9 & Solid Waste Disposal & $\begin{array}{l}\text { Large numbers of B-25 boxes of legacy solid low-level waste (SLLW) are stored in BJC facilities at ORNL as well } \\
\text { as in the main plant area. SLLW is currently stored in multiple facilities within Solid Waste Storage Area (SWSA) } \\
5 \text { and SWSA } 6 .\end{array}$ \\
\hline
\end{tabular}


Legacy Transition Project

Facility/ Site Characterization and Vulnerability Assessment

\begin{tabular}{|c|c|c|}
\hline & & $\begin{array}{l}\text { Remotely handled }(\mathrm{RH}) \text { radioactive wastes are not being disposed of in a timely manner. This creates potential } \\
\text { environmental vulnerabilities and unnecessary exposures to staff. }\end{array}$ \\
\hline & & $\begin{array}{l}\text { Hazardous wastes may be accumulating now in Satellite Accumulation Areas (SAAs) in a manner that may be } \\
\text { creating other safety and health vulnerabilities. }\end{array}$ \\
\hline 2.2 .10 & Vacuum System Moisture Traps & $\begin{array}{l}\text { Hazardous and mixed wastes may be collected in these traps, especially when there is readily available access to } \\
\text { the vacuum system ports in laboratory chemical hoods and there are no controls on the access to the vacuum system } \\
\text { ports. }\end{array}$ \\
\hline 2.2 .11 & Single-Pass Cooling Water & $\begin{array}{l}\text { UT-Battelle generators do not have data (flow and concentration) at the point of discharge to the PW system and } \\
\text { rely on generator training and administrative controls to satisfy the WAC. Also, UT-Battelle does not periodically } \\
\text { assess the effectiveness of these administrative controls. }\end{array}$ \\
\hline & & $\begin{array}{l}\text { Attempts to consolidate chlorine containing discharges to the storm waste system have met with little success } \\
\text { because of inadequate funding. }\end{array}$ \\
\hline & & No comprehensive cost-benefit analysis of the extensive use of single-pass cooling water has been conducted. \\
\hline & & $\begin{array}{l}\text { The large volume of single-pass cooling water may be enabling communication and transport of contaminants } \\
\text { among storm water, sanitary sewer, process waste and groundwater. }\end{array}$ \\
\hline 2.2 .12 & Surface and Subsurface Contamination & $\begin{array}{l}\text { Significant evidence exists that plants, animals, and insects provide a pathway for the migration of surface and } \\
\text { subsurface legacy contamination and are resulting in localized contamination incidents }\end{array}$ \\
\hline 2.5 .1 & Building 3026 & $\begin{array}{l}\text { The northwest exterior of Building } 2026 \text { has an underground concrete filter exhaust pit for the main exhaust system } \\
\text { of the building that accumulates water that could leak to the environment. }\end{array}$ \\
\hline & & The main exhaust stack has a drain in the bottom that was recently rerouted to the PW system. \\
\hline & & $\begin{array}{l}\text { The old LLLW storage tank of uncertain integrity, currently under the responsibility of BJC, contains 3-50 gal of } \\
\text { sludge that contains polychlorinated biphenyl (PCB) oil and about } 5 \mathrm{lb} \text { of elemental mercury. }\end{array}$ \\
\hline & & $\begin{array}{l}\text { Numerous drain systems connecting to the PW system have uncertain integrity, resulting in the potential for } \\
\text { leakage to the environment. }\end{array}$ \\
\hline & Building 3019A & A deteriorating out-of-service contaminated conveyor is located on the building roof. \\
\hline & & An external 1950's vintage 36-in-diam mild steel cell off-gas (COG) duct shows signs of deterioration. \\
\hline & & Groundwater leaking into the contaminated filter bunkers 3091 and 3108 requires regular draining. \\
\hline & & $\begin{array}{l}\text { An out-of-service, underground LLLW drain line has left legacy contamination in the } 3020 \text { stack area requiring } \\
\text { enhanced surveillance and maintenance (S\&M) to prevent the spread of contamination. }\end{array}$ \\
\hline & & $\begin{array}{l}\text { The exterior south wall is a three-story block structure with no anchoring along its elevation, making the wall } \\
\text { vulnerable to seismic and wind events. }\end{array}$ \\
\hline & & Three external vessel off-gas (VOG) lines (that are highly contaminated internally) show signs of deterioration. \\
\hline & & $\begin{array}{l}\text { The VOG is interconnected to the COG, providing the potential for exchange of unfiltered off-gas between the } \\
\text { systems. }\end{array}$ \\
\hline & & Inactive Building 3121 (filter house) is sealed but is highly contaminated inside. \\
\hline & & $\begin{array}{l}\text { Sanitary, storm, and process waste drains are made of vitrified clay or cast iron and are presumed to leak to the } \\
\text { environment. }\end{array}$ \\
\hline
\end{tabular}


Legacy Transition Project

Facility/ Site Characterization and Vulnerability Assessment

Building 3025E

Building 3027

Building 3047

Perchlorates above the action level concentrations have been found in the off-gas manifold in adjacent 3019B (managed by BJC) that is connected to and served by the 3019A laboratory off-gas (LOG) system. Some perchlorate contamination has been detected in the 3019A LOG ducts slightly above the ORNL threshold. P-24 tank (located in a mostly below-grade pit) contains approximately 15,000 L of nitrate solution containing two metric tons of thorium contaminated with ${ }^{233} \mathrm{U}$.

Manholes adjacent to the building contain low levels of contamination.

Sealed storage wells contain internal contamination but the wells are dry.

Request has been submitted to replace deteriorated steam piping.

The drain lines from the rooms to the storage tank are single-contained lines located below the building slab that do not have integrity checks performed regularly.

Confirmation of integrity of two sealed barriers for fissionable material as described in the facility safety documentation needs to be performed by the Chemical Technology Division (CTD).

A seismic evaluation indicated that portions of the above-ground off-gas system and glove boxes may be vulnerable to earthquakes or wind.

A HEPA filter housing on the roof shows signs of deterioration and presents the potential for leakage of contaminated off-gas.

A planned upgrade to provide the capability to transport liquid waste to the LLLW system will utilize a portion of an inactive LLLW drain that may provide a pathway to the environment and may present regulatory issues.

A significant amount of solid RH LLW has accumulated in the cell charge area, presenting potential combustible material and ALARA problems.

Several opportunities for "housekeeping" improvements were noted.

Process water outlets in cells and glove boxes present a low probability potential for contaminant migration to the potable water system if a backflow preventer were to fail.

Interface agreements have not yet been established for changing filters in a HEPA unit for the 3047 hot off-gas system that are located in Building 3028 (managed by BJC).

Equipment needed to load spent fuel cans from 3047 into storage wells at SWSA 5 is not currently available and is delaying needed facility upgrades to meet programmatic needs.

Building 3525

An underground oil storage tank is buried on the west exterior of the building that is assumed to be empty with no radiological concerns.

The first floor mechanical room houses a chiller that utilizes ethylene glycol and has drains that are connected to the PW system.

An inactive LLLW storage tank (F501) isolated from the building and decommissioned in 1996 and now under the responsibility of BJC contains approximately $20 \%$ by volume of residual LLLW contaminated with PCB.

An inactive process waste tank (F202) that was tied into the building hot off-gas system is the responsibility of UTBattelle.

A contaminated sump in the basement of the building is drained manually into 55-gal drums for transport to

treatment. 


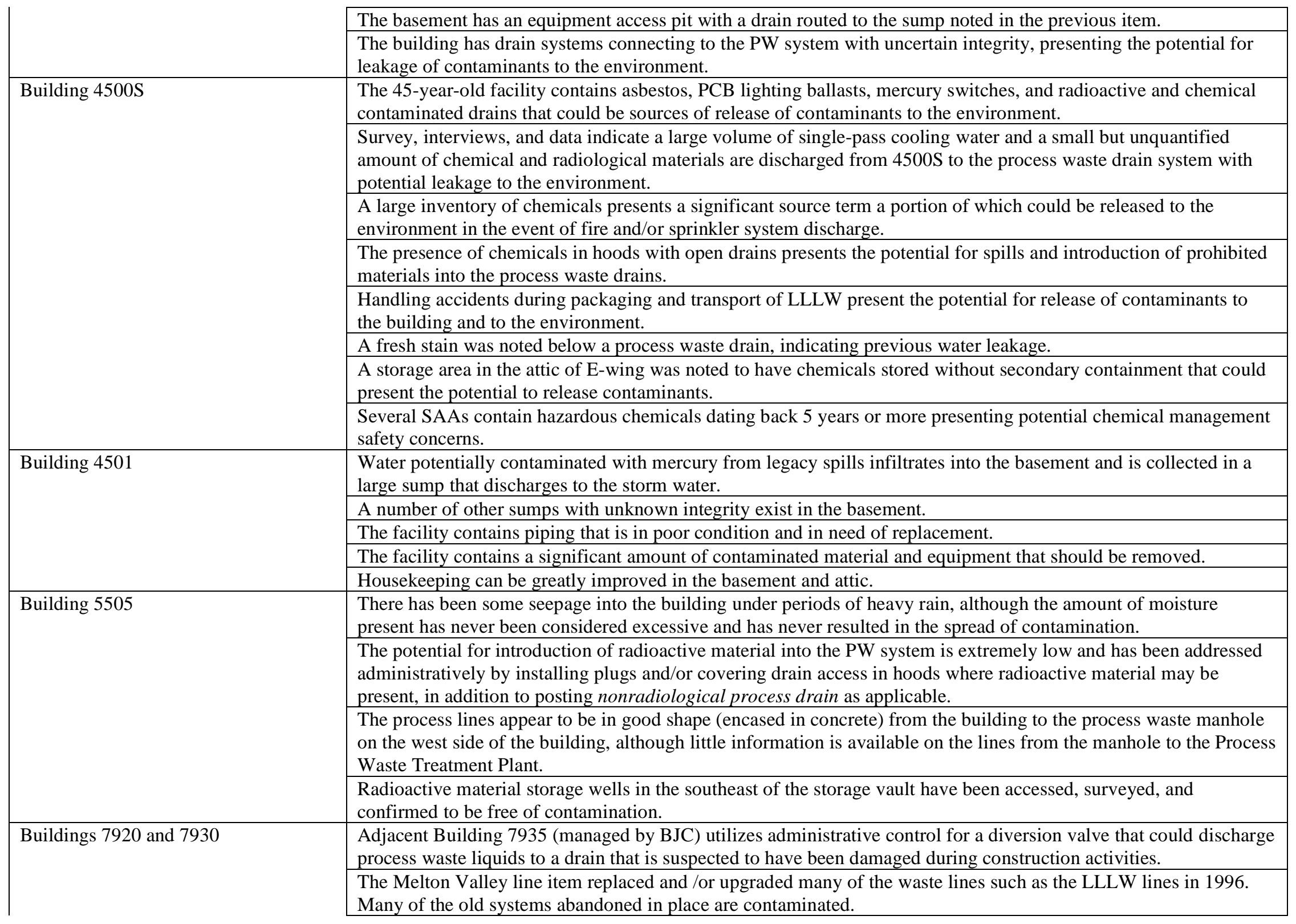




\begin{tabular}{|c|c|c|}
\hline & & One misrouted line was identified in Building 7920 and was immediately corrected. \\
\hline \multirow[t]{14}{*}{2.5 .2} & $\begin{array}{l}\text { Facilities with High Contamination } \\
\text { Areas } \\
\text { Buildings } 3091,3108,3121,3503 \text {, } \\
4505,4508,9204-3\end{array}$ & $\begin{array}{l}\text { All these facilities presented the vulnerability that contamination might be released to the environment through } \\
\text { unidentified leaks or in the event of off-normal conditions, such as high wind, earthquake, fire, or sprinkler } \\
\text { activation. }\end{array}$ \\
\hline & $\begin{array}{l}\text { Facilities with other than "Industrial/ } \\
\text { Generally Accepted" hazard rating } \\
\text { Buildings 3003, 6000, 6010, 9204-3 }\end{array}$ & No unusual vulnerabilities were identified at these facilities. \\
\hline & $\begin{array}{l}\text { Facilities that Require Hazards Surveys } \\
\text { and Assessments under DOE Order } \\
151.1 \text { Buildings } 2547,2643,6000 \\
6005,7040,7603\end{array}$ & $\begin{array}{l}\text { It was observed during the course of this review that a number of changes had occurred at these facilities that were } \\
\text { not reflected in the current documentation. }\end{array}$ \\
\hline & $\begin{array}{l}\text { Facilities that Discharge to the Central } \\
\text { Off-Gas System } \\
\text { Buildings } 3036,3121,3503,3508 \text {, } \\
3550,4500 N, 4505\end{array}$ & No unusual vulnerabilities were noted at any of these facilities. \\
\hline & $\begin{array}{l}\text { Facilities that Discharge to the ORNL } \\
\text { Liquid Waste System }\end{array}$ & Other than risks inherent in transport of liquids (i.e. potential for spills) no specific vulnerabilities were identified. \\
\hline & $\begin{array}{l}\text { Facilities Included in the ORNL Liquid } \\
\text { Generator List }\end{array}$ & No unusual vulnerabilities were noted. \\
\hline & $\begin{array}{l}\text { Facilities Connected to PW System as } \\
\text { Indicated on Drawings }\end{array}$ & No unusual vulnerabilities were noted. \\
\hline & \multirow[t]{4}{*}{$\begin{array}{l}\text { Facilities Connected to PW System as } \\
\text { Indicated in the Sink and Drain Survey }\end{array}$} & The only problems noted were several incorrectly labeled drains. \\
\hline & & $\begin{array}{l}\text { Review of the survey data indicates that quantitative process data - volumes and contaminant concentrations - are } \\
\text { not available for many of the generators who discharge to the PW system. }\end{array}$ \\
\hline & & $\begin{array}{l}\text { Detecting the resulting low contaminant concentrations makes environmental monitoring much more difficult, and } \\
\text { the increased water flow in potentially leaking pipes can contribute to the transport of subsurface contaminants. }\end{array}$ \\
\hline & & $\begin{array}{l}\text { While generators can satisfy current WAC through training and "process knowledge" the lack of quantitative } \\
\text { process information makes it impossible to demonstrate that UT-Battelle operations are not contributing to further } \\
\text { release of contaminants to the ORNL subsurface. }\end{array}$ \\
\hline & \multirow[t]{3}{*}{$\begin{array}{l}\text { Other Priority } 2 \text { facility vulnerabilities } \\
\text { identified }\end{array}$} & $\begin{array}{l}\text { PCB paint flaking has been occurring at } 2000 / 2001 \text { for several years. Actions have been undertaken to clean } \\
\text { adjacent storm catchments and drains to control paint chip migration while the transition of the facility to the DOE } \\
\text { EM Program is arranged. A potential regulatory vulnerability exists if this facility transfer is not executed. }\end{array}$ \\
\hline & & $\begin{array}{l}\text { An unlabeled lunchroom sink drain was noted in } 2500 \text { that was indicated on the Sink and Drain Survey as } \\
\text { "process." The drain was immediately labeled. }\end{array}$ \\
\hline & & $\begin{array}{l}\text { A residue was noted on the floor of the chemical storage room in } 2547 \text { around an apparently empty } 55 \text {-gal drum } \\
\text { with corrosion noted at the bottom. The material was immediately cleaned up. }\end{array}$ \\
\hline
\end{tabular}


Legacy Transition Project

Facility/ Site Characterization and Vulnerability Assessment

Drains labeled "process" were noted in 3502 that were indicated as "sanitary" in the Sink and Drain Survey. The drains were confirmed to be "sanitary" and relabeled immediately.

A hood in 3502 containing chemicals used to support manipulator boot manufacture had recently had vent modifications performed that were identified as potentially not in compliance with air permit requirements. It was confirmed with Environmental Compliance and Waste Services staff that the hood operation and vent were compliant.

Several questions on sinks and drains in 3587 were noted and forwarded to facility management for resolution. A large mercury spill in the 4501 basement during the 1950s leaked through cracks in the floor and into drains (that have since been sealed) and accumulated under the building and is presumably contributing to the known mercury leaks from this are to the storm drain system.

Other Facilities and Vulnerabilities

Historic airborne releases from off normal operations in the 1950s in Bethel Valley have resulted in localized radioactive contamination on building roofs, such as the cafeteria.

Historic airborne releases in Melton Valley, hypothesized to result from "dump and roll" waste disposal practices, have resulted in localized contamination in reservation areas maintained by UT-Battelle.

A damaged plastic liner is evident on the bank of the western sewage lagoon. While not a regulatory violation,

failure to repair the liner is not a best management practice.

Continued discharge of mercury to the storm water system from $4500 \mathrm{~S}$ and 3074 was noted.

Deteriorated beryllium-contaminated ductwork was identified at 3044.

The availability and restrictions on the use of "capital" funds encourages the continued "management" of

environmental vulnerabilities, such as use of single pass cooling, through use of overhead expense funding that may be more expensive in the long term.

ORNL does not currently have adequate capability to cleanup more than two workers who might become contaminated due to a spill. Up to two workers could be decontaminated at the Health Division but this operation could result in the contamination of currently clean areas.

Several hot cell facilities have windows containing zinc bromide that have not been replaced. These types of windows have historically been prone to leaks due to the corrosive nature of the zinc bromide.

A number of ORNL facilities rely on the Central Off Gas system operated by BJC to maintain negative pressure in contaminated areas. While there have not historically been problems with maintaining the system negative pressure, there have been instances where localized loss of negative pressure has been experienced. 


\section{ORNL/TM-2001/123}

\section{INTERNAL DISTRIBUTION}

1. G. E. Anderson

2. K. J. Beierschmitt

3. T. M. Bonine

4. W. K. Brown

5. N. S. Dailey

6. H. L. Debban

7. K. M. Downer

8. H. R. Fair

9. G. F. Flanagan

10. A. F. Frederick

11. R. G. Gilliland

12. J. C. Glowienka

13. W. D. Goddard

14. S. A. Hamley

15. W. F. Harris

16. C. T. Higdon

17. P. B. Hoke

18. J. B. Hunt

19. J. E. Lee

20. W. J. Madia

21. G. J. Malosh

22. A. R. Medley

23. C. D. Melbihess

\author{
24. L. J. Mezga \\ 25. D. Milan \\ 26. W. H. Miller \\ 27. T. E. Myrick \\ 28. J. O. Moore \\ 29. B. D. Patton \\ 30. L. L. Riedinger \\ 31. J. B. Roberto \\ 32. L. C. Roddye \\ 33. G. E. Rothenberger \\ 34. C. H. Scott \\ 35. D. D. Skipper \\ 36. J. W. Smith \\ 37. R. M. Stinnett \\ 38. J. H. Swanks \\ 39. C. K. Valentine \\ 40. S. D. Van Hoesen \\ 41. H. R. Vogel \\ 42. J. M. Wolfe \\ 43. Central Research Library \\ 44. ORNL Laboratory Records-OSTI \\ 45. ORNL Laboratory Records-RC
}

\section{EXTERNAL DISTRIBUTION}

46. J. G. Burr, Pacific Northwest National Laboratory, P. O. Box 999, 902 Battelle Blvd., Richland, Washington 99352

47. K. W. Cook, Bechtel Jacobs Company, LLC, P. O. Box 2008, Oak Ridge, TN 37831-6402

48. G. R. Eidam, Bechtel Jacobs Company, LLC, P. O. Box 2008, Oak Ridge, TN 37831-6402

49. C. E. Frye, Bechtel Jacobs Company, LLC, P. O. Box 2008, Oak Ridge, TN 37831-7119

50. R. H. Ketelle, Bechtel Jacobs Company, LLC, P. O. Box 2008, Oak Ridge, TN 37831-6402

51. M. J. Lauterbach, Bechtel Jacobs Company, LLC, P. O. Box 2008, Oak Ridge, TN 37831-6028

52. J. R. Lyons, Bechtel Jacobs Company, LLC, P. O. Box 2008, Oak Ridge, TN 37831-7294

53. J. J. Maddox, Bechtel Jacobs Company, LLC, P. O. Box 2008, Oak Ridge, TN 37831-6058

54. T. G. Naymik, Battelle Memorial Institute, 505 King Ave., Columbus, OH 43201

55. M. R. Peet, Bechtel Jacobs Company, LLC, P. O. Box 2008, Oak Ridge, TN 37831-6028

56. C. B. Scott, Bechtel Jacobs Company, LLC, P. O. Box 2008, Oak Ridge, TN 37831-6058

57. M. L. West, Bechtel Jacobs Company, LLC, P. O. Box 2008, Oak Ridge, TN 37831-7123 